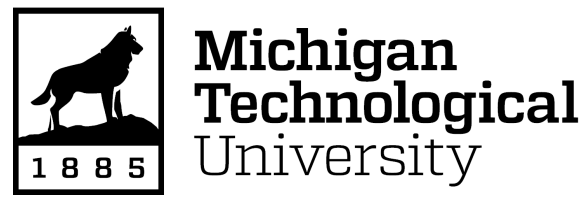

Michigan Technological University Digital Commons @ Michigan Tech

Dissertations, Master's Theses and Master's Reports

2020

\title{
THE INFLUENCE OF LANDFORMS AND SAMPLING APPROACHES ON RIPARIAN BUFFER AREA AND COMPLEXITY
}

Houjun Ding

Michigan Technological University, houjund@mtu.edu

Copyright 2020 Houjun Ding

Recommended Citation

Ding, Houjun, "THE INFLUENCE OF LANDFORMS AND SAMPLING APPROACHES ON RIPARIAN BUFFER

AREA AND COMPLEXITY", Open Access Dissertation, Michigan Technological University, 2020.

https://doi.org/10.37099/mtu.dc.etdr/992

Follow this and additional works at: https://digitalcommons.mtu.edu/etdr

Part of the Forest Management Commons, Geographic Information Sciences Commons, and the Spatial Science Commons 
THE INFLUENCE OF LANDFORMS AND SAMPLING APPROACHES ON RIPARIAN BUFFER AREA AND COMPLEXITY

\author{
By \\ Houjun Ding
}

\begin{abstract}
A DISSERTATION
Submitted in partial fulfillment of the requirements for the degree of DOCTOR OF PHILOSOPHY

In Forest Science
\end{abstract}

MICHIGAN TECHNOLOGICAL UNIVERSITY

2020

(C) 2020 Houjun Ding 
This dissertation has been approved in partial fulfillment of the requirements for the Degree of DOCTOR OF PHILOSOPHY in Forest Science.

College of Forest Resources and Environmental Science

Dissertation Advisor: Ann L. Maclean

Committee Member: Curtis B. Edson

Committee Member: Joseph W. Wagenbrenner

Committee Member: $\quad$ Sinan A. Abood

College Dean: $\quad$ Andrew J. Storer 


\section{Table of Contents}

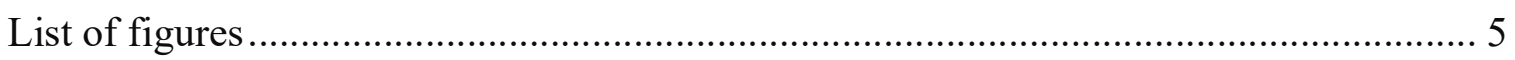

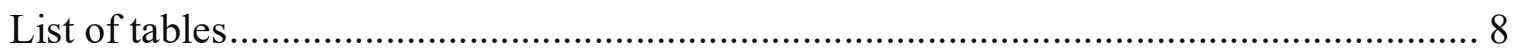

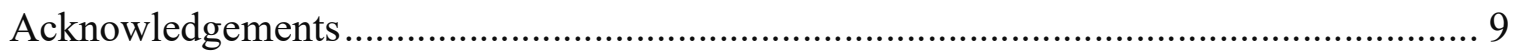

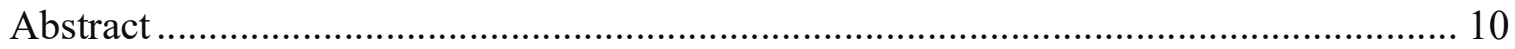

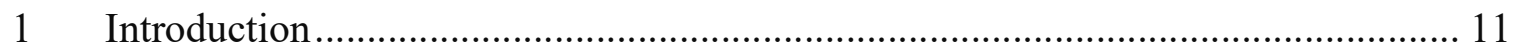

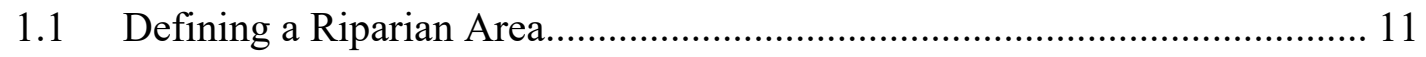

1.2 Riparian Buffer Delineation Model Background ......................................... 12

1.3 Scope of the Research ......................................................................... 14

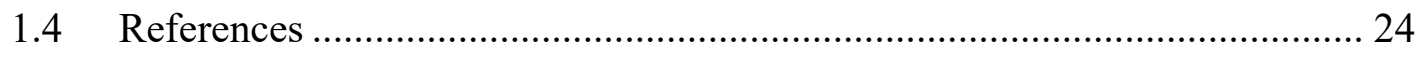

2 The Influence of Geomorphic Landform on Riparian Management Zones ............ 27

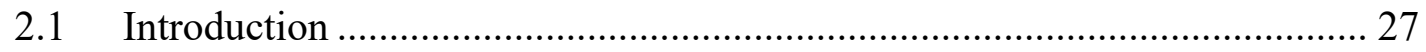

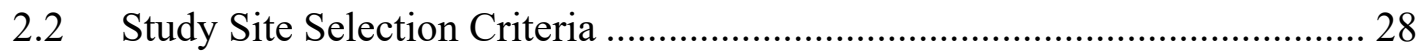

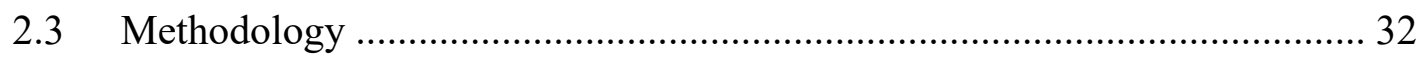

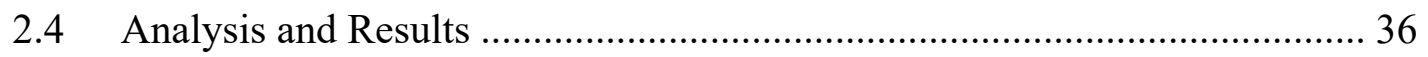

2.4.1 Extent Parameters ......................................................................... 36

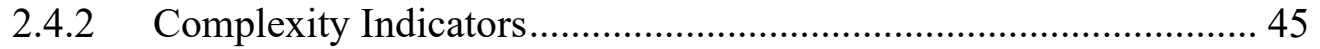

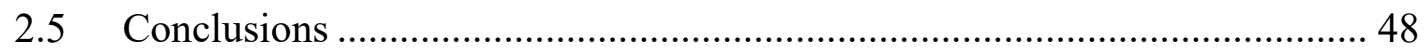

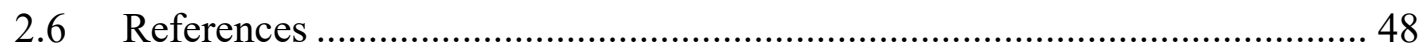

3 Analysis of Distance Sampling Approaches on Riparian Buffer Area and

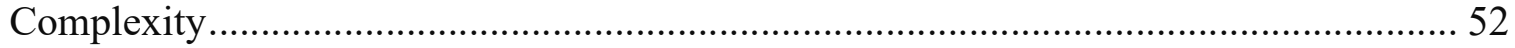

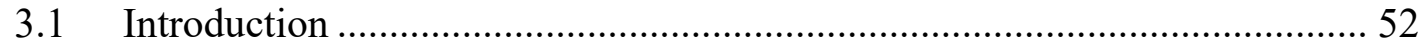

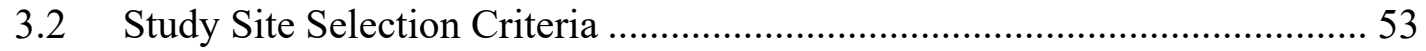

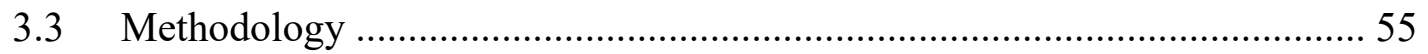

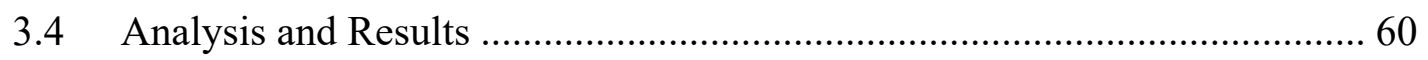

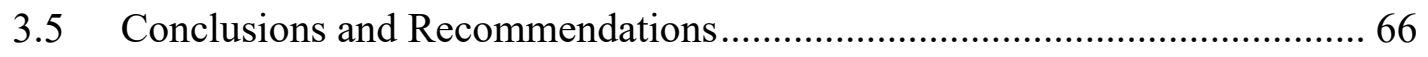

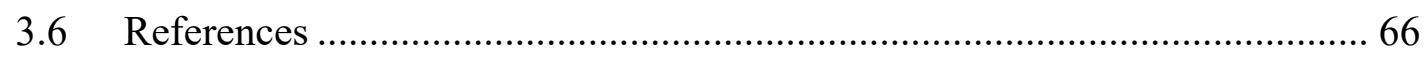




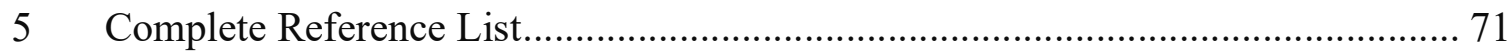

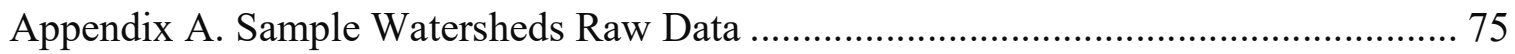

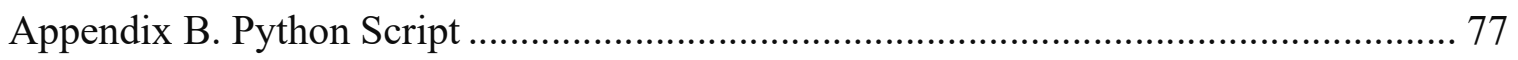

Appendix C. Parameters under different spatial resolutions ...................................... 85

C.1 The parameters when using 10-m DEMs ................................................ 85

C.2 The parameters when using 5-m DEMs................................................ 86

C.3 The parameters when using 1-m DEMs................................................ 87 


\section{List of figures}

Figure 1.1. Riparian area in Cass County, Minnesota. June 6, 2018.............................. 12

Figure 1.2. Laurentian Mixed Forest extent in the Upper Midwest used in study site selection. Data source: United States Department of Agriculture Forest Service and US Census Bureau. Coordinate system: USA Contiguous Albers Equal Area Conic.

Figure 1.3. Surficial landform types for northeast Minnesota within the LMF Province. Data source: Minnesota Department of Natural Resources and USGS National Hydrography Dataset. Coordinate system: NAD 1983 UTM Zone 15N.

Figure 1.4. Satellite image of supraglacial drift complex within the study site. Image source: Google Earth, earth.google.com/web/.

Figure 1.5. Satellite image of igneous within the study site. Image source: Google Earth, earth.google.com/web/.

Figure 1.6. Satellite image of metamorphic within the study site. Image source: Google Earth, earth.google.com/web/.

Figure 1.7. Satellite image of outwash within the study site. Image source: Google Earth, earth.google.com $/ \mathrm{web} /$.

Figure 1.8. Satellite image of peatland within the study site. Image source: Google Earth, earth.google.com/web/.

Figure 1.9. Satellite image of till plain within the study site. Image source: Google Earth, earth.google.com/web/.

Figure 2.1. Laurentian Mixed Forest extent in the Upper Midwest used in study site selection. Data source: United States Department of Agriculture Forest Service and US Census Bureau. Coordinate system: USA Contiguous Albers Equal Area Conic.

Figure 2.2. Surficial landform types for northeast Minnesota within the LMF Province. Data source: Minnesota Department of Natural Resources and USGS National Hydrography Dataset. Coordinate system: NAD 1983 UTM Zone 15N.............. 30

Figure 2.3. Watershed locations selected for the study overlaid on the landform types. Data source: Minnesota Department of Natural Resources and USGS National Hydrography Dataset. Coordinate system: NAD 1983 UTM Zone 15N 
Figure 2.4. Locations of the stream gauges in the study site. Data source: Minnesota Department of Natural Resources and USGS Water Data. Coordinate system: NAD 1983 UTM Zone 15N.

Figure 2.5. Flood height regression plot for the outwash landform 33

Figure 2.6. Illustration between locations of digitized stream channels and original NHD flow lines.

Figure 2.7. Workflow for digitizing improved stream channel locations from 1-meter DEMs using Arc Hydro tools.

Figure 2.8. Basic riparian area vs. watershed area (A) and inclusive riparian area vs. watershed area (B) regardless of landform. Points within the box indicate potential outliers.

Figure 2.9. Basic riparian area vs. total stream length $(\mathrm{A})$ and inclusive riparian area vs. total stream length (B) regardless of landform. Points within the box indicate potential outliers.

Figure 2.10. Example of basic and inclusive riparian areas in a peatland watershed (Headwaters Little Fork River).

Figure 2.11. Example of basic and inclusive riparian areas in an outwash watershed (Big Deep Lake-Boy River). 42

Figure 2.12. Example of basic and inclusive riparian areas in a supraglacial drift complex watershed (Wagner Creek).

Figure 2.13. Example of basic and inclusive riparian areas in an igneous landform watershed (Boulder River).

Figure 2.14. Example of basic and inclusive riparian areas in a till plain watershed (South Branch Whiteface River).

Figure 3.1. Side view of surface runoff with sample points at a regular, planar coordinate interval, comparing to varying ground distances due to slope. 53

Figure 3.2. Surficial landform types for northeast Minnesota within the LMF Province. Data source: Minnesota Department of Natural Resources and USGS National Hydrography Dataset. Coordinate system: NAD 1983 UTM Zone 15N

Figure 3.3. Locations of the stream gauges in the study site. Data source: Minnesota Department of Natural Resources and USGS Water Data. Coordinate system: NAD 1983 UTM Zone 15N. 
Figure 3.4. Example of flood height regression plots for the outwash landform. 56

Figure 3.5. Locations of digitized stream channels and original NHD flow lines. 57

Figure 3.6. Workflow for digitizing improved stream channel locations from 1-meter DEMs using Arc Hydro tools. 58

Figure 3.7. Calculated point sample locations generated along the stream................... 59

Figure 3.8. Side view of the triangular relation between adjacent points V1 and V2 ..... 60

Figure 3.9. Equal interval ground distance sample points locations versus the planar sample points generated from a 10-m DEM.................................................. 61

Figure 3.10. Riparian area classified by stream order excluding lake buffers. 63

Figure 3.11. Riparian areas generated by 5-meter DEMs using both planar and equal interval ground distance sampling methods.

Figure 3.12. Difference between riparian area outputs between planar coordinate and ground distance sampling methods. 65 


\section{List of tables}

Table 1.1. Riparian Buffer Delineation Model (RBDM) Inputs and Sources. ................. 14

Table 2.1. Flood heights for various stream orders within the outwash landform. ......... 33

Table 2.2. $\mathrm{R}^{2}$ and RSE between watershed area and riparian area (basic and inclusive), and the relationship between total stream length and riparian area (basic and inclusive) regardless of landform.............................................................. 38

Table 2.3. $\mathrm{R}^{2}$ and RSE between watershed area and riparian area (basic and inclusive) for each landform types. Watersheds contained within the metamorphic landform are eliminated due to small sample size $(\mathrm{n}=2)$

Table 2.4. $\mathrm{R}^{2}$ and RSE between total stream length and riparian area for each landform types. Watersheds contained within the metamorphic landform are eliminated due to small sample size $(n=2)$.

Table 2.5. Mean RW and mean RS for each landform. Watersheds contained within the metamorphic landform are eliminated due to small sample size $(n=2)$

Table 2.6. Mean values of the complexity indicators vs. landform types. 46

Table 3.1. Example of flood heights for various stream orders for the outwash landform. 


\section{Acknowledgements}

"If I have seen further than others, it is by standing upon the shoulders of giants."

- Isaac Newton

I would like to express my sincere gratitude to my advisor Dr. Ann Maclean, who has been teaching and mentoring me since 2014 . Her guidance proved monumental towards the success of this project and making it a reality. More importantly, over the past five years, I've seen patience, tolerance, and faith on her, no matter what the circumstances are. Her spirit will keep inspiring me in the future.

I am also grateful to my committee members for providing wonderful lectures and learning opportunities, which enriched my knowledge and broadened my horizons. I wish to pay my special regards to Dr. Sinan Abood, who is not only the author of the Riparian Buffer Delineation Model, but also tremendously helpful for improving my programming skills. I would also like to thank our Dean Dr. Andrew J. Storer, who has done a great job of caring for everyone in the college and making the effort to provide a better learning environment.

Last but not the least, I am thankful to my parents, and my wife Yanyun, who always encourage me throughout the year. Life is never easy. It is full of ups and downs, and I would never make it without your support and love. My heartfelt thanks. 


\section{Abstract}

A riparian area is a zone of interaction between aquatic and terrestrial ecosystems. Delineating accurate riparian management zones (RMZs), often utilized in Best Management Practices (BMPs) for wetlands and stream protection, is important. The Riparian Buffer Delineation Model (RBDM) has been used extensively for accurate RMZs delineation. Utilizing the validated RBDM generates additional questions about riparian area form and function, which will ideally lead to an improved understanding of the ecological process within these zones. This study aims to determine how geomorphic landforms and their associated landscape characteristics influence riparian areas in terms of shape and complexity, whether sampling methods of the RBDM (ground distance vs. horizontal distance) along the water course impact the extent and complexity of the riparian area, and how spatial resolution of DEM influence riparian area delineation using different sampling methods.

Based on the geomorphology of Province 212 (Laurentian Mixed Forest Province, or LMF Province), the portion located in Minnesota are chosen as the study site. In Chapter 2 , sample watersheds and the 50-year flood heights are categorized by landform types, and new stream data are generated using the Arc Hydro tools. By integrating these data with other inputs, both basic and inclusive riparian areas on each landform are generated using the RBDM. Extent parameters and complexity indicators, such as edge density, total edge and mean shape index, of the buffers are calculated using Patch Analyst and analyzed for each landform type. The results provide an analytical perspective of the RMZs' delineation and geomorphic landforms do impact the size and shape of riparian areas. In Chapter 3, a new sampling approach is introduced- equal interval ground distance. This method compared to the traditional approach of using planar coordinates (horizontal distance) for sampling is incorporated in the RBDM via a Python script. A comparison between the two sampling methods is conducted for each landform type using 1, 5, and 10-meter DEMs. The results indicate the ground distance sampling method delineates more accurate riparian buffer boundaries with 1-meter DEMS. However, the boundary differences when using 5 and 10-meter DEMs are negligible. 


\section{Introduction}

\subsection{Defining a Riparian Area}

A riparian area is a zone of interaction between aquatic and terrestrial ecosystems along streams, lakes, wetlands, and other water bodies. Riparian areas influence water bodies and are also influenced by them. They perform important ecological functions that link aquatic and terrestrial ecosystems (Riparian Science Technical Committee MN, 2007). Delineating accurate riparian management zones (RMZs), often utilized in Best Management Practices (BMPs) for wetlands and stream protection, is important. These zones effectively moderate microclimate at the local ecosystem scale, and trap sediments and nutrients between waterbodies and uplands. In this way, multiple conservation goals are achieved, such as stream stabilization, flood attenuation, and providing habitat for a wide variety of flora and fauna.

There is no single, widely accepted definition for a riparian area (zone or ecosystem) (Abood, 2011). A riparian zone is inclusive of hydrophytes and/or soil saturated by ground water for at least part of the growing season within the rooting depth of native vegetation (Cowardin et al., 1979). The zone is often expanded to include adjacent lands with a moderate or a well-balanced supply of moisture (Mitsch and Gosselink, 1993). These researchers further specify three properties to distinguish riparian ecosystems:

- Riparian ecosystems generally have a linear form because of their proximity to rivers and streams;

- Energy and material from the surrounding landscape pass through riparian ecosystems in greater amounts than those of other wetland ecosystems; and

- Riparian ecosystems are functionally connected to upstream and downstream ecosystems as well as to contiguous uplands and aquatic systems.

For this research, Ilhardt et al., (2000) definition of a riparian buffer is utilized. They defined a riparian buffer as a three-dimensional space of interactions that includes terrestrial and aquatic ecosystems extending downward into the groundwater table, upward to include the canopy, outward across the floodplain, up near-slopes, and along the water course at a variable width. It is also important to remember riparian area boundaries are often defined by their vegetation communities (Figure 1.1). 


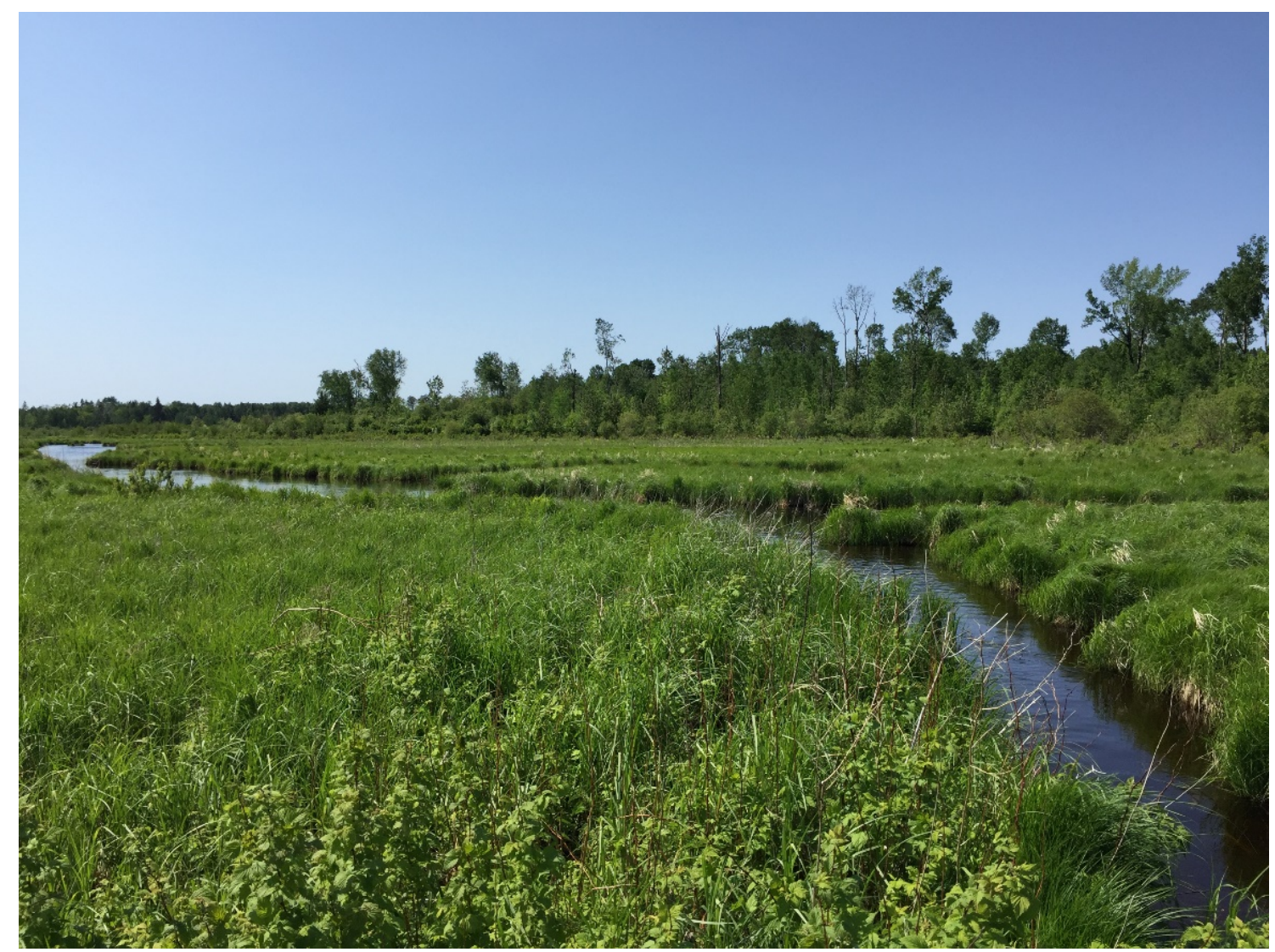

Figure 1.1. Riparian area in Cass County, Minnesota. June 6, 2018.

\subsection{Riparian Buffer Delineation Model Background}

Fixed width buffers, which are simple to delineate, implement and monitor, were regarded as the standard practice for many years to protect waterbodies from adverse impacts of development, timber harvesting and agricultural runoff. Before the commercialization and widespread use of Global Information System (GIS), a fixed width buffer was the easiest to map on the ground. However, Palik et al. (2000) showed the fixed width buffer riparian delineation approach was inadequate and inaccurate as these buffers cannot replicate natural riparian zone boundaries, since they have no functional relationship to the naturally varying watercourse and its associated land cover. In addition, research conducted by Skally and Sagor (2001) within northern Minnesota concluded riparian buffer boundaries were, on average, 2.5 times farther from the water body than the recommended fixed width buffer. Additional research by Macdonald et al. (2003) and Hanowski et al. (2007) supported these conclusions.

In developing a variable width RMZ delineation model, two factors that all riparian zones have in common are the watercourse and its associated floodplain, and these two 
components must be included in any delineation model. Research by Ilhardt et al. (2000) determined the 50-year floodplain was the optimal hydrologic descriptor of a RMZ. By hydrologically defining a RMZ as occurring at the 50-year flood height and incorporating digital elevation data (DEM) with the spatial modeling capabilities of ArcGIS software, the Riparian Buffer Delineation Model (RBDM) was developed and implemented (Mason, 2007; Abood et al., 2012). The RBDM has been used extensively by various government agencies, NGOs, academic programs, private companies, and individuals. It has undergone rigorous validation for accurate boundary delineation (Abood et al., 2018).

Applying the flood height algorithm developed by Mason (2007), allows the RBDM to utilize the nationwide USGS Water Data. The USGS Water Data for the Nation site (USGS, 2017) provides stream gauge data for calculating flood heights. Current conditions at the gauges are measured by on-site automated recording equipment. Measurements are commonly recorded at a fixed interval of 15 to 60 minutes and transmitted to the USGS every hour via telecommunications satellite. Manual field measurements and annual statistics are used to calculate 50-year flood heights. Field measurements include streamflow and gauge height and are used to supplement and/or verify the accuracy of the automatically recorded observations, as well as compute streamflow based on gauge height. Annual statistics are computed from verified daily mean data from each gauge. Summaries of historical daily values for annual periods are maintained as well.

To facilitate use of the RBDM, the developers utilize spatial data readily available from government agencies and geospatial data clearinghouses (Table 1.1). The NHD (National Hydrography Dataset) is a vector-based dataset formatted as an ArcGIS File Geodatabase (FGDB or GDB), which provides spatial information on watershed boundaries, flow lines (streams and rivers) and waterbodies (lakes and reservoirs). It contains surface water components information, derived from established stream orders, and is compatible with stream gauge records (discussed in previous paragraph) from various locations along the stream channel.

Further model development incorporated the US Fish and Wildlife Service (USFWS) National Wetlands Inventory (NWI), and the Natural Resource Conservation Service (NRCS) Gridded Soil Survey Database (gSSURGO) to improve the delineation of riparian areas. NWI is a nationwide inventory of wetlands, maintained by the USFWS and provides information on the distribution and classification of wetlands. The gSSURGO data consists of soil mapping units created from field point samples interpolated by soil scientists at NRCS and is also in GDB format. It was used instead of the SSURGO data, due to the finer spatial resolutions, better edge matching, and the information provided in the new potential wetland soils table. Data sources for the model inputs for this research are listed in Table 1.1. Other details on RBDM functionality are found in Abood and Maclean (2012). 
Table 1.1. Riparian Buffer Delineation Model (RBDM) Inputs and Sources.

\begin{tabular}{ll}
\hline Input Data & Source \\
Watersheds and & $\begin{array}{l}\text { USGS National Hydrography Dataset } \\
\text { http:// nhd.usgs.gov/index.html }\end{array}$ \\
\hline 1-meter LiDAR DEMs & $\begin{array}{l}\text { Minnesota Geospatial Information Office } \\
\text { http://www.mngeo.state.mn.us/chouse/elevation/li } \\
\text { dar.html }\end{array}$ \\
\hline Stream gauge data & $\begin{array}{l}\text { USGS Water Data for USA } \\
\text { https://waterdata.usgs.gov/nwis }\end{array}$ \\
\hline Wetlands & $\begin{array}{l}\text { National Wetlands Inventory } \\
\text { https://www.fws.gov/wetlands/ }\end{array}$ \\
\hline Soils & $\begin{array}{l}\text { Gridded Soil Survey Database (gSSURGO) } \\
\text { https://www.nrcs.usda.gov/wps/portal/nrcs/detail/t }\end{array}$ \\
& $\underline{\text { x/home/?cid=nrcs142p2 053628 }}$
\end{tabular}

\subsection{Scope of the Research}

Utilizing the RBDM generates additional questions about riparian area form and function. Answers to these questions will ideally lead to an improved understanding of the ecological processes within the RMZs. A key question is does geomorphology or landform influence riparian area extent and shape complexity? A review of the literature reveals this has not been researched and evaluated. Hence the influence of geomorphic landforms on the extent and complexity of riparian areas is not well understood. Different geomorphic processes create distinct landforms during long geologic periods, such as cooling and consequent solidification of magma, consolidation of sediments, glaciation and actions on preexisting sediments or rocks, such as weathering, pressure and heat. These landform development processes create multiple land surface characteristics which, in turn, influence topography, soils, and erosion characteristics. Therefore, the initial hypothesis or question for this research is: Do landforms and their associated characteristics influence the overall extent and complexity of riparian areas? Landform characteristics include stream drainage patterns, presence of adjacent wetlands and soil drainage characteristics are considered in the analysis. Selection of the study site is guided, in part, by this question.

The complex and multiple glaciations which took place in the Upper Midwest do not exist elsewhere in the United States and provide a unique look at a diversity of landforms within a relatively small geographic area. Ideally, the study area should be a contiguous area of different landforms, which has been minimally impacted by resource development, urbanization and other anthropogenic activities. These activities often introduce large areas of impervious surfaces and destroy riparian areas and wetlands. 
In addition, the area must have standardized, consistent, high quality spatial data which are required by the RBDM model. Data with an assessment of positional errors is preferred since these carry through to the location of riparian boundaries. Finer spatial resolution data is desirable to map detailed changes across different landforms. There also needs to be an adequate number and good distribution of stream gauges across the area. Previous studies have shown this to be the most difficult data requirement to achieve (Abood and Maclean, 2018), and gauges outside of a watershed may need to be utilized.

To minimize climate influences, a decision was made to utilize Ecological Provinces as the first step in study site selection. Ecological Provinces are units of land delineated using major climate zones, similar soil orders, native vegetation and biomes. At the ecoregion scale, the basic assumption is that climate governs energy and moisture gradients, thereby acting as the primary control over more localized ecosystems (Cleland et al., 1997). External environmental factors throughout the whole area are similar. For example, significant differences in temperature or precipitation from north to south are minimized. The northern one third of Wisconsin, Michigan's Upper Peninsula and northern half of the Lower Peninsula, and the northeastern two thirds of Minnesota are in Ecological Province 212 (Laurentian Mixed Forest Province, or LMF Province) (Figure 1.2). This area is dominated by native forests, wetlands and open meadows with little urban development and industrialization.

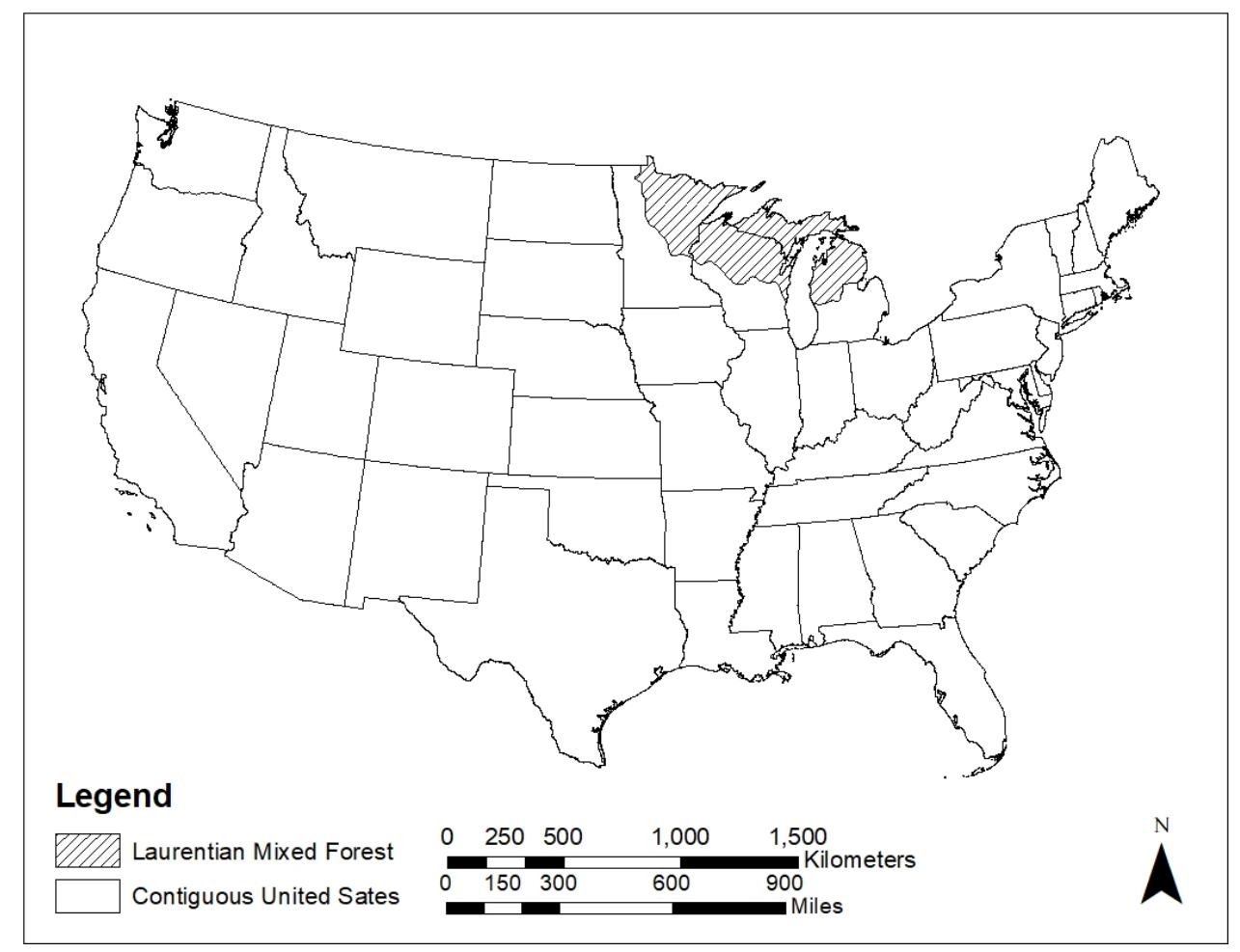

Figure 1.2. Laurentian Mixed Forest extent in the Upper Midwest used in study site selection. Data source: United States Department of Agriculture Forest Service and US Census Bureau. Coordinate system: USA Contiguous Albers Equal Area Conic. 
In Minnesota, the LMF Province is characterized by broad areas of conifer forest, mixed hardwood and conifer forests, and conifer bogs and swamps. The landscape varies from rugged lake-dotted terrain with thin glacial deposits over bedrock, hummocky or undulating plains with deep glacial drift, and large, flat, poorly drained peatlands. Precipitation ranges from $53 \mathrm{~cm}$ (21 in) annually along the western border of the Province to $81 \mathrm{~cm}$ (32 in) in northeastern Minnesota. Annual average temperatures are $1{ }^{\circ} \mathrm{C}\left(34^{\circ} \mathrm{F}\right)$ along the northern part of the Province in Minnesota, rising to $4^{\circ} \mathrm{C}\left(40^{\circ} \mathrm{F}\right)$ at its southern boundary (Minnesota Department of Natural Resources, 2016). With these similarities, climatic factors that significantly contribute to the extent and complexity of the riparian areas are minimized.

During the timeframe of this study, the State of Minnesota was in the process of remapping the State's wetlands. Part of the process involved acquisition of 1-meter LiDAR derived DEMS and refinement of the SSURGO soils maps and creation of gSSURGO soils data at a $10 \mathrm{~m}$ spatial resolution. DEMs with a high spatial resolution are essential to detect subtle elevation changes along stream courses within the riparian areas, particularly in peatlands. When the research was started in 2016, only the Minnesota Geospatial Information Office had 1-meter LiDAR derived DEMs within Province 212. The wetland boundaries in Minnesota were in part derived from these DEMs as part of the wetlands mapping update completed by the Minnesota Department of Natural Resources.

Within Province 212, the distribution of landforms was considered along with the availability of associated spatial data required by the RBDM. The landforms being evaluated need to be homogeneous with a large spatial extent, rather than small scattered areas or intermixed landforms. Additionally, watersheds need to be wholly contained within a single landform. Based on the geomorphology of Province 212 and the availability of high-quality spatial data, the portion of the province located in Minnesota was selected.

Additionally, the 1:100,000 Geomorphology of Minnesota map (Thomas, 2014), describes a wide variety of conditions related to surficial geology within a hierarchical classification scheme. It contains multiple dominant surficial landforms, and some lesser landforms (Figure 1.3). While this dataset is at a coarser scale than the other inputs, it does provide the required landform boundaries. When overlaid on finer scale data, the boundaries were refined and updated as needed.

Six landforms, representing the dominant formation characteristics for the province are utilized for the study, including:

- Supraglacial Drift Complex

- Igneous

- Metamorphic

- Outwash

- Peatland 
- Till Plain

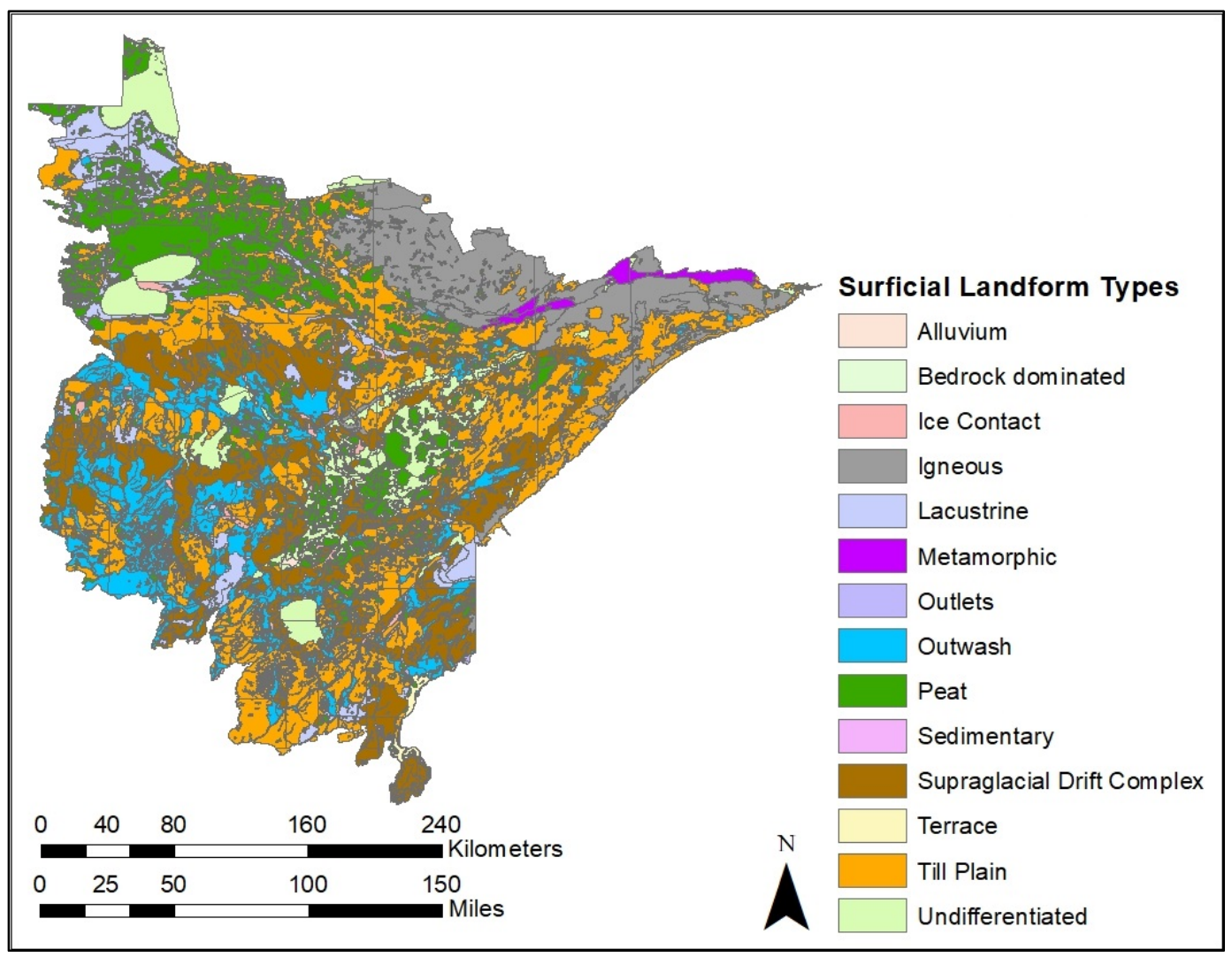

Figure 1.3. Surficial landform types for northeast Minnesota within the LMF Province. Data source: Minnesota Department of Natural Resources and USGS National Hydrography Dataset. Coordinate system: NAD 1983 UTM Zone 15N.

A supraglacial drift complex landform is composed of coarsely graded and complex glacial sediments (Figure1.4). Soils in this region were formed in glacial deposits from the Wisconsin glacier (14,000 to 24,000 years ago). They were made mainly from sandstone, shale and small amounts of limestone, which are low in organic matter, and acidic. The topography is gently rolling with some steep slopes, and erosion can be a problem (Peacefull et al, 1996). 


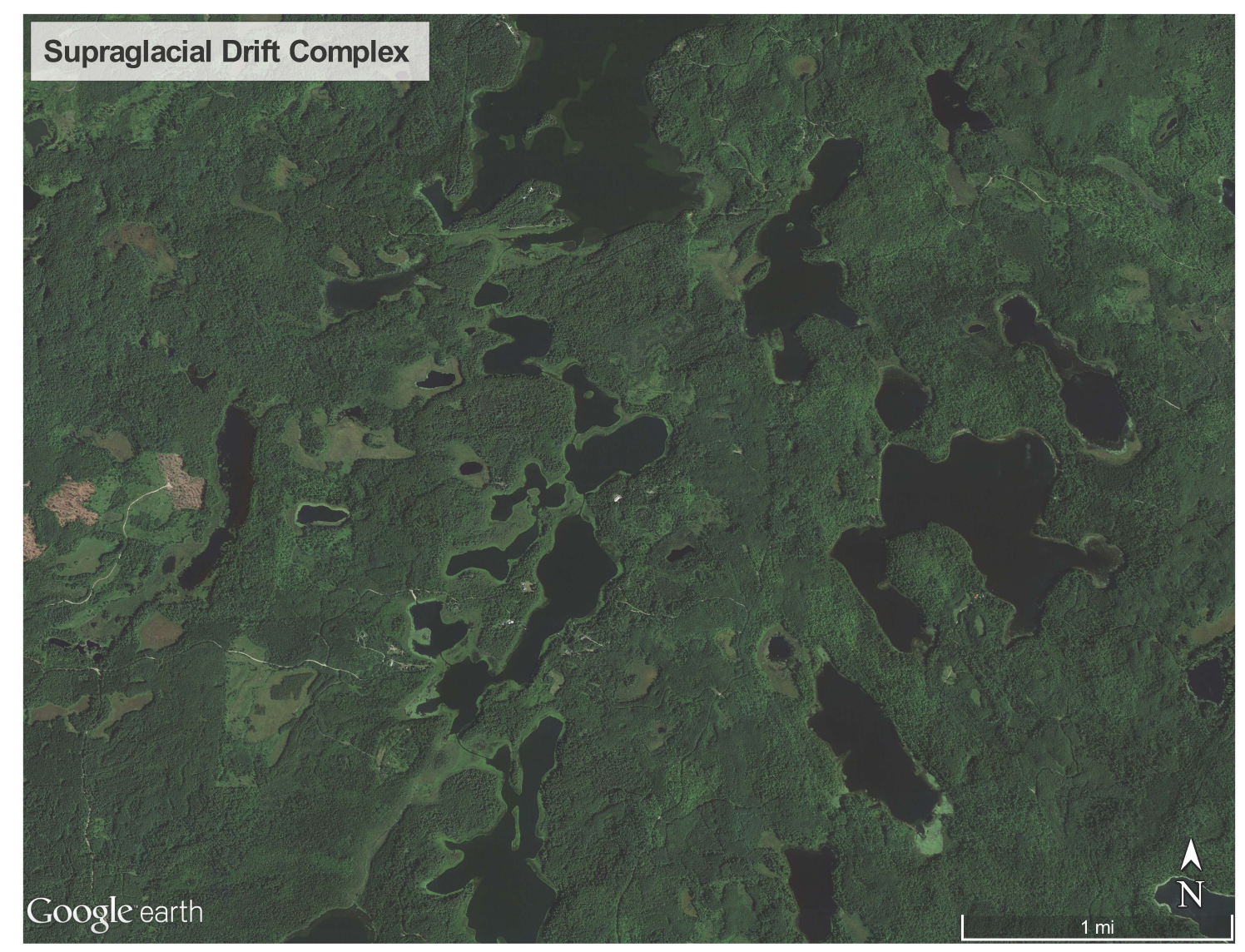

Figure 1.4. Satellite image of supraglacial drift complex within the study site. Image source: Google Earth, earth.google.com/web/.

An igneous landform is formed from cooling and consequent solidification of magma (Figure 1.5). These massive batholithic instructions are topographically expressed as domelike hills in general. In humid or temperate regions, the tops of the hills are gently rounded, and the side slopes are relatively steep, producing a "knobby" topography. Dendritic (treelike) drainage patterns tend to develop. In areas where extensive jointing has occurred, rectangular drainage patterns may develop (Integrated Publishing, 2003). 


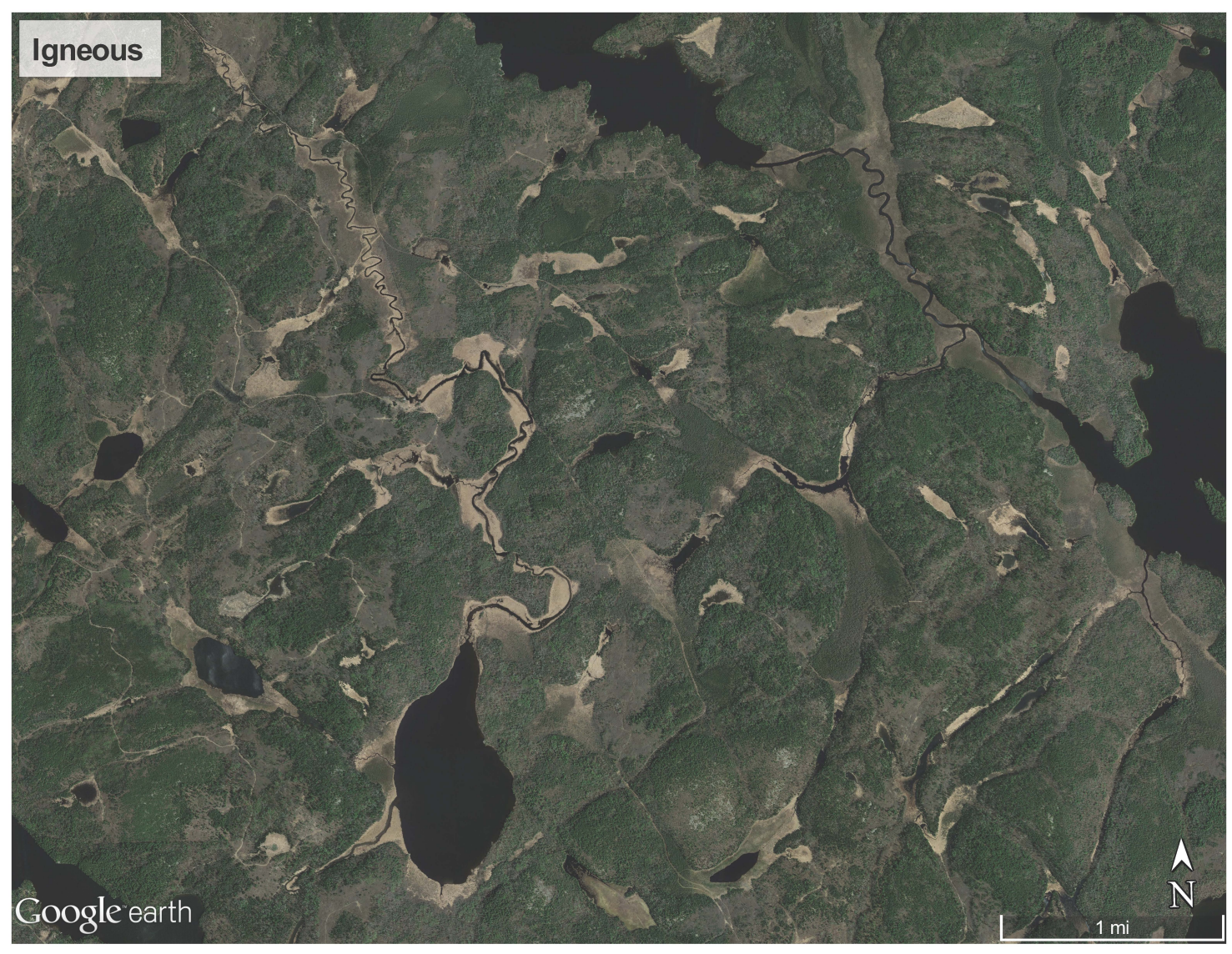

Figure 1.5. Satellite image of igneous within the study site. Image source: Google Earth, earth.google.com/web/.

Metamorphic landforms are created from the transformation of underlying rocks subjected to high temperatures and pressures (Figure 1.6). The rocks produce a very rugged, highly dissected topography with sharp parallel ridges and steep side slopes. Hilltops are relatively low but of approximately equal elevation (Hoffman and Bowring, 1984). 


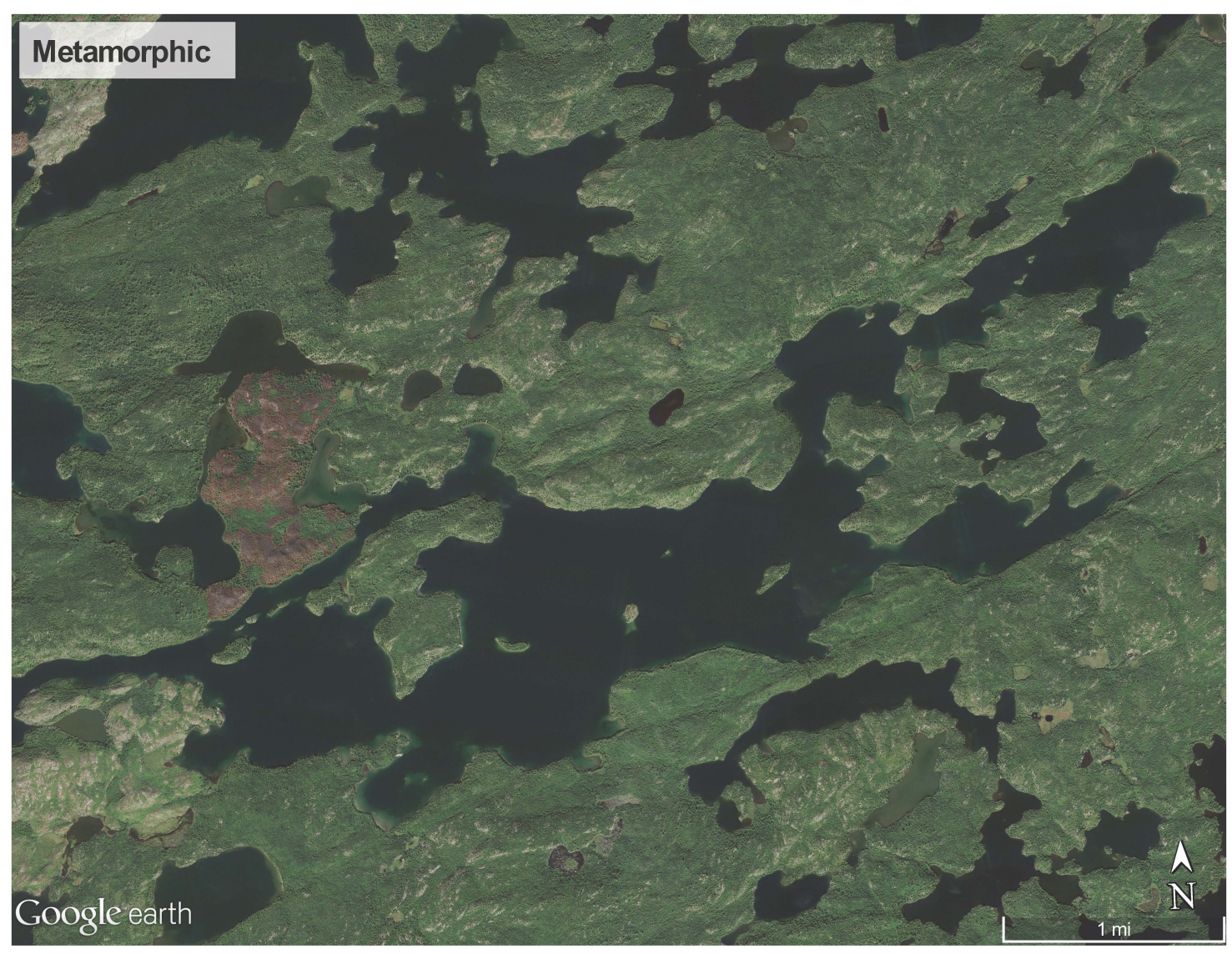

Figure 1.6. Satellite image of metamorphic within the study site. Image source: Google Earth, earth.google.com/web/.

An outwash landform is formed from glacier sediments deposited by meltwater at the terminus of a glacier. Streams running off the end of a melting glacier are usually choked with sediment and form braided streams, which deposit poorly sorted stratified sediment (Figure 1.7). It is usually associated with a broad, gently sloping plain. 


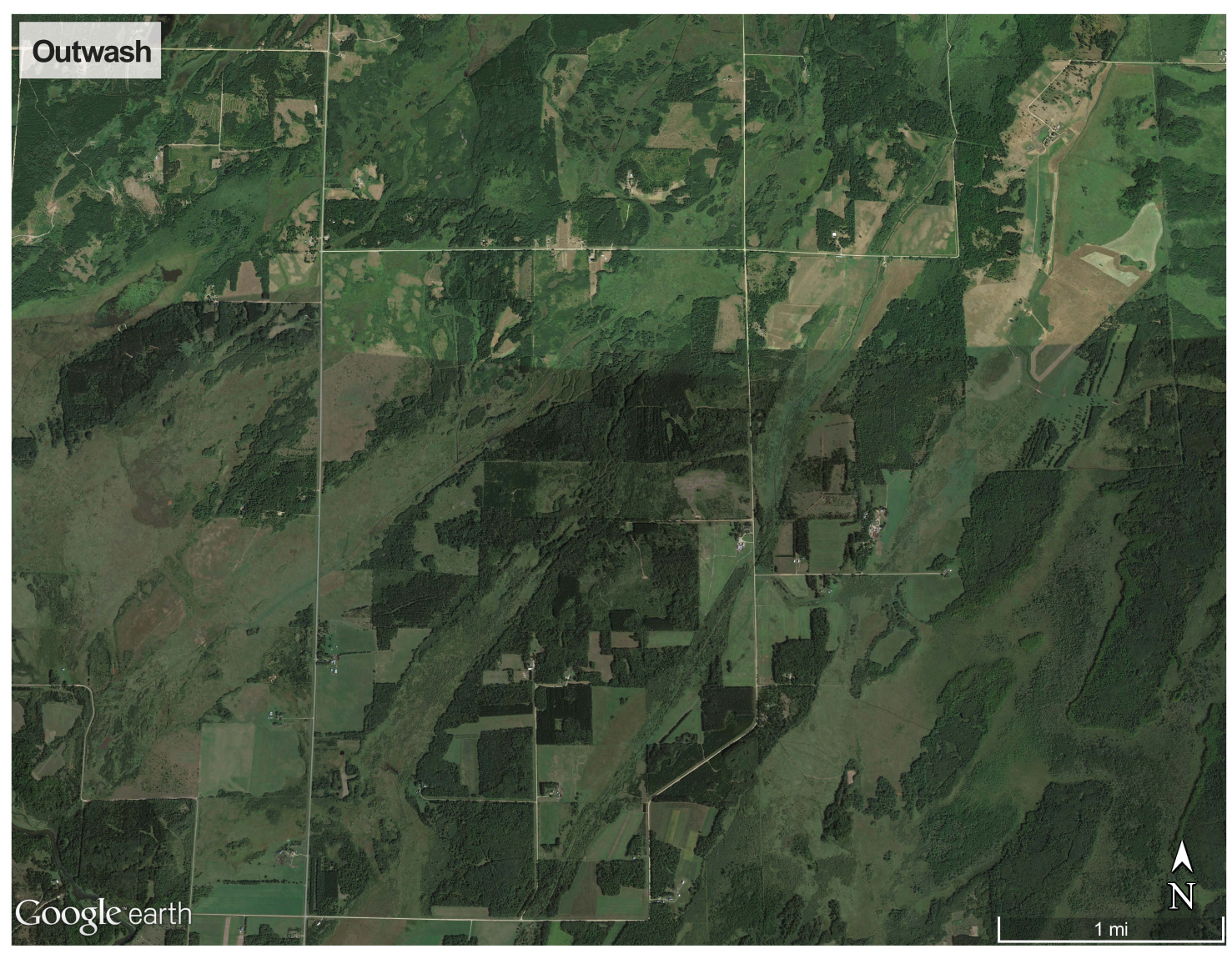

Figure 1.7. Satellite image of outwash within the study site. Image source: Google Earth, earth.google.com/web/.

A peatland landform is formed from decomposed and decayed wetlands vegetation in a low oxygen environment, creating massive organic soil deposits accumulated over thousands of years (Figure 1.8). In Minnesota, the water level is stable and close to the ground surface and includes some remaining dead vegetation that are not fully decomposed. The topography is usually flat, and some concave peatlands interspersed with a string-like pattern of hummocks. 


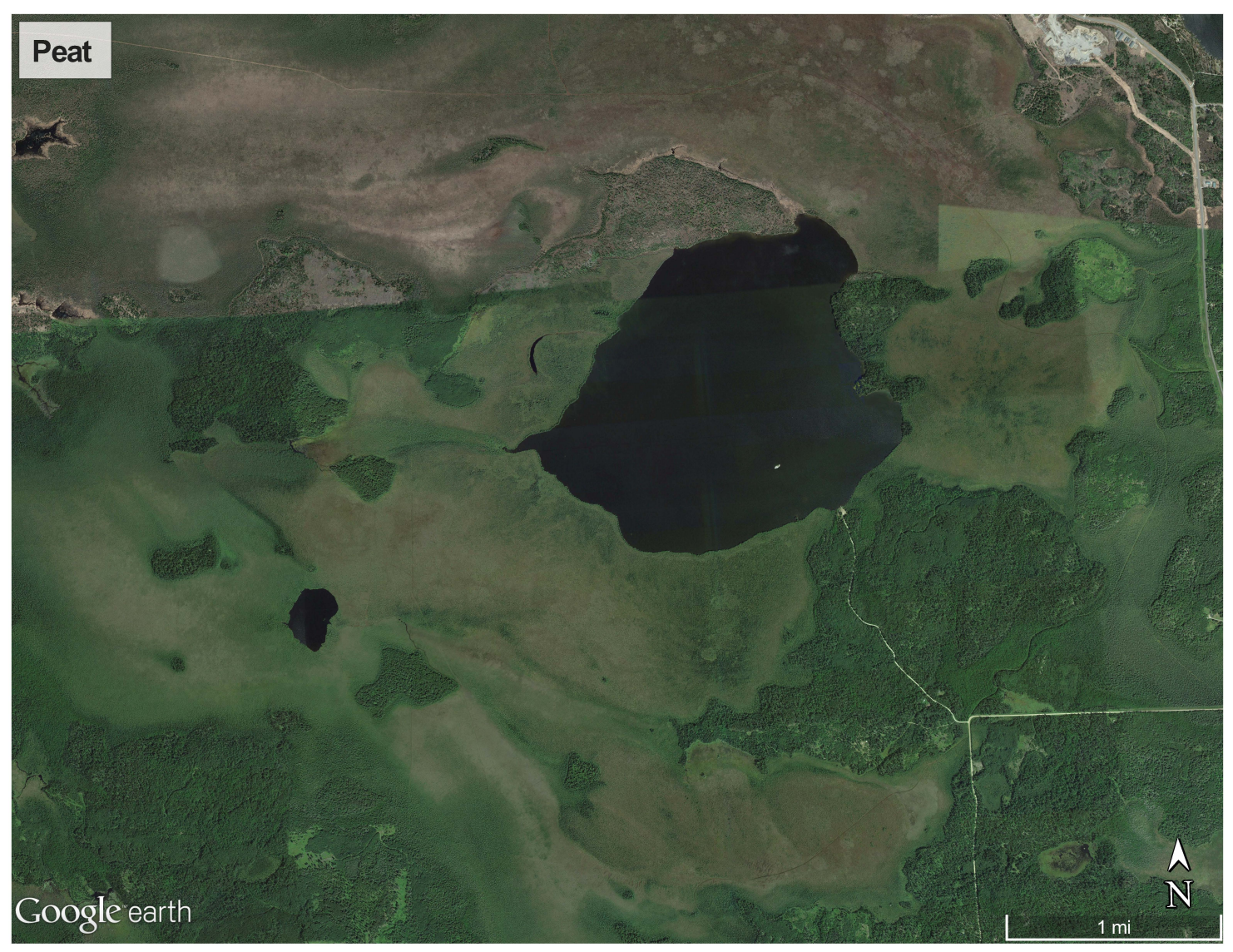

Figure 1.8. Satellite image of peatland within the study site. Image source: Google Earth, earth.google.com/web/.

Till plains are created when debris loaded ice detached from the main glacier, melted in place, and deposited carried sediments (Figure 1.9). It consists of a random mixture of different size fragments of angular rocks in a matrix of fine grained, sand to clay sized fragments that were produced by abrasion within the glacier. The topography varies from rolling to flat depend on the rock types (Nelson, 2015). 


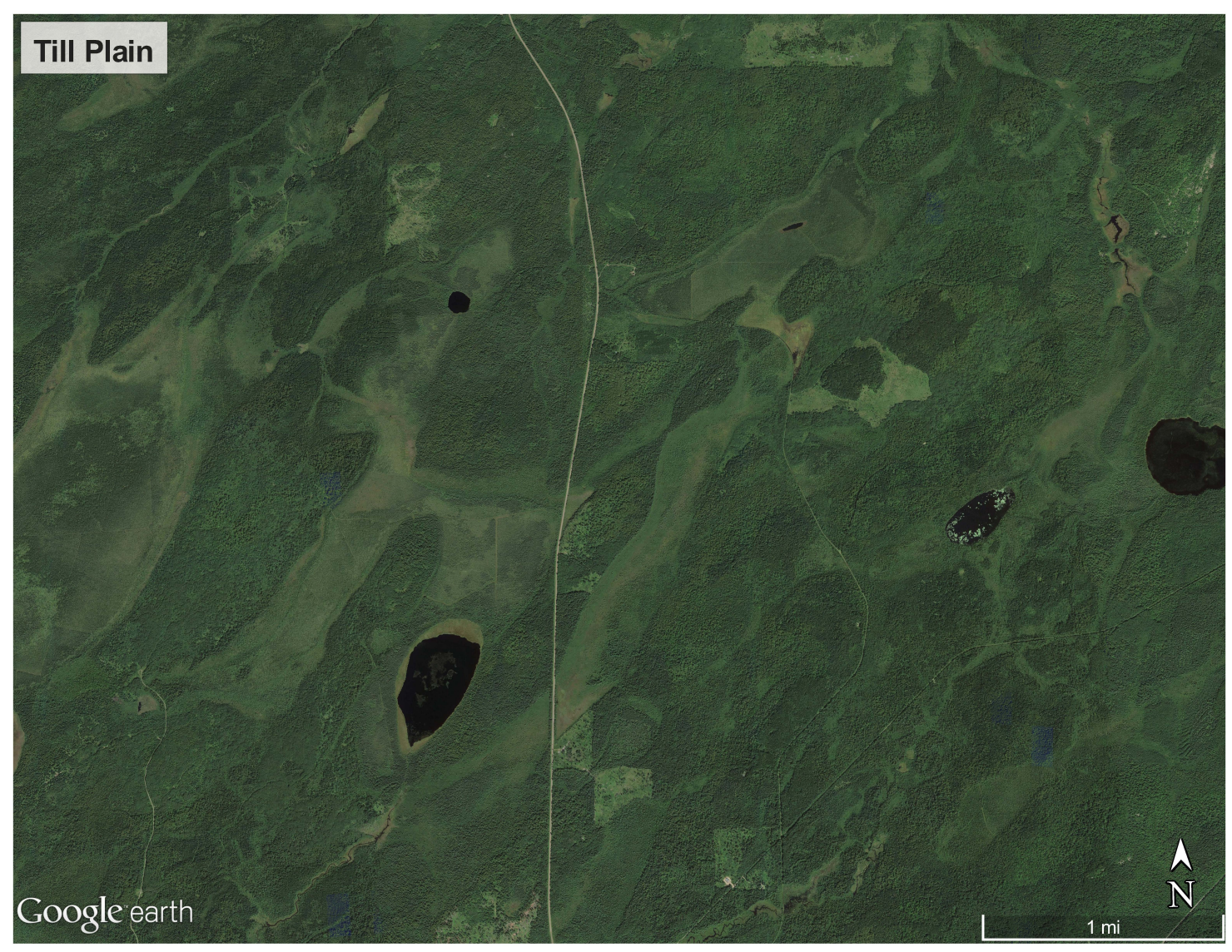

Figure 1.9. Satellite image of till plain within the study site. Image source: Google Earth, earth.google.com/web/.

The RBDM delineates riparian buffer boundaries utilizing watershed boundaries. Using the NHD HUC 12 watershed boundaries facilitated selection of watersheds with a range of stream orders located within single landform as opposed to using more extensive and generalized HUC 8 or 10 watersheds. The HUC 12 watershed areas range between 2,134 ha $(5,273 \mathrm{ac})$ and $16,187 \mathrm{ha}(40,000 \mathrm{ac})$. In order to minimize anthropogenic influences, selected watersheds did not include extensively ditched/drained areas or mining operations. These are two largest anthropogenic influences in the study area.

In addition, the RBDM requires all spatial data to be registered to a planar projected coordinate system. Distances for stream segments are measured using planar X, Y coordinates. The sampling method along the stream network calculates a horizontal interval of $75 \%$ of the pixel's spatial resolution to reduce sampling bias. With 1-meter DEMs, the interval is $0.75 \mathrm{~m}$. When point locations are generated, the actual ground distance between them may be greater than $0.75 \mathrm{~m}$ due to elevation changes and slope. This observation lead to the second research question: if sample points are located along equal intervals of ground distance, would this provide a better delineation of the riparian area than the original planar coordinate sampling method using Euclidean 
distance? A closely related question is: does the spatial resolution of DEM influence riparian buffer delineation when comparing the two different sampling methods?

In summary, the three research questions for this study are:

- How do geomorphic landforms and their associated landscape characteristics influence riparian areas in terms of shape and complexity?

- Do sampling methods of the RBDM (ground distance vs. horizontal (planar) distance) along the water course impact the extent and complexity of the riparian area?

- Does the spatial resolution of DEM influence riparian buffer delineation using the two different sampling methods?

\subsection{References}

Abood, S. A., and Maclean, A. L., 2018. Riparian Buffer Delineation Model for ArcPro. Version 5.1. www.riparian-solutions.

Abood, S. A., Maclean, A. L., and Mason, L. A., 2012. Modeling Riparian Zones Utilizing DEMS and Flood Height Data via GIS. Photogrammetric Engineering and Remote Sensing. 78(3):259-269.

Cowardin, L. M., Carter, V., Golet, F. C., and LaRoe, E. T., 1979. Classification of wetlands and deepwater habitats of the United States. Washington, DC: U.S. Fish and Wildlife Service. FWS/OBS-79/31.

Hanowski, J., Danz, N., and Lind, J., 2007. Breeding Bird Response to Riparian Forest Management: 9 Years Post-Harvest. Forest Ecol. Manage. 241 (2007), pp. 272-277.

Hoffman, P. F., and Bowring, S. A., 1984. Short-lived 1.9 Ga continental margin and its destruction, Wopmay Orogen, north west Canada: Geology, v. 12, p. 68-72.

Ilhardt, B. L., Verry, E. S., and Palik, B. J., 2000. Defining riparian areas. In: Verry, E.S.; Hornbeck, J.W.; Dolloff, C.A., eds. Riparian management in forests of the continental eastern United States. Boca Raton, FL: Lewis Publishers: 23-42.

Integrated Publishing. 2003. Geologic Analysis. URL: http://www.tpub.com.

Macdonald, E., Burgess, C. J., Scrimgeour, G. J., Boutin, S., Reedyk, S., and Kotak, B., 2003. Should Riparian Buffers be Part of Forest Management Based on Emulation of Natural Disturbance? Forest Ecol. Manage., 187 (2003), pp. 185-196. 
Mason, L. 2007. GIS Modeling of Riparian Zones Utilizing Digital Elevation Models and Flood Height Data: An Intelligent Approach. M.S. Thesis, Michigan Technological University, Houghton, Michigan, 75p.

Minnesota Department of Natural Resources, 2016. Ecological Classification System: Laurentian Mixed Forest Province. URL: https://www.dnr.state.mn.us/ecs/212/index.html

Minnesota Geospatial Information Office. 2012. LiDAR Elevation Data for Minnesota. URL: http://www.mngeo.state.mn.us/chouse/elevation/lidar.html

Mitsch W. J. and Gosselink J. G., 1993. Wetlands (Second Edition). New York: Van Nostrand Reinhold. 722 p.

Nelson, S. 2015. Physical Geology: Glaciers and Glaciation. Tulane University, Earth \& Environmental Science 1110.

Palik, B., Zasada, J., and Hedman, C., 2000. Ecological Considerations for Riparian Silviculture. In Verry, E. S., Hornbeck, J. W., and Dolloff, C. A. eds. Riparian Management in Forests of the Continental Eastern United States. Lewis Publishers, New York. pp. 233-254.

Peacefull, Leonard, ed. 1996. A Geography of Ohio. Kent, Ohio: Kent State University Press.

Riparian Science Technical Committee MN, 2007. Analysis of the Current Science behind Riparian Issues. Minnesota Forest Resources Council.

Skally, C., and Sagor, E., 2001. Comparing Riparian Management Zones to Riparian Areas in Minnesota: a Pilot Study. Minnesota Forest Resources Council, Research Report 1001.

United States Department of Agriculture. 2017. Gridded Soil Survey Geographic Database. URL:

https://www.nrcs.usda.gov/wps/portal/nres/detail/tx/home/?cid=nrcs142p2_053628

U.S. Fish \& Wildlife Service. 2017. National Wetlands Inventory. URL:

https://www.fws.gov/wetlands/

United States Geological Survey. 2017. USGS National Hydrography Dataset. URL: http:// nhd.usgs.gov/index.html

United States Geological Survey (USGS). 2017. USGS Water Data for USA. URL: https://waterdata.usgs.gov/nwis? 
Verry, E.S., Dolloff, C. A., and Manning, M. E., 2004. Riparian Ecotone: a Functional Definition and Delineation for Resource Assessment. Water, Air, and Soil Pollution:

Focus, 4:67-94. 


\section{The Influence of Geomorphic Landform on Riparian Management Zones}

\subsection{Introduction}

A riparian management zone is an area of interaction between aquatic and terrestrial ecosystems along streams, lakes, wetlands, and other water bodies. It performs critical ecological functions that link aquatic and terrestrial ecosystems (Riparian Science Technical Committee MN, 2007). Delineating accurate riparian management zones (RMZs), often utilized in Best Management Practices (BMPs) for wetland and stream protection, is important. Riparian zones effectively moderate microclimate at a local scale, and multiple conservation goals are achieved, such as nutrient trapping, stream bank stabilization, flood attenuation and wildlife movement corridors. The zones also provide habitat for a wide variety of flora and fauna. For this study, Ilhardt's et al. (2000) definition of a riparian buffer is utilized. They define a riparian zone as a threedimensional space of interactions which include terrestrial and aquatic ecosystems extending downward into the groundwater table, upward to include the canopy, outward across the floodplain, up near-slopes, and along the water course at a variable width. A key phrase to note here is 'variable width'.

Fixed width RMZs or buffers, which are simple to delineate, implement and monitor, were regarded as the standard of practice for many years to protect waterbodies from adverse impacts of development, mining, timber harvesting and agricultural runoff. Before the commercialization and widespread use of Global Positioning Systems (GPS), a fixed width buffer was the easiest to map and monitor on the ground. However, Palik et al. (2000) showed fixed width RMZs were inadequate and inaccurate as these buffers cannot replicate natural or true riparian zone boundaries since they have no functional relationship to the naturally varying watercourse and its associated land cover. In addition, research conducted by Skally and Sagor (2001) in northern Minnesota concluded riparian buffer boundaries were, on average, 2.5 times farther from the water course than the BMP fixed width buffer. Research by Macdonald et al. (2003) and Hanowski et al. (2007) supports these conclusions.

The Riparian Buffer Delineation Model (RBDM), unlike other buffer delineation models, considers two important characteristics of any RMZ: the watercourse and and its associated floodplain. Research by Ilhardt et al. (2000), determined the 50-year floodplain was the optimal hydrologic descriptor of a RMZ. By hydrologically defining a RMZ as occurring at the 50-year flood height and incorporating digital elevation data (DEM) with the spatial modeling capabilities of ArcPro GIS software, the RBDM was developed and implemented (Mason, 2007; Abood and Maclean, 2012; Abood and Maclean, 2018). The RBDM is used extensively by various government agencies, NGOs, academic programs, private companies, and individuals. It has undergone rigorous validation for accurate boundary delineation (Abood, 2018). Details on RBDM 
functionality are found in Abood (2011), Abood and Maclean (2012) and at Riparian.Solutions.

Landforms are created by the physical or chemical decomposition of rock through glaciation, weathering, erosion and other geological processes. A wide diversity of landforms exists across the earth's landscape, and their influence on land use and land cover is well documented (Lillesand et al., 2015). However, the impact of landform depositional drainage patterns and associated erosional drainage patterns on the areal extent and shape complexity of RMZs is not well understood. Utilizing a validated RMZ delineation model, such as the RBDM, facilitates analysis of the impact landform characteristics have on riparian area form and function. Ideally, this leads to an improved understanding of ecological processes within these zones. Hence the key question for this study is: how do environmental factors, such as landform and its associated soils, hydrologic conditions, and topography influence riparian area extent and shape complexity?

\subsection{Study Site Selection Criteria}

The complex and multiple glaciations which occupied the Upper Midwest during the Pleistocene Epoch are unique. During the Wisconsin glacial stage most of the area was covered by a thick ice sheet resulting in a massive deposition of glacial drift. The drift and its associated glacial ice created a wide variety of landforms (Jerome, 2006) throughout the area, making it an excellent location for study site selection.

To minimize climatic influences, Ecological Provinces are the first criteria in study site selection. These landscape units are delineated using major climatic zones, similar soil orders, native vegetation and biomes (Albert, 1995). The basic assumption is that climate governs energy and moisture gradients, thereby acting as the primary control over more localized ecosystems (Cleland et al., 1997). External environmental factors throughout the whole area are similar. For example, significant differences in temperature or precipitation moving south to north or west to east are minimized. The northern one third of Wisconsin, Michigan's Upper Peninsula plus the northern half of the Michigan's Lower Peninsula, and the northeastern two thirds of Minnesota are in Ecological Province 212 (Laurentian Mixed Forest (LMF)) (Figure 2.1). This area is dominated by native forests, wetlands, and open meadows and has been minimally impacted by resource development, urbanization and other anthropogenic activities. These activities often introduce large areas of impervious surfaces, alter drainage patterns and destroy riparian areas and wetlands.

In northeastern Minnesota, the LMF Province is characterized by broad areas of conifer forest, mixed northern hardwood and conifer forests, and conifer bogs and swamps. The landscape varies from rugged lake-dotted terrain with thin glacial deposits over bedrock, 


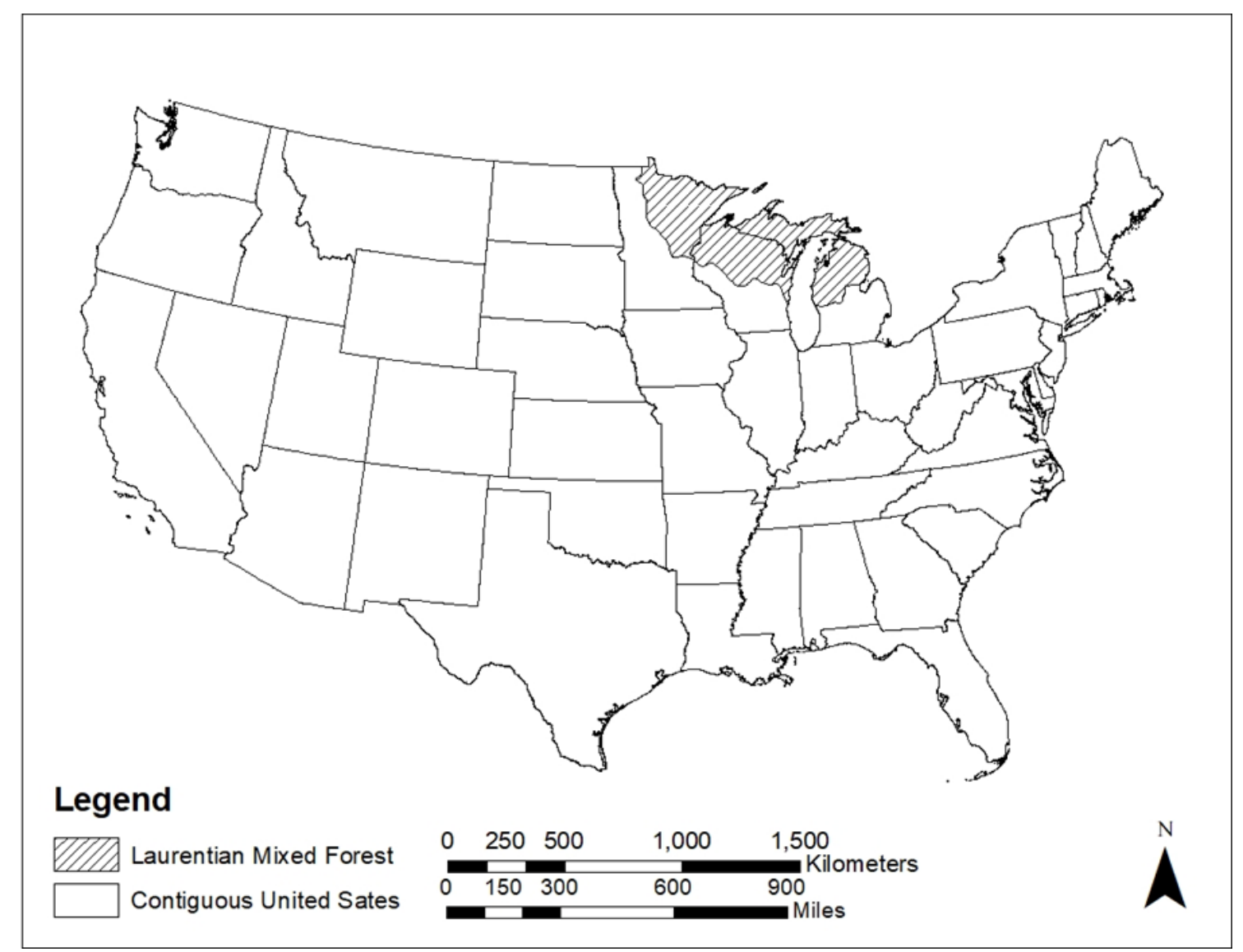

Figure 2.1. Laurentian Mixed Forest extent in the Upper Midwest used in study site selection. Data source: United States Department of Agriculture Forest Service and US Census Bureau. Coordinate system: USA Contiguous Albers Equal Area Conic.

hummocky or undulating plains with deep glacial drift, and large, flat, poorly drained peatlands. Precipitation ranges from $53 \mathrm{~cm}$ (21 in) annually along the western border of the Province to $81 \mathrm{~cm}$ (32 in) in northeastern Minnesota. Annual average temperatures are $1^{\circ} \mathrm{C}\left(34^{\circ} \mathrm{F}\right)$ along the northern part of the Province in Minnesota, rising to $4^{\circ} \mathrm{C}\left(40^{\circ} \mathrm{F}\right)$ at its southern boundary (Minnesota Department of Natural Resources, 2016). With these similarities, climatic factors that significantly contribute to the extent and complexity of the riparian areas are minimized.

Additionally, the study area must have standardized, consistent, high quality spatial data which are required by the RBDM, including digital elevation modes (DEMs), hydrography data including wetlands, and detailed soils information. Land use/cover data is also desirable, but not required. Finer spatial resolution data is required to map detailed changes across different landforms. Data with known positional errors is necessary since these carry through to the location of riparian boundaries (Abood, 2019). There also needs to be an adequate number and good distribution of stream gauges across the area since 50-year flood height is a required input into the RBDM. Previous studies have 
shown this to be the most difficult data requirement to achieve (Abood and Maclean, 2018), and gauges outside of a watershed may need to be utilized.

The 1:100,000 Geomorphology of Minnesota map (Thomas, 2014), describes a wide variety of conditions related to surficial geology within a hierarchical classification scheme. It contains multiple dominant surficial landforms, and some lesser landforms (Figure 2.2). While this dataset is at a coarser scale than the other inputs, it does provide the required landform boundaries. When overlaid on finer scale data, the boundaries are refined and updated as needed.

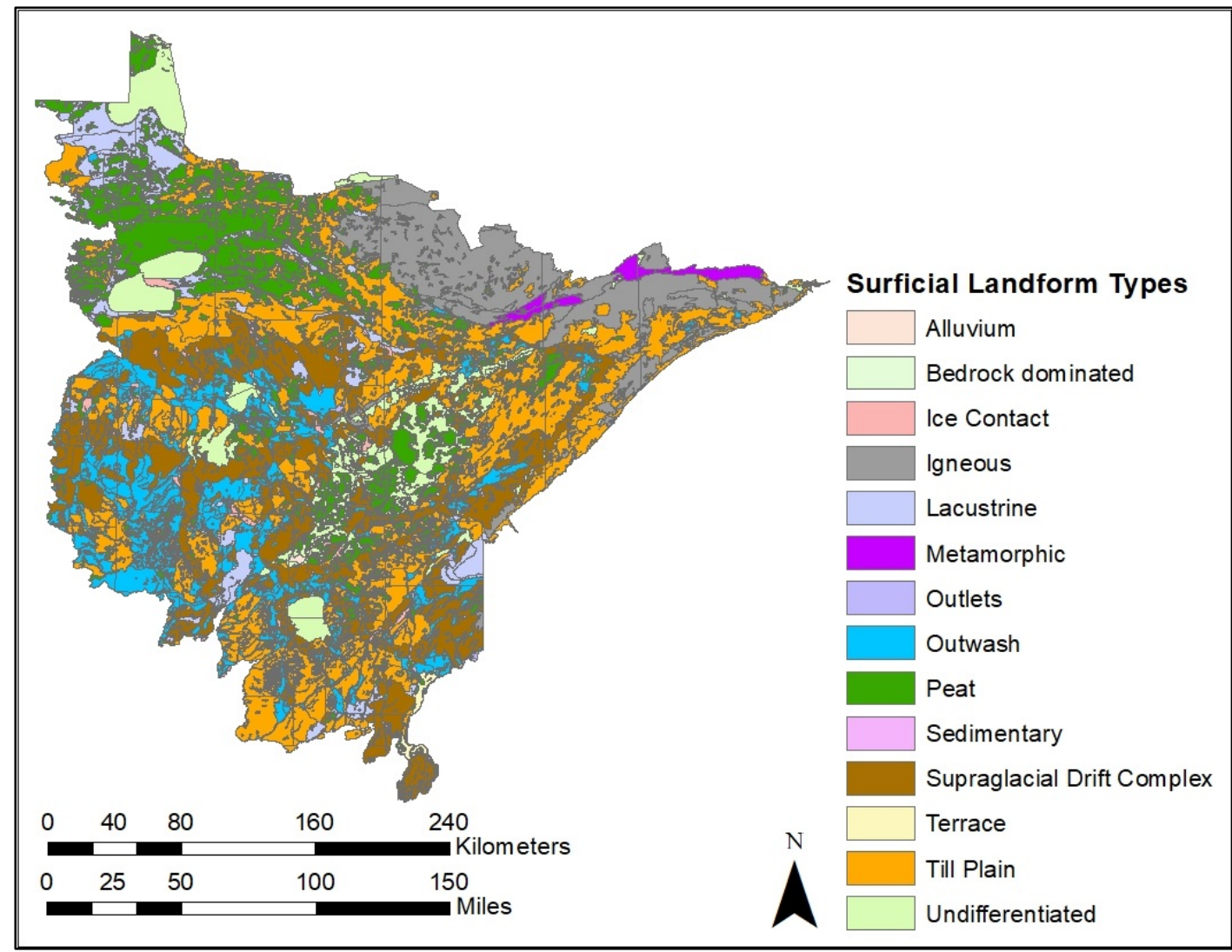

Figure 2.2. Surficial landform types for northeast Minnesota within the LMF Province. Data source: Minnesota Department of Natural Resources and USGS National Hydrography Dataset. Coordinate system: NAD 1983 UTM Zone 15N.

Six landforms, representing the dominant formation characteristics for the province, are utilized for the study:

- Metamorphic: created from the transformation of underlying rocks subjected to high temperatures and pressures;

- Peatland: formed from decomposed and decayed wetland vegetation creating massive organic soil deposits accumulated over thousands of years (Thomas, 2014). 
- Outwash: formed from glacier sediments deposited by meltwater at the terminus of a glacier;

- Supraglacial Drift Complex: composed of coarsely graded and complex glacial sediments;

- Igneous: formed from cooling and consequent solidification of magma; and

- Till Plain: created when debris loaded ice detached from the main glacier, melted in place, and deposited carried sediments.

Further details on these landforms can be found in Ding (2020).

The RBDM delineates RMZs utilizing watershed boundaries, and standardized watershed data are needed for consistent delineation across large areas. Using the NHD (National Hydrography Dataset) HUC 12 watershed boundaries facilitated selection of watersheds with a variety of stream orders located within single landform when compared to using more spatially extensive HUC 8 or 10 watersheds. The HUC 12 watersheds range between 2,134 ha $(5,273 \mathrm{ac})$ and 16,187 ha $(40,000 \mathrm{ac})$. In order to minimize anthropogenic influences, selected watersheds do not include extensively ditched/drained areas or mining operations. Forty-two watersheds (Figure 2.3) are utilized. Details on the selected watersheds are found in Appendix A.

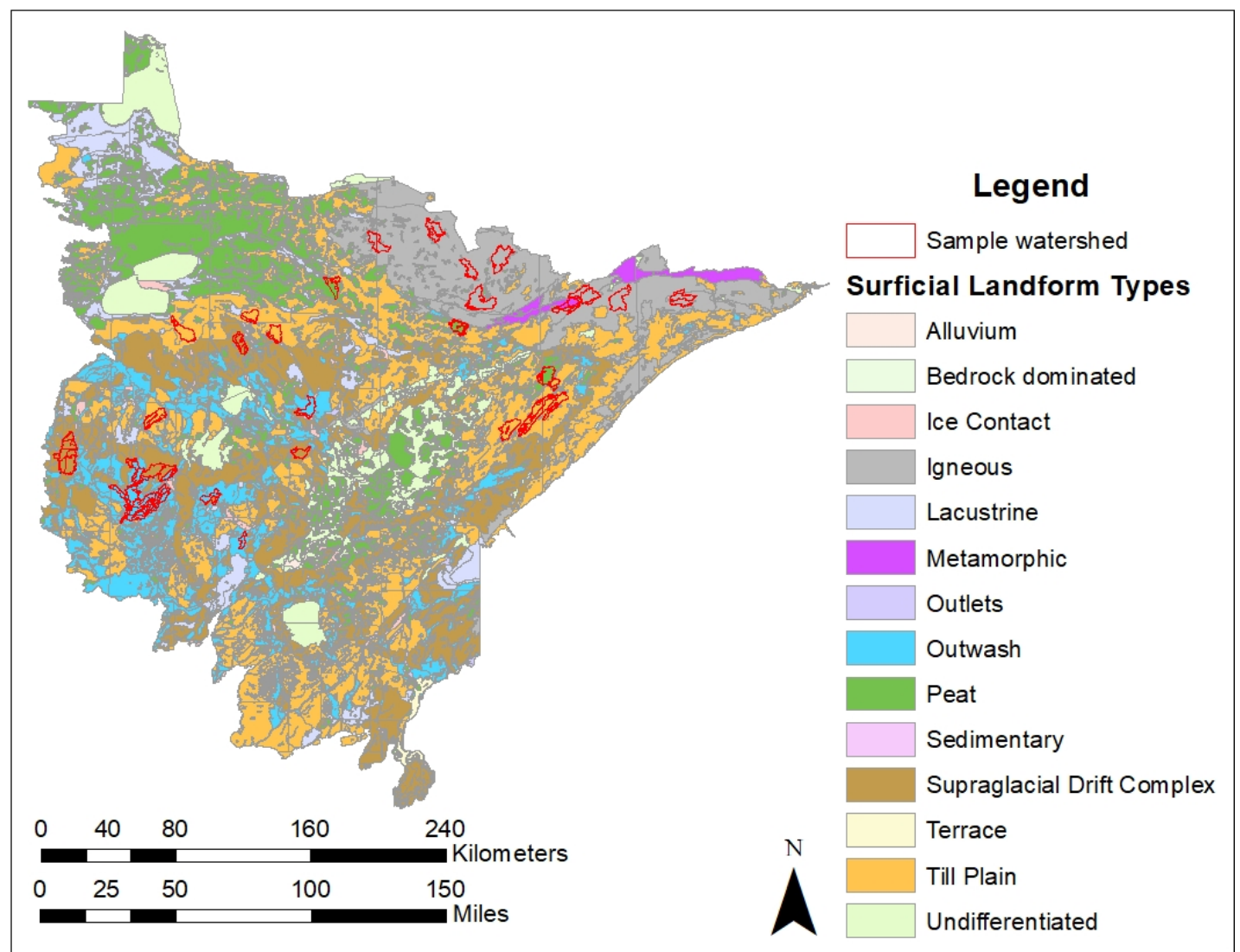

Figure 2.3. Watershed locations selected for the study overlaid on the landform types. Data source: Minnesota Department of Natural Resources and USGS National Hydrography Dataset. Coordinate system: NAD 1983 UTM Zone 15N. 


\subsection{Methodology}

Within the study area 23 USGS stream gauges with a minimum 10 years of field measurements and annual statistics were selected for the 50-year flood height calculations (Figure 2.4). These calculations are performed using the procedure developed by Mason (2007) and require average annual and periodic flow rate, velocity, recurrence intervals, cross sectional, and channel width data.

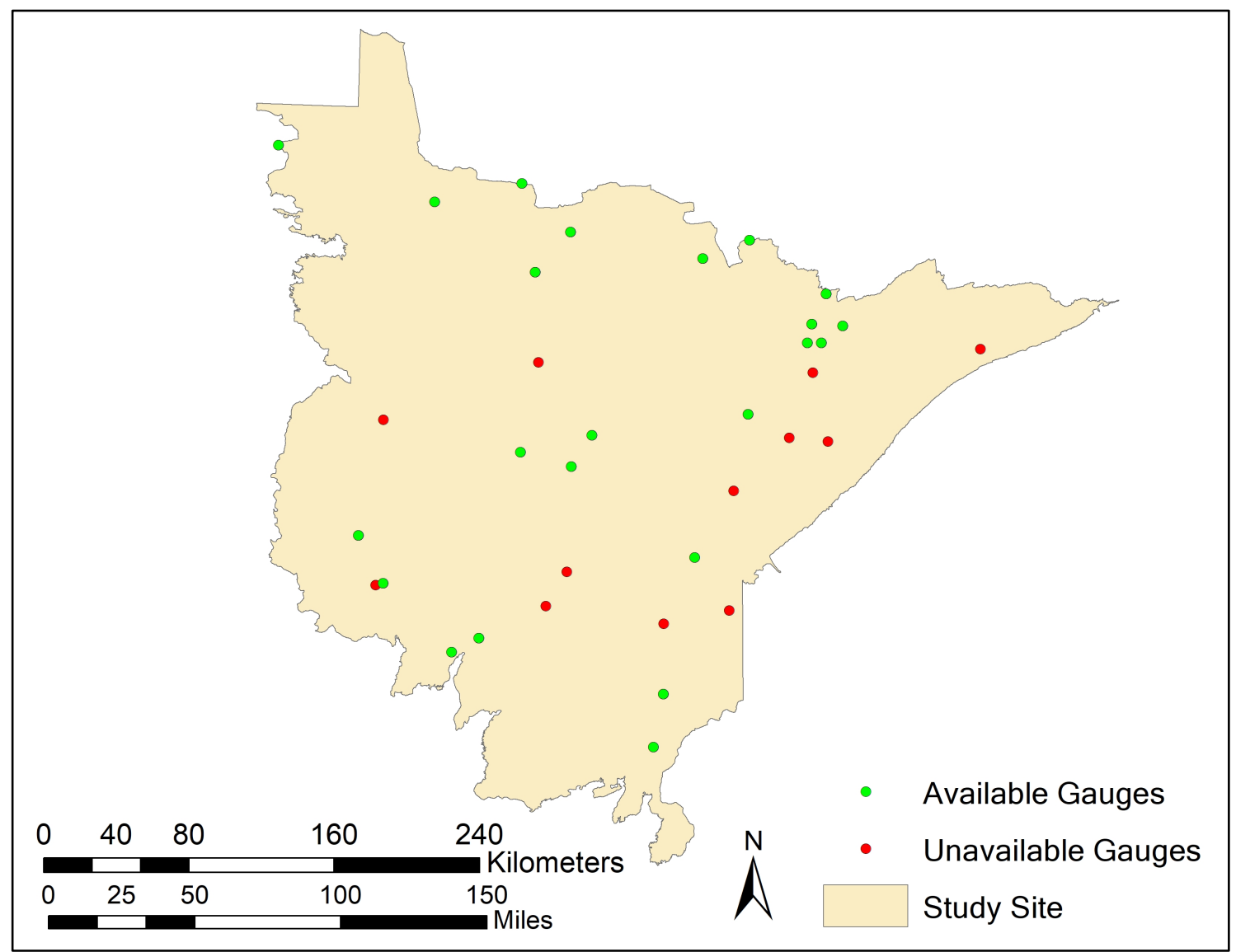

Figure 2.4. Locations of the stream gauges in the study site. Data source: Minnesota Department of Natural Resources and USGS Water Data. Coordinate system: NAD 1983 UTM Zone $15 \mathrm{~N}$.

Overlaying the stream gauge location with landform type and NHD stream order information ascertains the landform and stream order for each gauge. Then for each landform type/stream order, a 50-year flood height regression equation is calculated. For example, within the outwash landform, minimum and maximum flood heights are plotted for each represented stream order (Figure 2.5). Using the regression equation with the highest $\mathrm{R}^{2}$ value, a 50-year flood height is ascertained for each stream order. It is critical to have adequate number stream gauges within the study area; otherwise the regression equation is not be able to represent the flood heights of different stream orders. The flood 
heights are added as a new attribute field to the stream feature class based on stream order (Table 2.1).

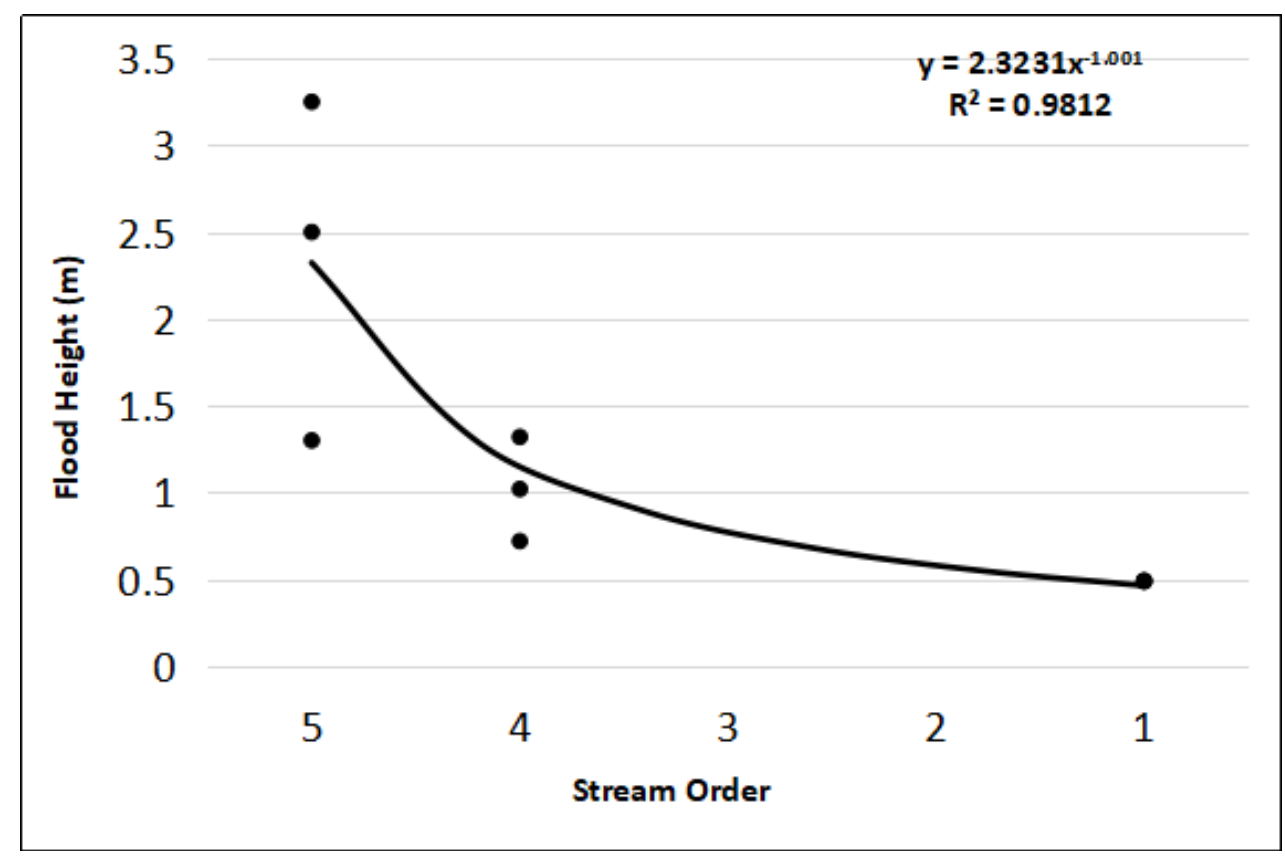

Figure 2.5. Flood height regression plot for the outwash landform.

Table 2.1. Flood heights for various stream orders within the outwash landform.

\begin{tabular}{cc}
\hline Stream Order & Flood Height (m) \\
\hline 5 & 2.32 \\
\hline 4 & 1.16 \\
\hline 3 & 0.77 \\
\hline 2 & 0.58 \\
\hline 1 & 0.46 \\
\hline
\end{tabular}

An individual file geodatabase (GDB) is created for each watershed. Lidar derived 1meter DEMs are imported into the GDB as raster datasets, and the NHD data are imported as a feature class. However, the scale of the NHD data $(1: 24,000)$ is not fine enough for accurately mapping the stream channel when overlaid on the 1-meter DEM. There are instances of flow lines located on the sides of hills and even going over hills. This results in highly inaccurate output from the RBDM. Arc Hydro is used to digitize refined, more accurate stream channels based on the Multi-Directional Oblique Weighted (MDOW) Hillshade generated from the 1-meter DEMs. (Figure 2.6). The workflow process is presented in Figure 2.7. It is important to note where bridges cross streams, the software is not able detect flow direction since it is interrupted by the higher elevation of the bridge. Therefore, the stream channel is incorrectly mapped. Those stream segments are manually corrected. 


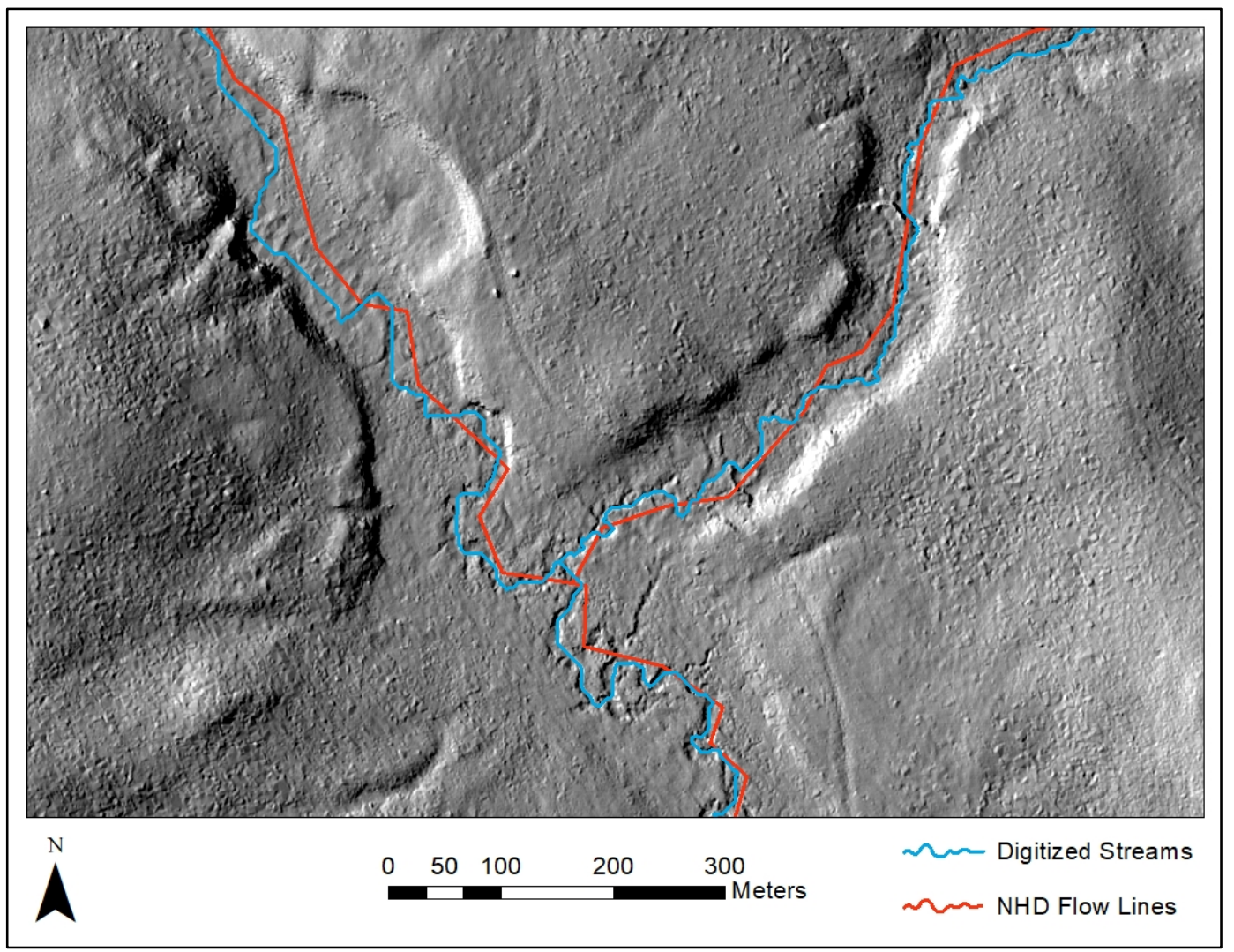

Figure 2.6. Illustration between locations of digitized stream channels and original NHD flow lines.

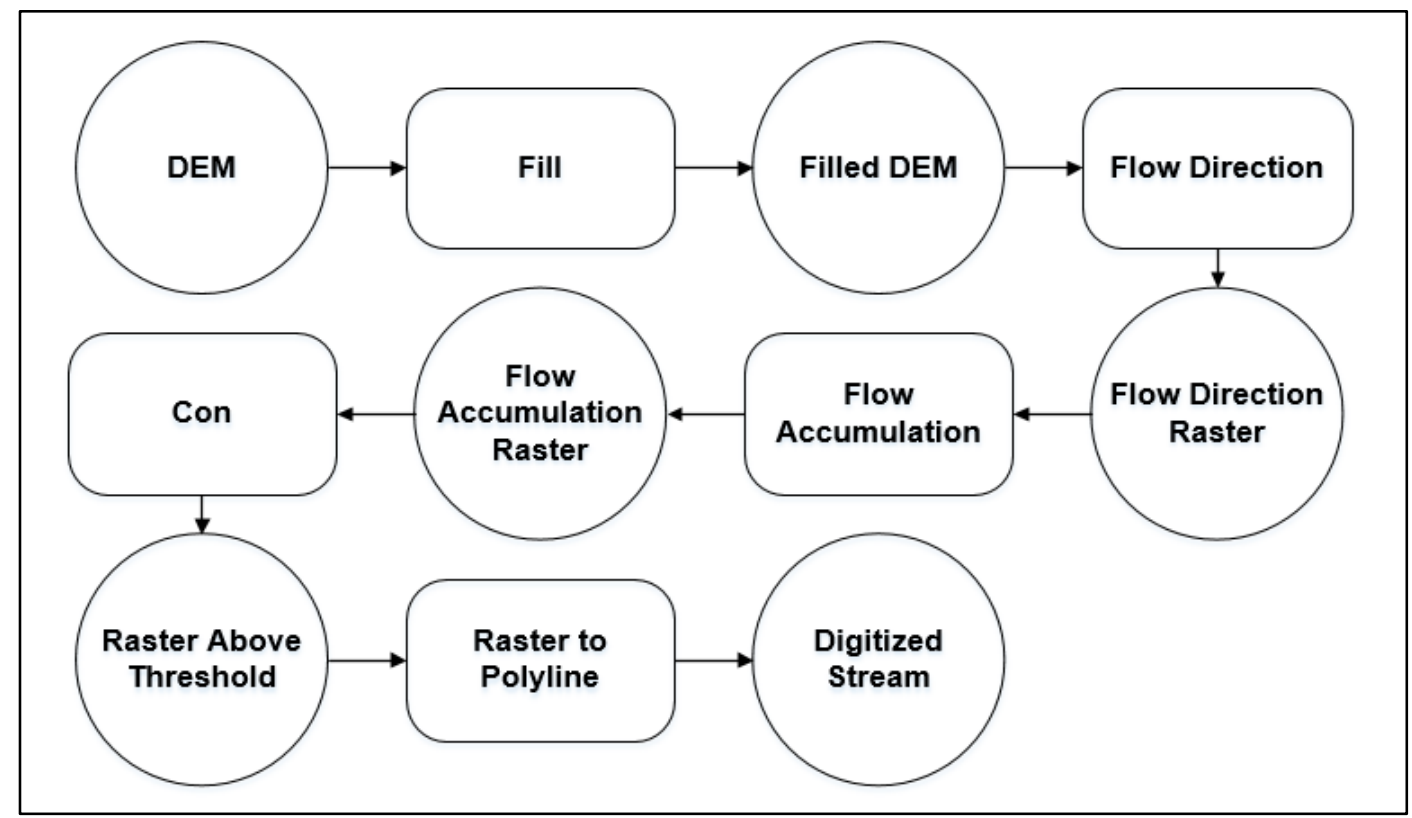

Figure 2.7. Workflow for digitizing improved stream channel locations from 1-meter DEMs using Arc Hydro tools. 
Utilizing the digitized stream channels, basic variable width riparian buffer zones are delineated with the RBDM. The basic riparian area delineations are based on 50-year flood heights, elevation data, NHD stream orders and stream channel locations. The correct sampling distance from the stream is important to ensure the 50-year floodplain is mapped in its entirety. The floodplain extent will be underestimated by a sampling distance that is too short. Whereas a sampling distance which is too long utilizes extra computer RAM and increases processing time. Based on previous studies, a sampling distance of 250 meters used.

The basic riparian buffer calculated by the RBDM is utilizing changes in elevation and stream order within the watershed to determine the spatial extent of the buffer. However, this boundary is often not the true extent of the RMZ, particularly in areas that have undergone extensive glaciation like the Upper Midwest. Hence, wetlands and areas of poorly drained soils contiguous to the basic riparian area must be "added in" for an inclusive riparian area (Abood et al., 2012). This inclusive RMZ provides managers with a more accurate picture of what is on the ground which in turn leads to a better understanding of RMZ function.

The NWI is the only spatially comprehensive wetland inventory for Minnesota, and the original maps were created between 1979 and 1984. The DNR, with funding from the Environmental and Natural Resources Trust Fund, began a statewide update of the NWI in 2008. The wetland inventory has been remapped using GIS technology, including lidar and high-resolution aerial imagery, making it the most comprehensive, current, and accurate wetland inventory in the country. These updated maps are used to map the inclusive riparian buffers for this study.

Wet soils are selected using Palik's et al. (2000) criteria and the gSSURGO soils data. gSSURGO has improvements from the vector based SSURGO soils data (NRCS-USDA, 2015), with finer spatial resolution $(10 \mathrm{~m})$ and better edge matching. There are multiple criteria for a soil to be classified as wet, including hydrologic groups $\mathrm{C}$ or $\mathrm{D}$ (slow infiltration, impeding or impervious layers, fine texture), or combinations of $\mathrm{C}$ or $\mathrm{D}$ and other hydrologic groups $(\mathrm{A} / \mathrm{D}, \mathrm{B} / \mathrm{D}, \mathrm{C} / \mathrm{D})$; and the drainage class of poorly drained $(\mathrm{P})$, very poorly drained (VP) or a combination of poorly drained/somewhat poorly drained (P/SP), or poorly drained/very poorly drained (P/VP). Particularly, useful for this study is a new attribute, Potential Wetland Soil Landscapes (PWSL, Version 1), which provides the percentage of a soil unit meeting the criteria for a potential wetland soil landscape. The hydric rating (soil component attribute "hydricrating") has long been used as an indicator of potential wet soils (NRCS-USDA, 2015). Soil components with hydricrating $=$ "YES" are considered a PWSL. However, if the hydricrating = "UNRANKED", the soil map unit is classified as wet if the PWSL $\geq 80$. Soil polygons meeting these criteria are extracted using ArcGIS Pro's "Select by Location" function and added to the "basic" variable width riparian buffers to create the inclusive riparian areas along with the updated NWI data. 


\subsection{Analysis and Results}

\subsubsection{Extent Parameters}

According to the riparian area definition used by the RBDM, a watershed's stream network and its associated flood plain strongly influence the extent of riparian areas. Larger watersheds with more complex, longer length stream channels potentially have more extensive riparian areas. This includes larger basic riparian areas around the watercourse, and potentially, with more wetlands and/or wet soils contiguous to the basic riparian area, more complex inclusive riparian areas. In order to determine the strength of the relationship, watershed area vs. riparian area (basic and inclusive), and total stream length vs. riparian area (basic and inclusive) are evaluated via linear regression techniques (Figure 2.8 (A and B), Figure 2.9 (A and B), and Table 2).

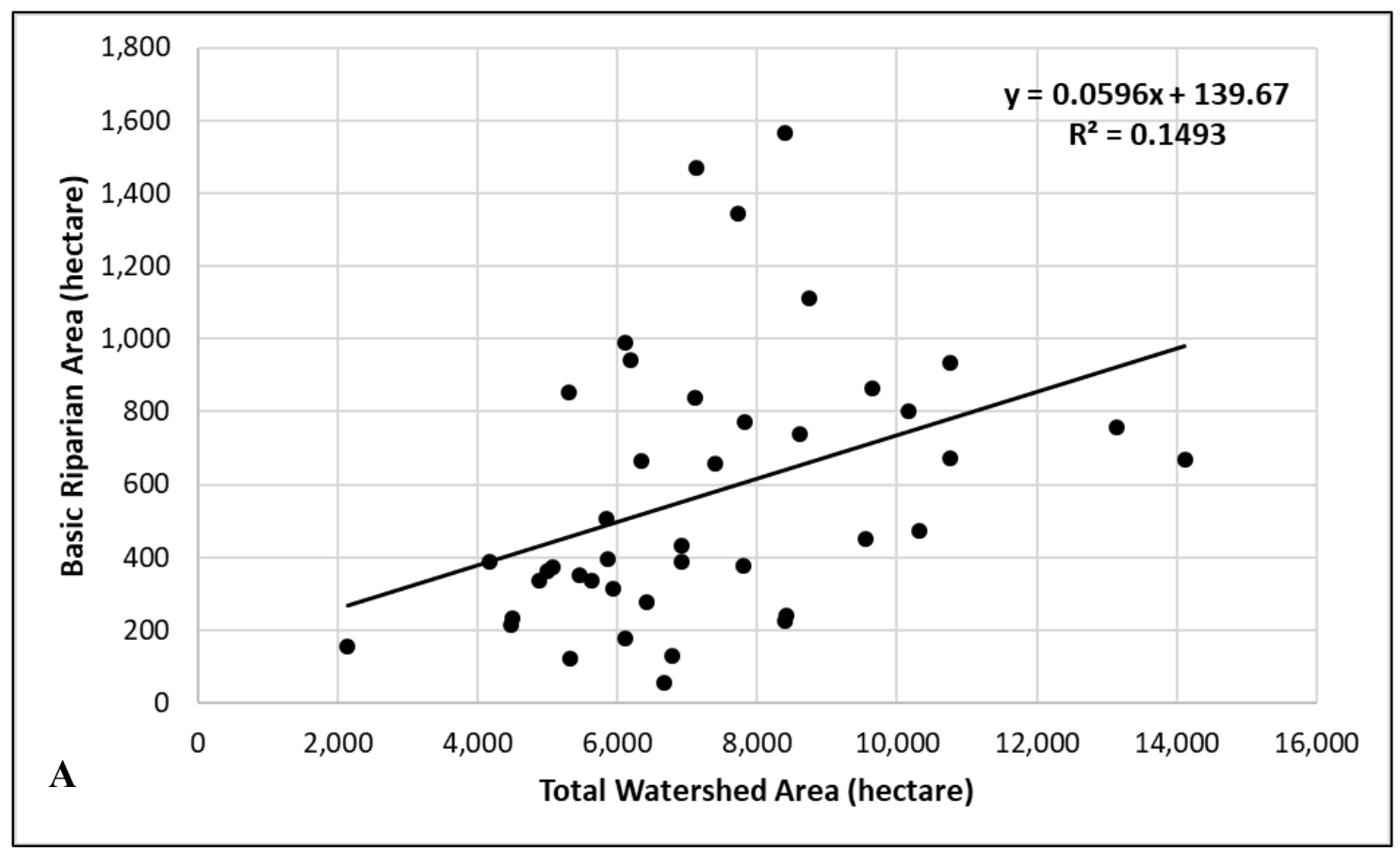




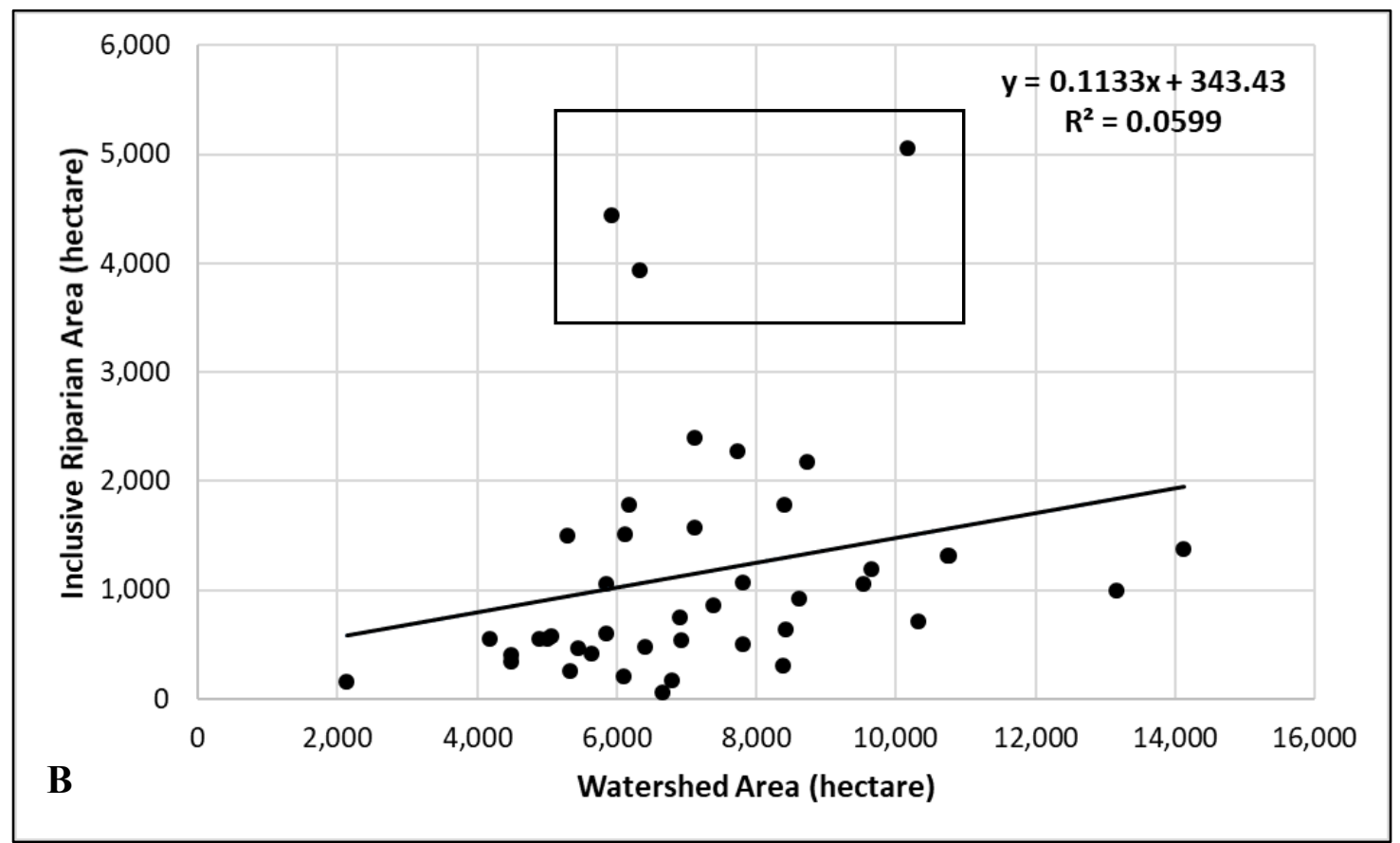

Figure 2.8. Basic riparian area vs. watershed area (A) and inclusive riparian area vs. watershed area (B) regardless of landform. Points within the box indicate potential outliers.

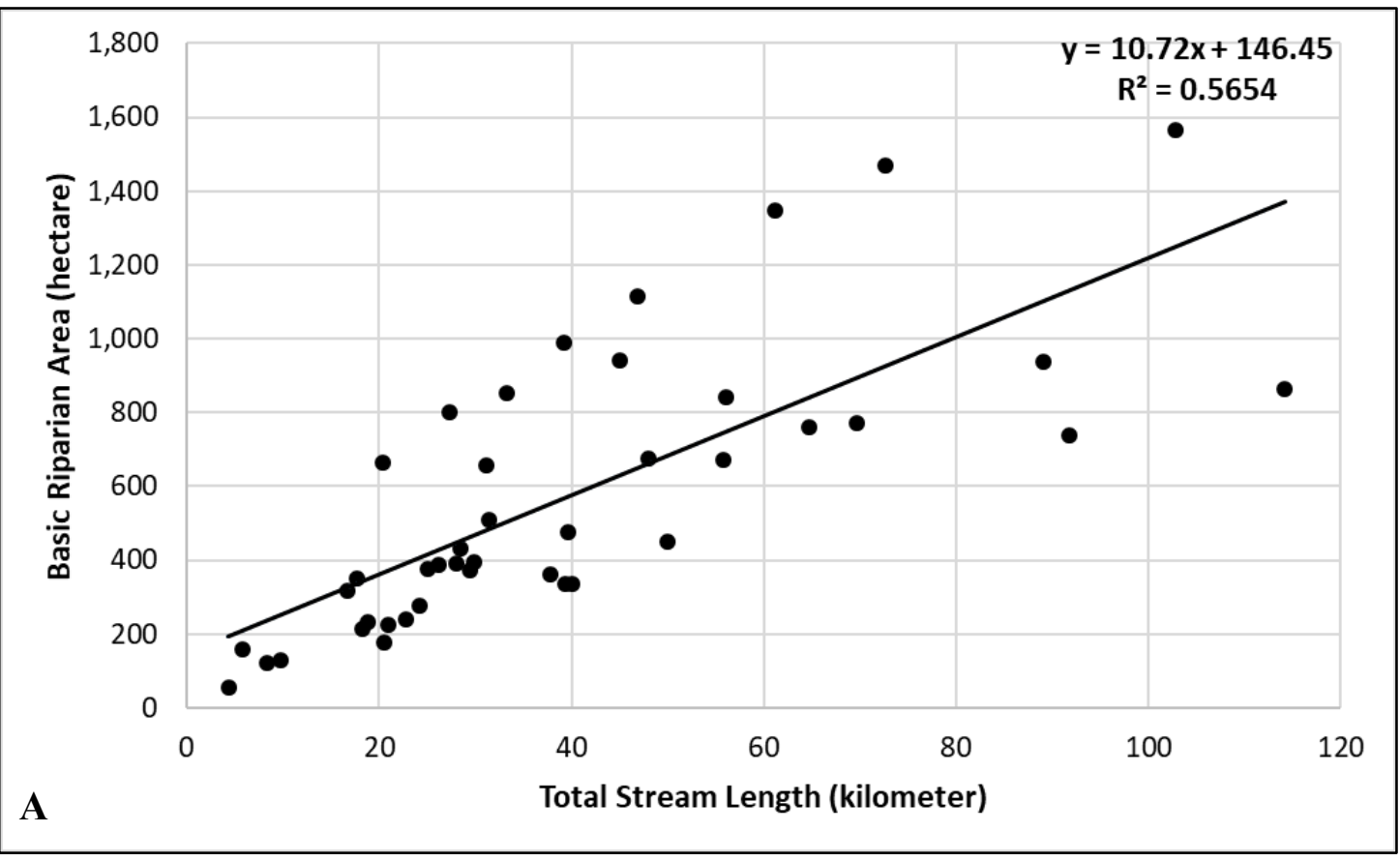




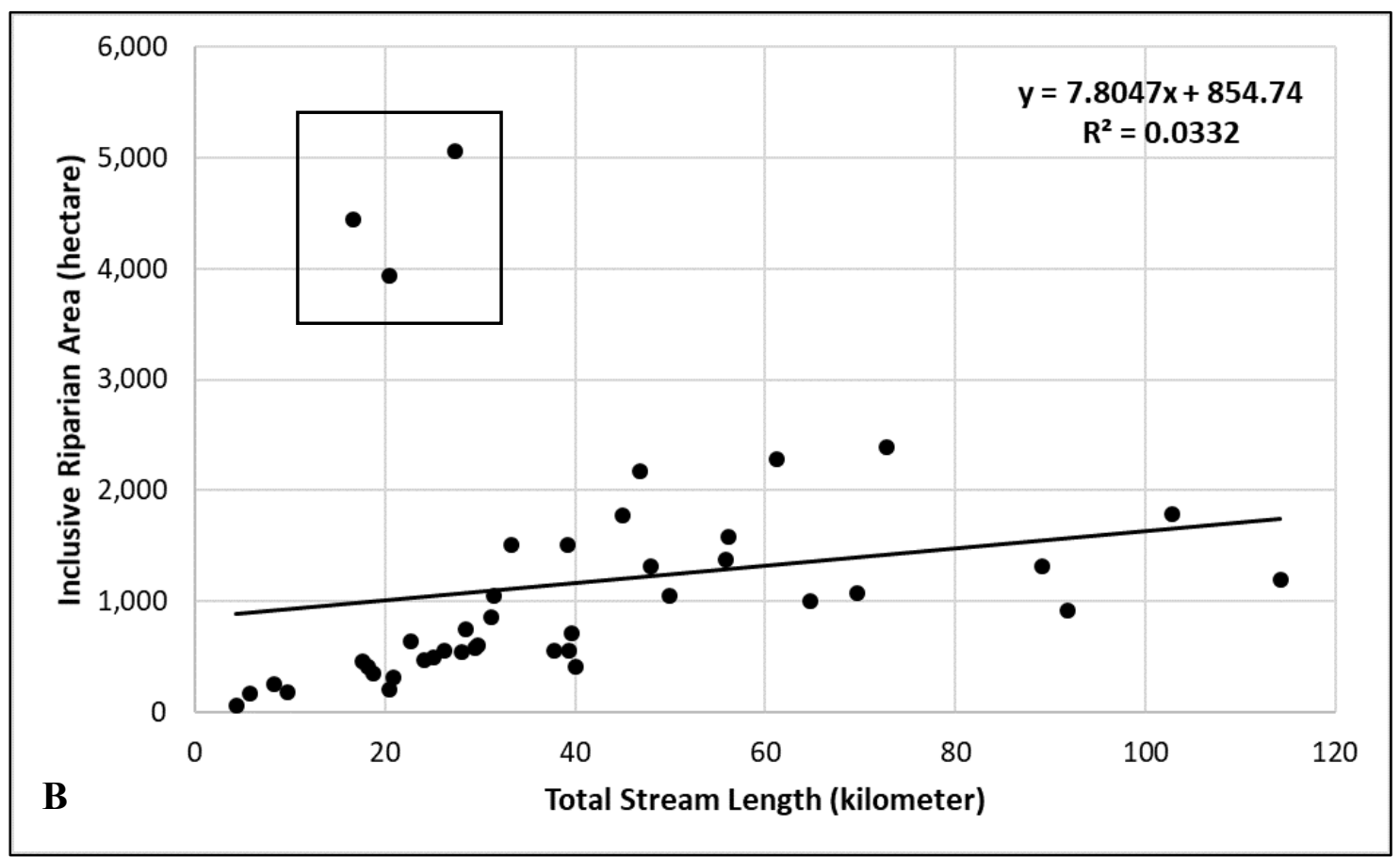

Figure 2.9. Basic riparian area vs. total stream length (A) and inclusive riparian area vs. total stream length (B) regardless of landform. Points within the box indicate potential outliers.

Table 2.2. $\mathrm{R}^{2}$ and RSE between watershed area and riparian area (basic and inclusive), and the relationship between total stream length and riparian area (basic and inclusive) regardless of landform.

\begin{tabular}{cccc}
\hline Parameter & $\begin{array}{c}\text { Riparian Area } \\
\text { Type }\end{array}$ & $\begin{array}{c}\text { Watershed } \\
\text { Area vs. } \\
\text { Riparian } \\
\text { Area }\end{array}$ & $\begin{array}{c}\text { Total Stream } \\
\text { Length vs. } \\
\text { Riparian } \\
\text { Area }\end{array}$ \\
\hline \multirow{2}{*}{$\mathrm{R}^{2}$} & Basic & 0.15 & 0.57 \\
\cline { 2 - 4 } & Inclusive & 0.06 & 0.03 \\
\hline $\begin{array}{c}\text { Residual Standard } \\
\text { Error (RSE) (ha) }\end{array}$ & Basic & 345.3 & 246.8 \\
\hline
\end{tabular}

When comparing watershed area to riparian area (Figure 2.8 and Table 2.2), the basic riparian area shows a stronger relationship to watershed area $\left(\mathrm{R}^{2}=0.15\right)$ with a smaller residual standard error (RSE) when compared to inclusive riparian area $\left(\mathrm{R}^{2}=0.06\right)$. This is expected given both watershed area and basic riparian area are derived from elevation. It also indicates there may be another variable(s), possibly landform, influencing the extent of the inclusive riparian area given the decline in $\mathrm{R}^{2}$ and an increase in RSE. Evaluating the relationship between total stream length and riparian area exhibits the same relationship. 
The $\mathrm{R}^{2}$ value improves when comparing the relationship of basic riparian area regardless of landform to watershed area vs. total stream length $(0.15 \mathrm{vs.} 0.57)$ with a decline in RSE (345.3 vs. 246.8 ha) (Table 2.2). This indicates a stronger relationship between basic riparian area and total stream length compared to the influence of watershed area. However, the same relationship does not occur when evaluating inclusive riparian area. In fact, both the $\mathrm{R}^{2}$ and RSE indicate a weaker relationship between inclusive riparian area and total stream length. Again, indicating another variable, possibly landform with its associated wet soils and wetlands, influencing the inclusive riparian area.

Figures 2.8B and 2.9B show three points (enclosed in rectangle) which could be outliers. A closer evaluation shows these three points are peatland and contain over 3,000 ha $(7,413 \mathrm{ac})$ of adjacent wetlands and/or wet soils. Thus, illustrating wetlands and/or wet soils adjacent to the basic riparian area can be extensive even with shorter stream lengths. The above analyses support the hypothesis that landform influences the extent not only of basic riparian areas, but also inclusive riparian areas. This raises the question, do individual landforms influence riparian area to various degrees? Note: since only two watersheds are completely contained with the metamorphic landform, this landform is dropped from further analysis due to small sample size.

Table 2.3. $\mathrm{R}^{2}$ and RSE between watershed area and riparian area (basic and inclusive) for each landform types. Watersheds contained within the metamorphic landform are eliminated due to small sample size $(\mathrm{n}=2)$.

\begin{tabular}{cccccc}
\hline Landform & Number of & \multicolumn{2}{c}{$\mathbf{R}^{\mathbf{2}}$} & \multicolumn{2}{c}{ RSE (hectare) } \\
\cline { 3 - 6 } Type & Samples & Basic & Inclusive & Basic & Inclusive \\
\hline Peatland & 3 & 0.60 & 0.73 & 224.8 & 417.1 \\
\hline Outwash & 10 & 0.08 & 0.10 & 112.4 & 194.1 \\
\hline $\begin{array}{c}\text { Supraglacial } \\
\text { Drift } \\
\text { Complex }\end{array}$ & 12 & 0.46 & 0.51 & 154.1 & 320.1 \\
\hline Igneous & 7 & 0.37 & 0.08 & 160.5 & 340.2 \\
\hline Till Plain & 8 & 0.26 & 0.12 & 294.5 & 508.6 \\
\hline
\end{tabular}


Table 2.4. $\mathrm{R}^{2}$ and RSE between total stream length and riparian area for each landform types. Watersheds contained within the metamorphic landform are eliminated due to small sample size $(\mathrm{n}=2)$.

\begin{tabular}{cccccc}
\hline Landform & Number of & \multicolumn{2}{c}{$\mathbf{R}^{\mathbf{2}}$} & \multicolumn{2}{c}{ RSE (hectare) } \\
\cline { 3 - 6 } Type & Samples & Basic & Inclusive & Basic & Inclusive \\
\hline Peatland & 3 & 0.84 & 0.46 & 143.7 & 582.6 \\
\hline Outwash & 10 & 0.68 & 0.73 & 65.9 & 106.2 \\
\hline $\begin{array}{c}\text { Supraglacial } \\
\text { Drift } \\
\text { Complex }\end{array}$ & 12 & 0.84 & 0.75 & 84.3 & 228.9 \\
\hline Igneous & 7 & 0.47 & 0.11 & 147.8 & 334.7 \\
\hline Till Plain & 8 & 0.85 & 0.26 & 132.1 & 468.2 \\
\hline
\end{tabular}

The variation in area between basic riparian areas and inclusive riparian areas is caused by the presence of wetlands and/or wet soil conditions contiguous to the basic riparian area. In order to determine the differences on the extent of inclusive riparian area from each landform, two additional parameters are calculated:

- Riparian-Watershed Ratio: inclusive riparian area relative to watershed area; and

- Riparian-Stream Ratio: inclusive riparian area relative to total stream length.

The Riparian-Watershed Ratio (RW) indicates the percentage of a watershed mapped as riparian area. Higher values mean more riparian area exists per unit watershed. The Riparian-Stream Ratio (RS) indicates the extent of riparian area around streams. The means of both parameters by landform are listed in Table 2.5.

Table 2.5. Mean RW and mean RS for each landform. Watersheds contained within the metamorphic landform are eliminated due to small sample size $(n=2)$.

\begin{tabular}{ccc}
\hline Landform Type & RW (\%) & RS ( $\mathbf{m}^{\mathbf{2}} \mathbf{m} \mathbf{)}$ \\
\hline Peatland & 62.32 & 2147.90 \\
\hline Outwash & 8.07 & 211.91 \\
\hline $\begin{array}{c}\text { Supraglacial Drift } \\
\text { Complex }\end{array}$ & 8.38 & 216.92 \\
\hline Igneous & 12.83 & 155.37 \\
\hline Till Plain & 25.35 & 356.15 \\
\hline
\end{tabular}

The strongest relationship between basic riparian area and watershed area considering landform is peatland $\left(\mathrm{R}^{2}=60 \%\right.$ ) (Table 2.3 ) and increases to $73 \%$ for the inclusive riparian area. peatland topography is usually flat, extensive and in some instances even concave when associated with string-like patterns of hummocks. This facilitates large expansive riparian areas both basic and inclusive due to slow drainage across a relatively flat landscape. Therefore, both ratios $\left(\mathrm{RW}=62.32 \%\right.$ and $\left.\mathrm{RS}=2147.90 \mathrm{~m}^{2} / \mathrm{m}\right)$ in Table 2.5 are much higher compared to other landforms. In fact, peatland is also regarded as a 
wetland type in wetlands studies as it contains large amounts of organic matter accumulated in a water-saturated environment. Well defined stream channels are lacking in peatland within the study site and explain why $\mathrm{R}^{2}$ values decline between basic and inclusive riparian areas in Table 2.4. The stream channels which do exist have a strong relationship with basic riparian areas $\left(\mathrm{R}^{2}=84 \%\right)$. However, the relationship declines $\left(\mathrm{R}^{2}\right.$ $=46 \%$ ) for inclusive riparian area. Extensive wetlands and wet soils within the watershed explain the lower $\mathrm{R}^{2}$ value (Figure 2.10).

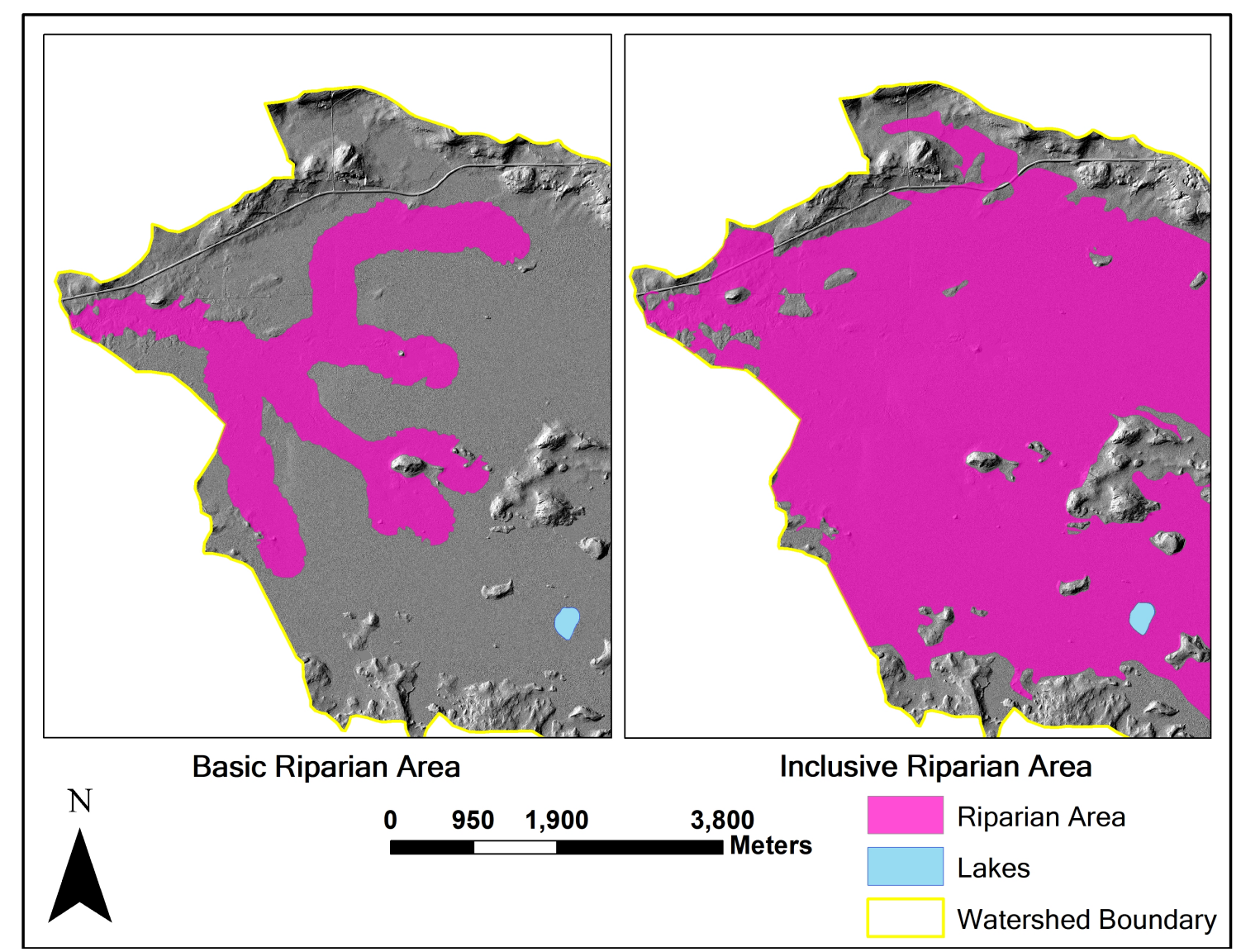

Figure 2.10. Example of basic and inclusive riparian areas in a peatland watershed (Headwaters Little Fork River).

Both basic and inclusive riparian areas located in an outwash show a small, almost nonexistent relationship to watershed area $\left(\mathrm{R}^{2}<1 \%\right)$ (Table 2.3). This landform exhibits highly variable and complex topography with poorly sorted and stratified sediments, resulting from sediment and debris choked glacial melt-water streams (Figure 2.11). This landform has three subtypes: an outwash fan adjacent to an ice margin complex and ice contact slope; an outwash plain consisting primarily of sand and gravel in well stratified layers; and a lowland outwash plain, which was initially a lake plain and later covered by outwash deposits with predominantly poorly or very poorly drained soils (Jerome, 2006). The numerous lakes with fixed width buffers contribute to the low ratios ( $\mathrm{RW}=8.07 \%$ and $\mathrm{RS}=211.91 \mathrm{~m}^{2} / \mathrm{m}$ ) in Table 2.5 . However, well defined stream channels have a 
stronger relationship with riparian area, and the well-drained soils explain the similar $\mathrm{R}^{2}$ values between basic riparian area $\left(\mathrm{R}^{2}=68 \%\right)$ and inclusive riparian area $\left(\mathrm{R}^{2}=73 \%\right)$ in Table 2.4.

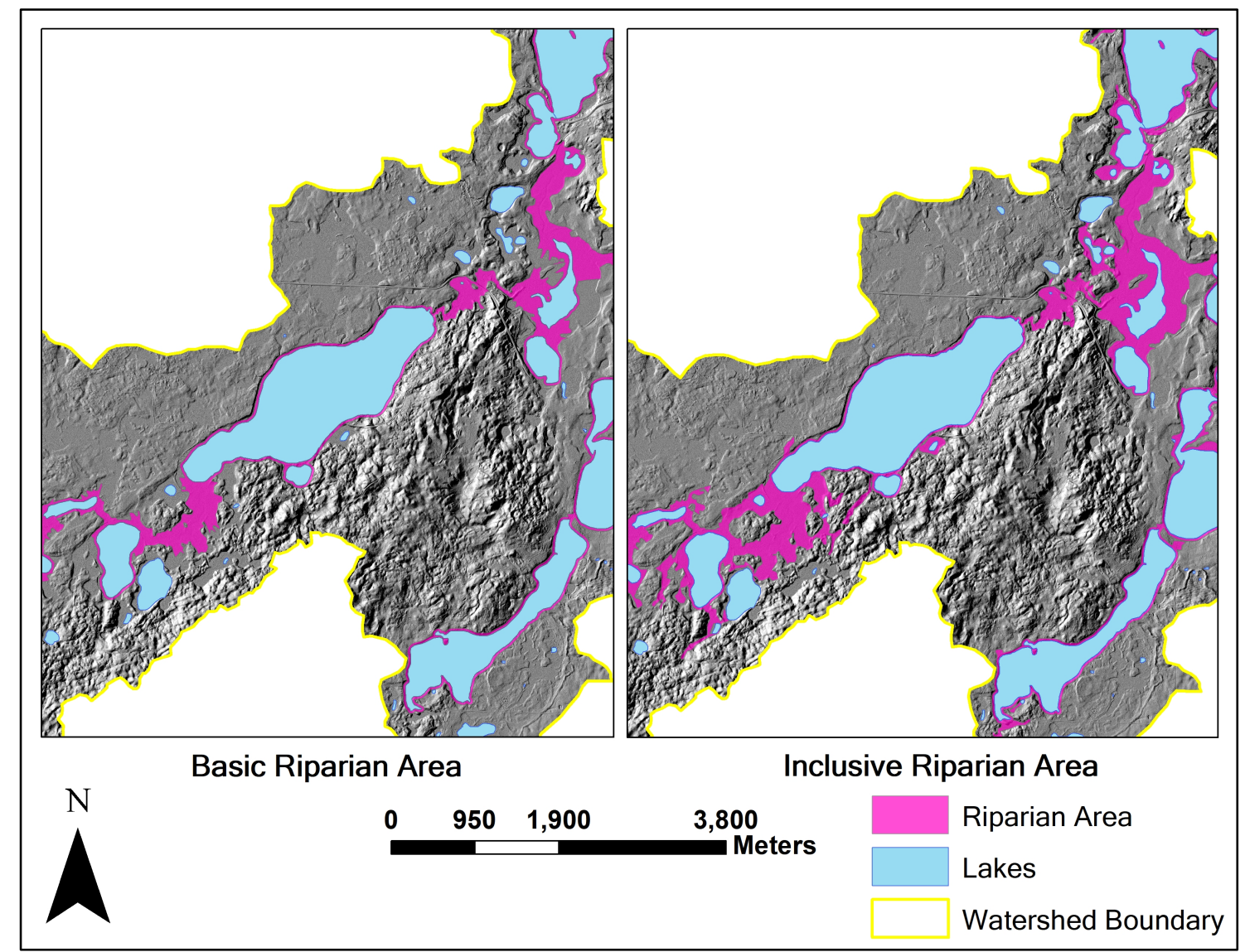

Figure 2.11. Example of basic and inclusive riparian areas in an outwash watershed (Big Deep Lake-Boy River).

Characteristic landforms created in a supraglacial drift complex are influenced by the sediment type, reworking process and climate. These landforms include hummocky moraines, kames and eskers (Schomacker and Benediktsson, 2018) which create a variable topography and stream channel width within a watershed (Figure 2.12). Narrower channels (kames) are created by melt water flowing between a melting glacier and higher landform. Hummocky moraines consist of large relative flat till plains intermixed with hills. Till plains are evident in Figure 2.11 where the delineated riparian buffers are wide. This highly variable terrain means a lower proportion of wetland and/or wet soils are contiguous along the stream channels and explains the low ratios (RW $=$ $8.38 \%$ and $\mathrm{RS}=216.92 \mathrm{~m}^{2} / \mathrm{m}$ ) (Table 2.5). Supporting this assessment are the similar $\mathrm{R}^{2}$ values to watershed area in Table 2.3 (46\% for the basic riparian area and $51 \%$ for the inclusive riparian area). In addition, narrow, well defined stream channels limit the area of the riparian buffers and, explain the relatively strong relationship between basic 
riparian area and stream length $\left(\mathrm{R}^{2}=84 \%\right)$ in Table 2.4 . Where the till plain occurs and riparian buffers become wider, the $\mathrm{R}^{2}(75 \%)$ declines.

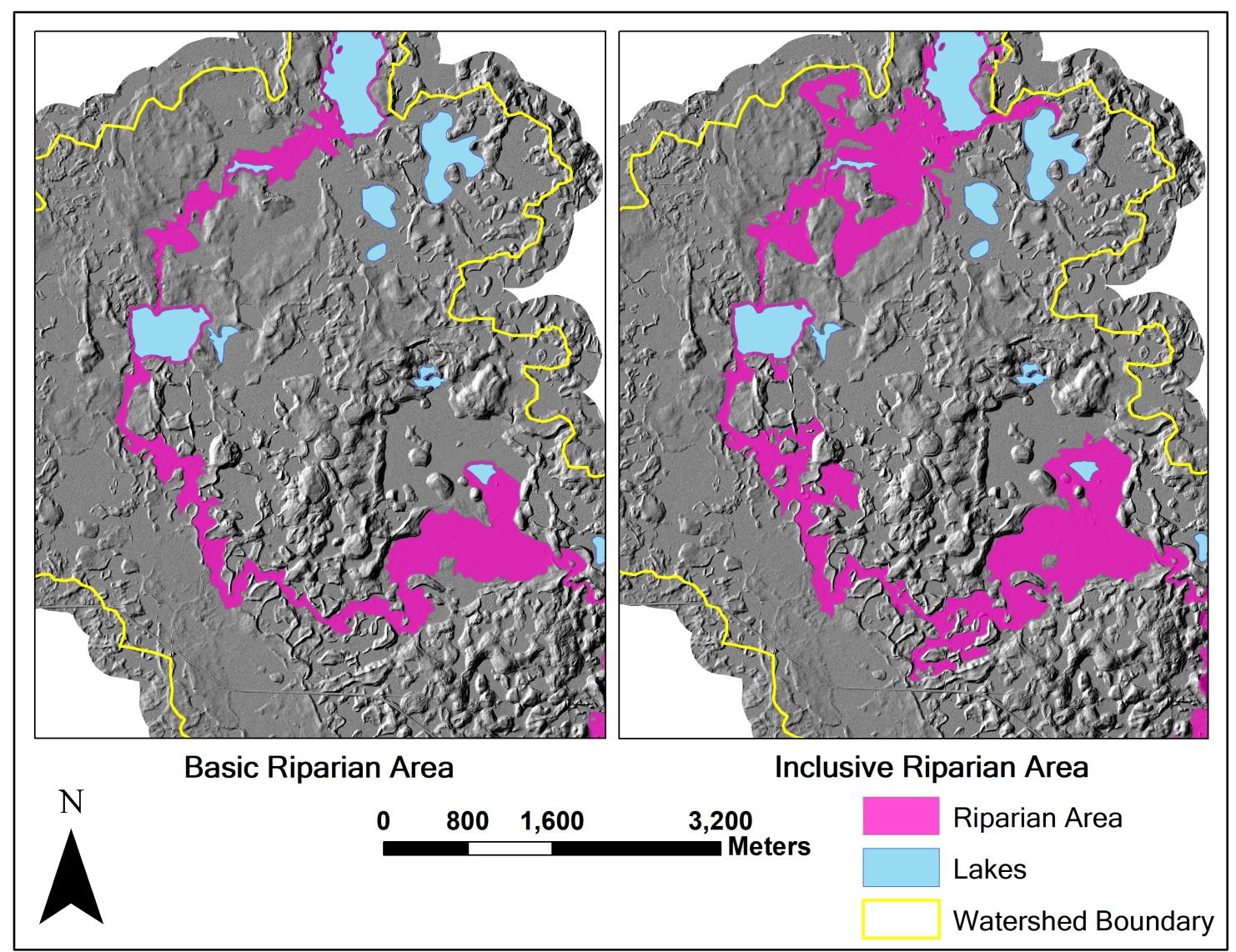

Figure 2.12. Example of basic and inclusive riparian areas in a supraglacial drift complex watershed (Wagner Creek).

Igneous landform is formed from cooling and consequent solidification of magma. Theses massive batholithic intrusions are topographically expressed as domelike hills and are important landforms in northeastern Minnesota. In humid or temperate regions, the tops of the hills are gently rounded, and the side slopes are relatively steep, producing a "knobby" topography. Dendritic drainage patterns are common (Integrated Publishing, 2003) with well defined, narrow stream channels, linked to numerous lakes (Figure 2.13). These stream channels are also erosion resistant and influence the $\mathrm{R}^{2}$ value of $37 \%$ between basic riparian area and watershed area (Table 2.3) followed by the drop in $\mathrm{R}^{2}$ $(8 \%)$ when adjacent wetlands and wet soils are considered in the inclusive riparian areas. The low ratios $\left(\mathrm{RW}=12.83 \%\right.$ and $\left.\mathrm{RS}=155.37 \mathrm{~m}^{2} / \mathrm{m}\right)($ Table 2.5$)$ are also due to the confinement of the stream and its associated floodplain. The stream channels have a stronger relationship with basic riparian areas $\left(\mathrm{R}^{2}=47 \%\right)$ in Table 2.4. Because of the variation in upland soil drainage condition, the relationship declines between inclusive riparian area and stream length $\left(\mathrm{R}^{2}=11 \%\right)$. 


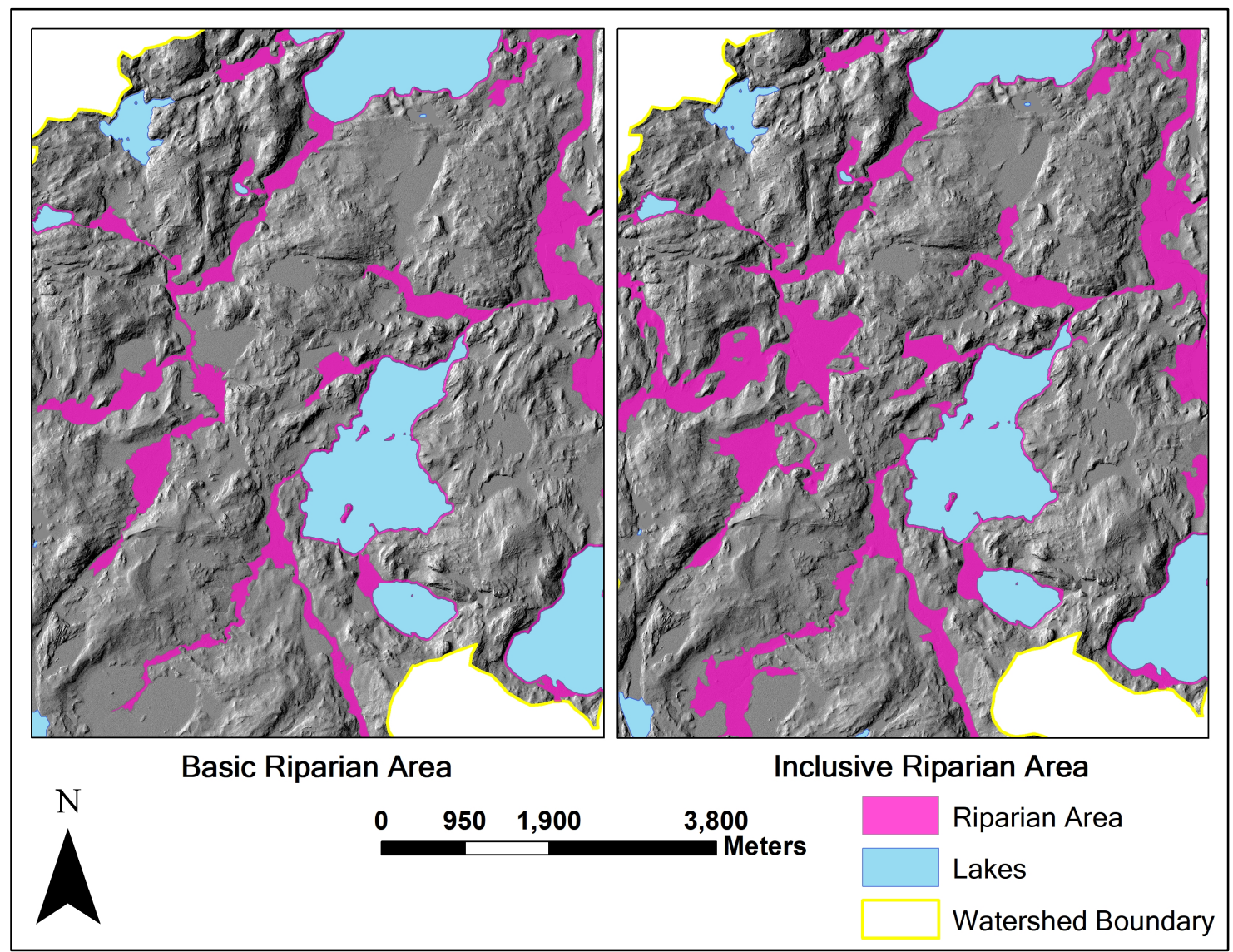

Figure 2.13. Example of basic and inclusive riparian areas in an igneous landform watershed (Boulder River).

Till Plains are created when debris loaded ice detaches from the main glacier, melts in place, and deposits carried sediments. It consists of a random mixture of different sized angular rock fragments in a matrix of fine grained, sand to clay sized fragments produced by abrasion within the glacier (Figure 2.14). The topography varies from rolling to flat depend on the bedrock (Nelson, 2015). Like peatland, the wider stream channels on the relatively flat topography explain the higher ratios $(\mathrm{RW}=25.35 \%$ and $\mathrm{RS}=$ $356.15 \mathrm{~m}^{2} / \mathrm{m}$ ) than the rest of landforms in Table 2.5 . The well-defined stream channels, unlike peatland, have the strongest relationship with basic riparian area $\left(\mathrm{R}^{2}=85 \%\right)$. However, the relationship declines $\left(\mathrm{R}^{2}=26 \%\right)$ for inclusive riparian area in Table 2.4. Different soil textures from upstream to downstream, which affect the drainage condition, explain the lower $\mathrm{R}^{2}$ value. The extent and complexity of the stream networks vary in different watersheds on till plain as well. For example, an extensive watershed might have a much shorter and/or less complex stream network than another smaller watershed. Therefore, the extent of riparian area changes regardless of the watershed area, which explains the weak relationship $\left(\mathrm{R}^{2}=26 \%\right)$ value in Table 2.3. The relationship declines $\left(\mathrm{R}^{2}=12 \%\right)$ because of the changing soil drainage conditions as well. 


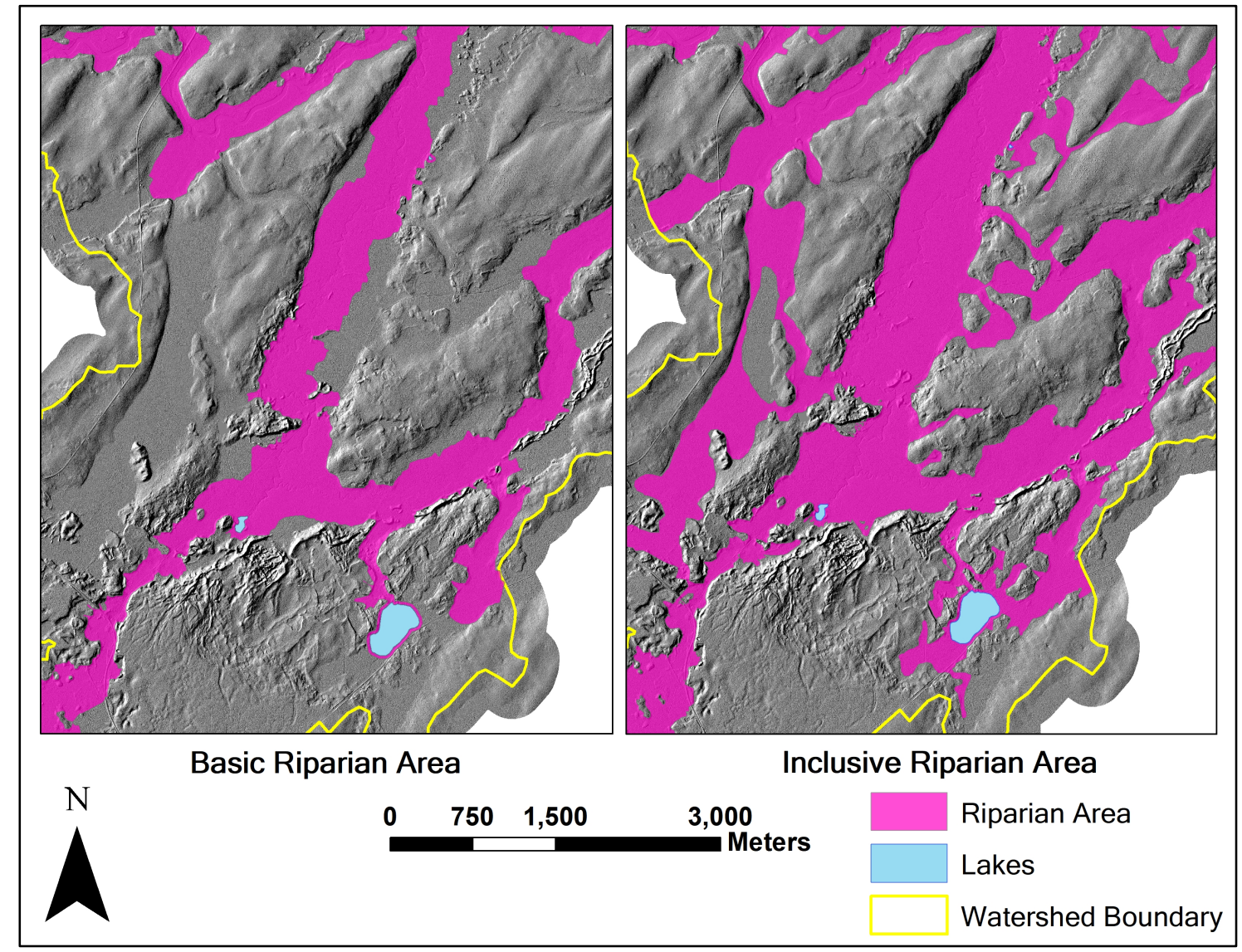

Figure 2.14. Example of basic and inclusive riparian areas in a till plain watershed (South Branch Whiteface River).

\subsubsection{Complexity Indicators}

Analyses of the structural composition and complexity of both the basic and inclusive riparian buffer zones are accomplished utilizing Patch Analyst (Rempel et al., 2012,). Patch Analyst is chosen over FRAGSTATS due to its compatibility with raster datasets in a GDB. Landscape metrics are calculated for each riparian buffer to provide measures of landscape structure to determine if geomorphological landform influences the structure and complexity of the riparian area. Patch Analyst was developed by the Spatial Ecology Program at the Centre for Northern Forest Ecosystem Research, with programming support from the Thunder Bay Geomatics Service Centre, Ontario Ministry of Natural Resources, Thunder Bay, ON. It is a free spatial pattern analysis extension for ArcMap and ArcGIS Pro. Metrics used for this study include:

- Total Edge (TE): perimeter of the riparian buffer zone;

- Edge Density (ED): TE to the area of riparian buffer zone (Area); and 
- Mean Shape Index (MSI): TE to the square root of the Area and adjusted to a circular standard.

$$
\begin{gathered}
\mathrm{ED}=\frac{\mathrm{TE}}{\text { Buffer Area }} \\
\mathrm{MSI}=\frac{\mathrm{TE}}{2 \sqrt{\text { Buffer Area } * \pi}}
\end{gathered}
$$

TE, as one of several potential calculated edge metrics, is not spatially explicit (McGarigal, 1995). Greater TE of a riparian buffer may not represent a more complex boundary, because the area of the riparian buffer is not considered. ED is spatially explicit ( $\mathrm{m} / \mathrm{ha}$ ) and standardizes riparian buffer perimeter to its associated riparian buffer area. Therefore, ED of the riparian buffer can effectively represent the complexity of its boundary. MSI determines the average perimeter to area ratio and calculates how circular the shape is. The smaller MSI, can be interpreted as the overall shape closest to a circle. These two metrics allow comparison between riparian areas of different sizes and contained within different landforms. The mean TE, ED and MSI of both basic and inclusive riparian areas of each landform are presented in Table 2.6.

Table 2.6. Mean values of the complexity indicators vs. landform types.

\begin{tabular}{ccccccc}
\hline \multirow{2}{*}{$\begin{array}{c}\text { Landform } \\
\text { Type }\end{array}$} & \multicolumn{2}{c}{ TE $\mathbf{( k m )}$} & \multicolumn{2}{c}{ ED (m/ha) } & \multicolumn{2}{c}{ MSI } \\
\cline { 2 - 7 } & Basic & Inclusive & Basic & Inclusive & Basic & Inclusive \\
\hline Peatland & 42.77 & 162.82 & 80.67 & 35.61 & 5.13 & 6.78 \\
\hline Outwash & 91.20 & 103.07 & 369.25 & 304.22 & 16.00 & 15.21 \\
\hline $\begin{array}{c}\text { Supraglacial } \\
\text { Drift Complex }\end{array}$ & 124.41 & 169.12 & 356.70 & 287.71 & 17.90 & 18.23 \\
\hline Igneous & 289.31 & 328.90 & 379.45 & 312.61 & 29.36 & 28.40 \\
\hline Till Plain & 150.40 & 213.82 & 135.77 & 123.28 & 12.61 & 14.33 \\
\hline
\end{tabular}

The ED of the basic riparian areas is always greater than the ED of inclusive riparian areas for all landforms, because the boundaries of the basic riparian areas are solely determined by the 1-meter DEM and the 50-year flood heights, which maps subtle topographic changes in detail and create a more detailed, complex boundary. Soils and wetlands polygons, however, are mapped at smaller scales, and create polygons with smoother boundaries. This follows the basic cartographic principle that the smaller the scale, the smoother the boundary for an object. The more wet soils and/or wetlands contiguous to the basic riparian area, the greater the ED difference between the two types riparian areas. Another condition affecting ED is the riparian area may contain multiple hollow areas (bubbles) (Figure 2.13), which represent lakes or upland areas, including islands in lakes. The edges of these features also contribute to the TE. The RBDM generates riparian buffers around the lake with a $30.48 \mathrm{~m}$ (100 feet) buffer. Without considering the adjacent wetlands and/or wet soils, the riparian buffers around lakes are usually narrower than the riparian area along the watercourse. In other words, it 
determines a smaller area around each unit of water, but a higher ED since both lake perimeter and "bubble" perimeters are included in the ED calculation. The "bubbles" perimeter contribution explains the greatest ED of the basic riparian area of igneous $(379.45 \mathrm{~m} / \mathrm{ha})$, and the similar ED values of the basic riparian area of outwash $(369.25$ $\mathrm{m} / \mathrm{ha})$.

The ED values of inclusive riparian area of igneous $(312.61 \mathrm{~m} / \mathrm{ha})$ and outwash $(304.22$ $\mathrm{m} / \mathrm{ha}$ ) are close, which demonstrate the boundary complexity can be similar on landforms with formations and landscape characteristics. The MSI, however, indicate greater difference between igneous and outwash for both basic and inclusive riparian areas. The "knobby" topography and Dendritic drainage patterns of igneous are different from the three components of the outwash landform.

There are fewer lakes in the supraglacial drift complex compared to igneous or outwash. However, the ED of basic riparian area $(356.70 \mathrm{~m} / \mathrm{ha})$, which is mainly caused by the highly curved boundaries, is similar in those two landforms. With fewer wet soils and/or wetlands adjacent to the basic riparian area, the greater difference between ED values for basic vs. inclusive riparian area $(287.71 \mathrm{~m} / \mathrm{ha})$ also indicates curved boundaries affect ED more than other characteristics. The curved boundaries are formed by differing erosion rates of the soils along the stream, such as sandstone, shale and limestone.

The ED of basic riparian area on peatland $(80.67 \mathrm{~m} / \mathrm{ha})$ is lowest because of its flat topography and water-saturated environment, which generate riparian buffers with very smooth boundaries along the streams $(\mathrm{MSI}=5.13)$. The inclusive riparian areas on peatland contain extensive of wet soils and wetlands which explain the decline in ED $(35.61 \mathrm{~m} / \mathrm{ha})$. The boundary of those wet soils and wetlands are not as smooth as the basic riparian area, but the overall shapes are more compact than all other landforms $(\mathrm{MSI}=6.78)$.

There are similarities between till plain and peatland as discussed before, such as wider stream channels and relatively flat topography with few lakes. These characteristics generate smoother riparian area boundaries. However, the stream channels are well defined on till plain, and the stream networks are more complex than peatland, which explain the ED and MSI higher than peatland, but lower than other landforms $(\mathrm{ED}=$ $135.77 \mathrm{~m} / \mathrm{ha}$ and MSI = 12.61). Even though there are various amounts of wet soils and/or wetlands adjacent to the basic riparian area from upstream to downstream, which increase the MSI to 6.78, the boundary complexities of wet soils and wet lands are similar to the basic riparian area, explain the similar ED of inclusive riparian area (123.28 $\mathrm{m} / \mathrm{ha})$. 


\subsection{Conclusions}

Based on the statistical analysis on the above-mentioned parameters, influences of geomorphic landform on riparian areas is shown. The relationships between the riparian buffer area (both basic and inclusive) and the watershed extent, and between the riparian area and the stream length can be evaluated by categorizing the samples by landform type. Landforms and their associated characteristics influence both extent and shape complexity of riparian areas. The study provides an analytical perspective of the BMPs for wetlands and stream protection using geospatial data, which could be applied into other areas and different landforms. For example, the workflow of this research could be applied in the Western or Southeastern United States, where the formation characteristics of landforms and the hydrological conditions are very different from LMF. As long as the quality of geospatial data are guaranteed, more potential relationships between the riparian area and landforms may be discovered with further research.

The riparian area outputs can be used in multiple applications when overlaid with different spatial data, such as Land Use/Land Cover evaluation and wildlife habitat protection. In the meanwhile, this study builds up a new connection between geomorphology, hydrology and wetlands management, using riparian area as the study object. With additional study areas of various landforms getting involved in the future, the parameters discussed in this study could provide better support for applications where landform plays an important role influencing riparian area.

\subsection{References}

Abood, S. A., 2019. National Riparian Areas Base Map. 2019 ESRI User Conference. Paper presentation \#1361, Session: Forest Analysis \& Modeling (Thursday July 11th). July 8 - July 12, 2019. San Diego Convention Center. https://storymaps.arcgis.com/stories/8cd69adaaaf541c78f8d867f0ec6b6ef

Abood, S. A., 2011. Modeling and Classifying Variable Width Riparian Zones Utilizing Digital Elevation Models, Flood Height Data, Digital Soils Data and National Wetlands Inventory: A New Approach for Riparian Zone Delineation. PhD. Dissertation, Michigan Technological University, Houghton, MI. 111 p.

Abood, S. A., and Maclean, A. L., 2018. Riparian Buffer Delineation Model for ArcPro. Version 5.1. www.riparian-solutions.

Abood, S. A., Maclean, A. L., and Mason, L. A., 2012. Modeling Riparian Zones Utilizing DEMS and Flood Height Data via GIS. Photogrammetric Engineering and Remote Sensing. 78(3): 259-269. 
Albert, Dennis A. 1995. Regional landscape ecosystems of Michigan, Minnesota and Wisconsin: a working map and classification. General Technical Report NC-178. St. Paul, MN: U.S. Dept. of Agriculture, Forest Service, North Central Forest Experiment Station.

Bedient, P.B., and Huber, W. C., 2002. Hydrology and Floodplain Analysis, Third edition, Prentice Hall, New Jersey, 763 p.

Cleland, D. T., Avers, P. E., McNab, W. H., Jensen, M. E., Bailey, R. G., King, T., and Russell, W. E., 1997. National Hierarchical Framework of Ecological Units. Published in, Boyce, M. S., Haney, A., ed., 1997. Ecosystem Management Applications for Sustainable Forest and Wildlife Resources. Yale University Press, New Haven, CT. pp. 181-200.

Ding, H., 2020. The Influence of Landforms and Sampling Approaches on Riparian Buffer Area and Complexity. PhD. Dissertation, Michigan Technological University, Houghton, MI. 87 p.

Hanowski, J., Danz, N., and Lind, J., 2007. Breeding Bird Response to Riparian Forest Management: 9 Years Post-Harvest. Forest Ecol. Manage. 241 (2007), pp. 272-277.

Hoffman, P. F., and Bowring, S. A., 1984. Short-lived 1.9 Ga continental margin and its destruction, Wopmay Orogen, north west Canada: Geology, v. 12, p. 68-72.

Ilhardt, B. L., Verry, E. S., and Palik, B. J., 2000. Defining riparian areas. In: Verry, E.S.; Hornbeck, J.W.; Dolloff, C.A., eds. Riparian management in forests of the continental eastern United States. Boca Raton, FL: Lewis Publishers: 23-42.

Integrated Publishing. 2003. Geologic Analysis. URL: http://www.tpub.com.

Jerome, D. S., 2016. Landforms of the Upper peninsula. USDA Natural Resources Conservation Service. 56 pages.

Lillesand, T. M., Kiefer, R. W., Chipman, J. W., 2015. Remote Sensing and Image Interpretation (Seventh Edition). John Wiley \& Sons, Hoboken, USA, p. 736.

Mason, L., 2007. GIS Modeling of Riparian Zones Utilizing Digital Elevation Models and Flood Height Data: An Intelligent Approach. M.S. Thesis, Michigan Technological University, Houghton, Michigan, 75p.

Macdonald, E., Burgess, C. J., Scrimgeour, G. J., Boutin, S., Reedyk, S., and Kotak, B., 2003. Should Riparian Buffers be Part of Forest Management Based on Emulation of Natural Disturbance? Forest Ecol. Manage., 187 (2003), pp. 185-196.

Management in Forests of the Continental Eastern United States. Lewis Publishers, New York. pp. 233-254. 
McGarigal, K., 2015. FRAGSTATS: Spatial Pattern Analysis Program for Categorical Maps. UMass Landscape Ecology Lab, University of Massachusetts Amherst, Amherst, Massachusetts.

Minnesota Department of Natural Resources, 2016. Ecological Classification System: Laurentian Mixed Forest Province. URL: https://www.dnr.state.mn.us/ecs/212/index.html

Minnesota Geospatial Information Office, 2012. LiDAR Elevation Data for Minnesota. URL: http://www.mngeo.state.mn.us/chouse/elevation/lidar.html

Nelson, S. 2015. Physical Geology: Glaciers and Glaciation. Tulane University, Earth \& Environmental Science 1110.

Palik, B., Zasada, J., and Hedman, C., 2000. Ecological Considerations for Riparian Silviculture. In Verry, E. S., Hornbeck, J. W., and Dolloff, C. A. eds. Riparian

Rempel, R.S., D. Kaukinen., and A.P. Carr., 2012. Patch Analyst and Patch Grid. Ontario Ministry of Natural Resources. Centre for Northern Forest Ecosystem Research, Thunder Bay, Ontario.

Riparian Science Technical Committee MN, 2007. Analysis of the Current Science behind Riparian Issues. Minnesota Forest Resources Council.

Schomacker, A., and Benediktsson, I. O., 2018. Chapter 6 - Supraglacial Environment. Past Glacial Environments (Second Edition), pp. 159-179.

Skally, C., and Sagor, E., 2001. Comparing Riparian Management Zones to Riparian Areas in Minnesota: a Pilot Study. Minnesota Forest Resources Council, Research Report 1001.

Soil Survey Staff. The Gridded Soil Survey Geographic (gSSURGO) Database for Minnesota. United States Department of Agriculture, Natural Resources Conservation Service. Available online at https://gdg.sc.egov.usda.gov/. November 16, 2015 (FY2016 official release).

Thomas, Z., 2014. Geomorphology of Minnesota. Minnesota Department of Natural Resources.

U. S. Fish and Wildlife Service. 2017. National Wetlands Inventory website. U.S. Department of the Interior, Fish and Wildlife Service, Washington, D.C. http://www.fws.gov/wetland/.

United States Geological Survey, 2017. USGS National Hydrography Dataset. URL: http:// nhd.usgs.gov/index.html. 
U.S. Geological Survey, 2016, National Water Information System data available on the World Wide Web (USGS Water Data for the Nation), accessed [June 10, 2012], at URL [http://waterdata.usgs.gov/nwis/].

United States Geological Survey (USGS), 1997. Standards for Digital Elevation Models, part I. National Mapping Program Technical Instructions, U.S. Department of Interior. 11 pp. 


\section{Analysis of Distance Sampling Approaches on Riparian Buffer Area and Complexity}

\subsection{Introduction}

A riparian area is a zone of interaction between aquatic and terrestrial ecosystems along streams, lakes, wetlands, and other water bodies. Riparian areas affect water features, and in turn, are affected by them. These zones perform critical ecological functions that link aquatic and terrestrial ecosystems (Riparian Science Technical Committee MN, 2007). Delineating accurate riparian management zones (RMZs), often utilized in Best Management Practices (BMPs) for wetland and stream protection, is important. These zones effectively moderate microclimate at the local ecosystem scale, and trap sediments and nutrients between uplands and waterbodies. Thus, multiple conservation goals are achieved, such as stream bank stabilization, flood attenuation, and maintenance of wildlife movement corridors.

Fixed width RMZs or buffers, which are simple to delineate, implement and monitor, were regarded as the standard of practice for many years to protect waterbodies from adverse impacts of development, mining, timber harvesting and agricultural runoff. Before the commercialization and widespread use of Global Positioning Systems (GPS), a fixed width buffer was the easiest to map and monitor on the ground. However, Palik et al. (2000) showed fixed width RMZs were inadequate and inaccurate as these buffers cannot replicate natural or true riparian zone boundaries since they have no functional relationship to the naturally varying watercourse and its associated land cover. In addition, research conducted by Skally and Sagor (2001) in northern Minnesota concluded riparian buffer boundaries were, on average, 2.5 times farther from the water course than the BMP fixed width buffer. Research by Macdonald et al. (2003) and Hanowski et al. (2007) supports these conclusions.

In developing a variable width RMZ delineation model, two factors must be considered: the watercourse and its associated floodplain. These components must be included in a valid delineation model. Research by Ilhardt et al. (2000), determined the 50-year floodplain was the optimal hydrologic descriptor of a RMZ. By hydrologically defining a RMZ as occurring at the 50-year flood height and incorporating digital elevation data (DEM) with the spatial modeling capabilities of ArcGIS, the Riparian Buffer Delineation Model (RBDM) was developed and implemented (Mason, 2007; Abood and Maclean, 2012). The RBDM is used extensively by various government agencies, NGOs, academic programs, private companies, and individuals. It has undergone rigorous validation for accurate boundary delineation (Abood, 2019). Details on RBDM functionality are found in Abood (2011) and Abood and Maclean (2012).

Geographic information systems (GIS) commonly use planar coordinates to calculate distance and area and disregard changes in elevation, slope or the earth's curvature. The use of 2D Cartesian coordinates ensures the distance between two locations is the shortest 
distance between them and performs well with vector data. Analyzing raster data with a planar coordinate system uses Euclidian distance and determines each cell's (pixel's) relationship to a source or set of sources based on straight line distance.

The RBDM requires all spatial data to be registered to a planar projected coordinate system. Distances for stream segments and locations of the sample points are calculated using the planar X, Y coordinates associated with the UTM coordinate system for this study. However, slope is an important component of every stream segment and introduces a discrepancy between the planar coordinate distance and the actual ground distance (Figure 3.1). Hence, the question arises as to whether or not planar distance is sufficiently accurate to quantify and characterize the riparian buffer, or would buffer delineation accuracy be improved using equally spaced ground distance intervals? Answering this question, requires answering another question as well. What impact does the spatial resolution of the DEM have on ground distance vs. planar distance calculations? Coarser spatial resolution, such as a $30 \mathrm{~m}$ DEM, does not discern subtle changes in elevation and impacts riparian area calculations (Abood, 2011). However, $1 \mathrm{~m}$ or finer resolution DEMs preserves subtle and finer changes in elevation and slope.

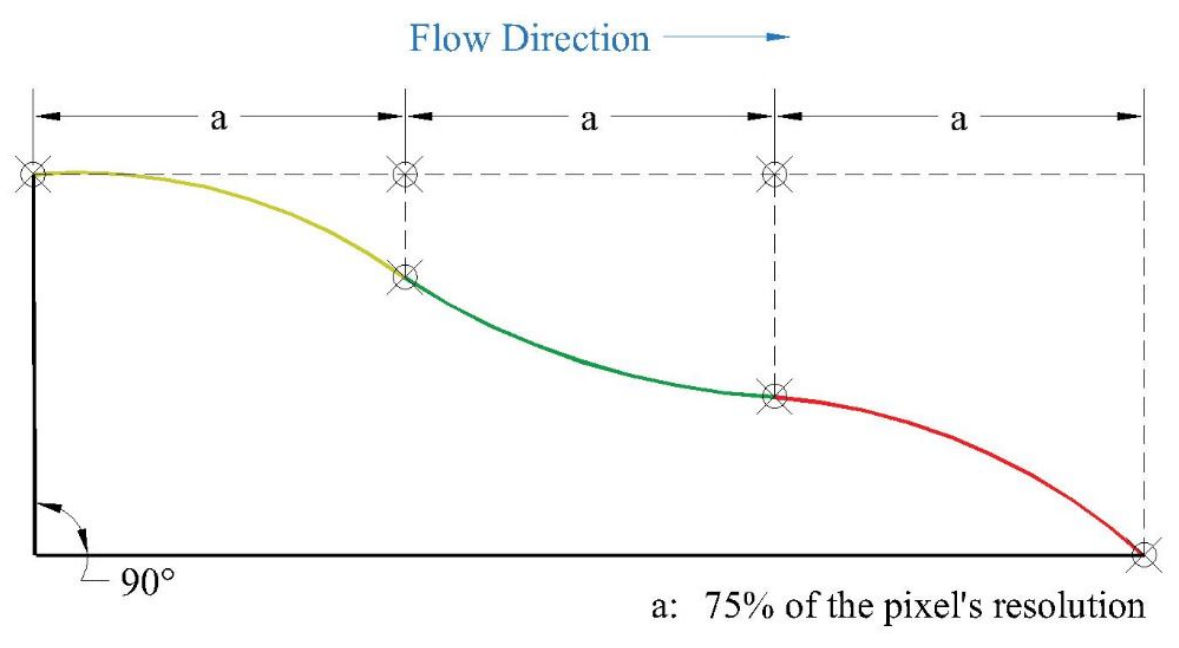

Figure 3.1. Side view of surface runoff with sample points at a regular, planar coordinate interval, comparing to varying ground distances due to slope.

\subsection{Study Site Selection Criteria}

A study area of varying geomorphology minimally influenced by development and urbanization is preferred since naturally occurring changes in elevation and slope are required. The Upper Midwest has undergone extensive glaciation and contains a wide variety of distinguishable landforms not found elsewhere in the United States which provide a unique look at a diversity of topography in a relatively small geographic area. 
Additionally, the study area must have standardized, consistent, high quality spatial data which are required by the RBDM. This includes fine spatial resolution $(<10 \mathrm{~m})$ digital elevation modes (DEMs), hydrography data, such as the National Hydrography Data (NHD), wetlands maps, such as the National Wetlands Inventory (NWI) or newer, and detailed soils information, such as the gSSURGO. Land use/cover data is also desirable, but not required. Finer spatial resolution data is required to map detailed topographic changes across different landforms. Data with known positional errors is necessary since these carry through to the location of riparian boundaries (Abood, 2019). There also needs to be an adequate number and good distribution of stream gauges across the area since 50-year flood height is a required input into the RBDM. Previous studies have shown this to be the most difficult data requirement to achieve (Abood and Maclean, 2018), and gauges outside of a watershed may need to be utilized.

An area in northeastern Minnesota (Figure 3.2) is selected which meets the above criteria. Distinct landforms based on the landform map by Thomas (2014) exist which have sufficiently large area and wholly contain National NHD HUC12 watersheds. Six landforms, representing the dominant formation characteristics of the area, are utilized for the study, including:

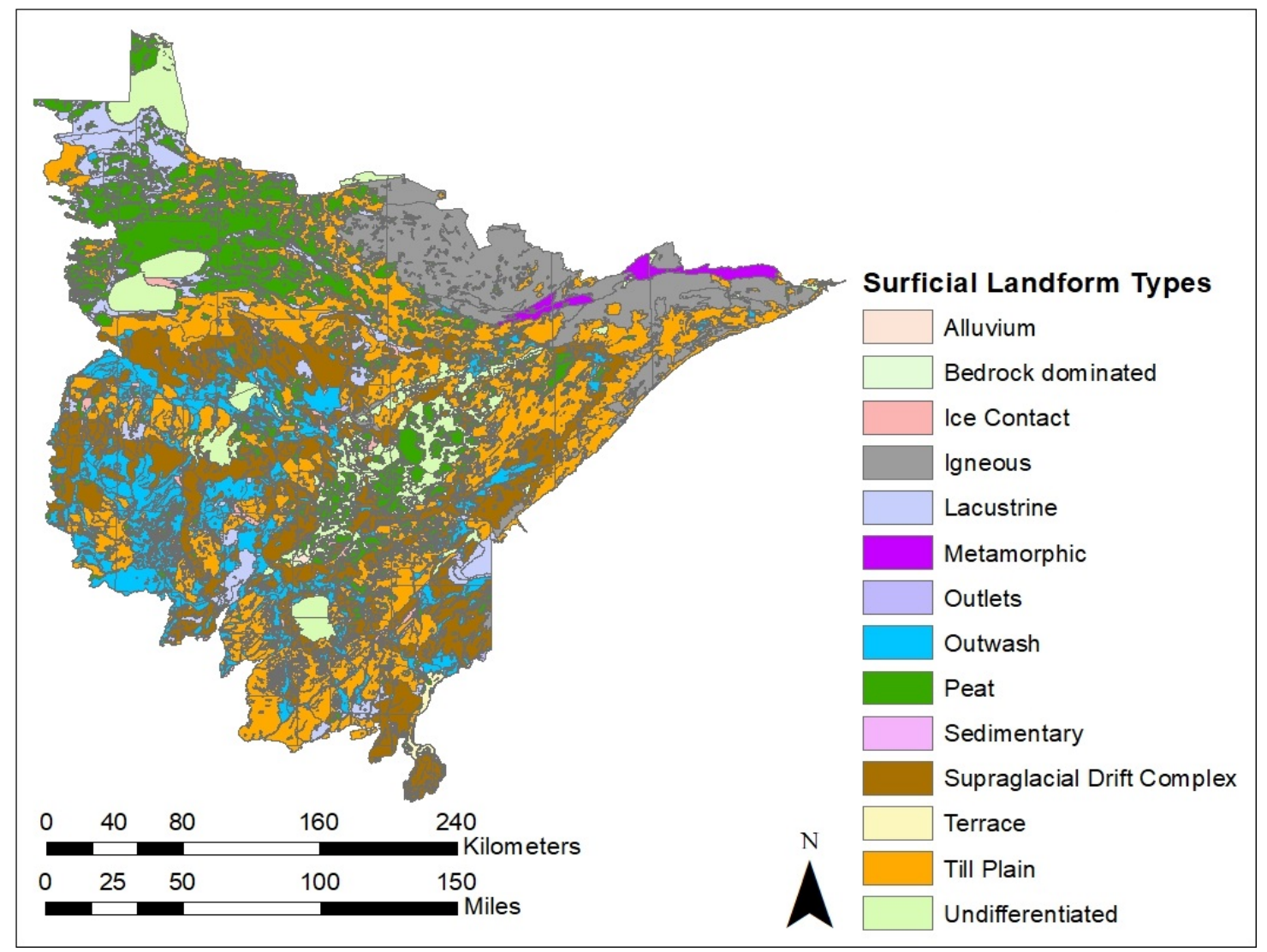

Figure 3.2. Surficial landform types for northeast Minnesota within the LMF Province. Data source: Minnesota Department of Natural Resources and USGS National Hydrography Dataset. Coordinate system: NAD 1983 UTM Zone 15N. 
- Supraglacial Drift Complex: composed of coarsely graded and complex glacial sediments;

- Igneous: formed from cooling and consequent solidification of magma;

- Till Plain: created when debris loaded ice detached from the main glacier, melted in place, and deposited carried sediments;

- Outwash: formed from glacier sediments deposited by meltwater at the terminus of a glacier;

- Metamorphic: created from the transformation of underlying rocks subjected to high temperatures and pressures; and

- Peatland: formed from decomposed and decayed wetland vegetation creating massive organic soil deposits accumulated over thousands of years (Thomas, 2014).

In order to analyze the two sampling approaches on different stream orders with, one HUC12 watershed was selected from each landform. The watersheds were evaluated to have continuous stream orders with few lakes. The RBDM places a consistent 100 feet buffer around each lake based on the research completed by Ilhardt et al. (2000), and do not consider changes in topography or other landscape characteristics. In order to minimize anthropogenic influences, sample watersheds did not include extensively ditched/drained areas or mining operations.

\subsection{Methodology}

Within the study site, 23 USGS stream gauges with a minimum of 10 years of both field measurements and annual statistics are selected for flood height calculations (Figure 3.3). These calculations are performed using the procedure developed by Mason (2007). Overlaying the stream gauges' coordinates with landform type and NHD stream order information ascertains the landform and stream order for each gauge. For each landform type, a specific 50-year flood height regression equation is calculated for stream order. For example, within the outwash landform, 50-year flood heights are plotted for each represented stream order (Figure 3.4). Using the regression equation with the highest $\mathrm{R}^{2}$ value, a 50-year flood height is determined for each stream order. The flood heights are added as an attribute field to the stream feature class based on the stream order rank (Table 3.1). 


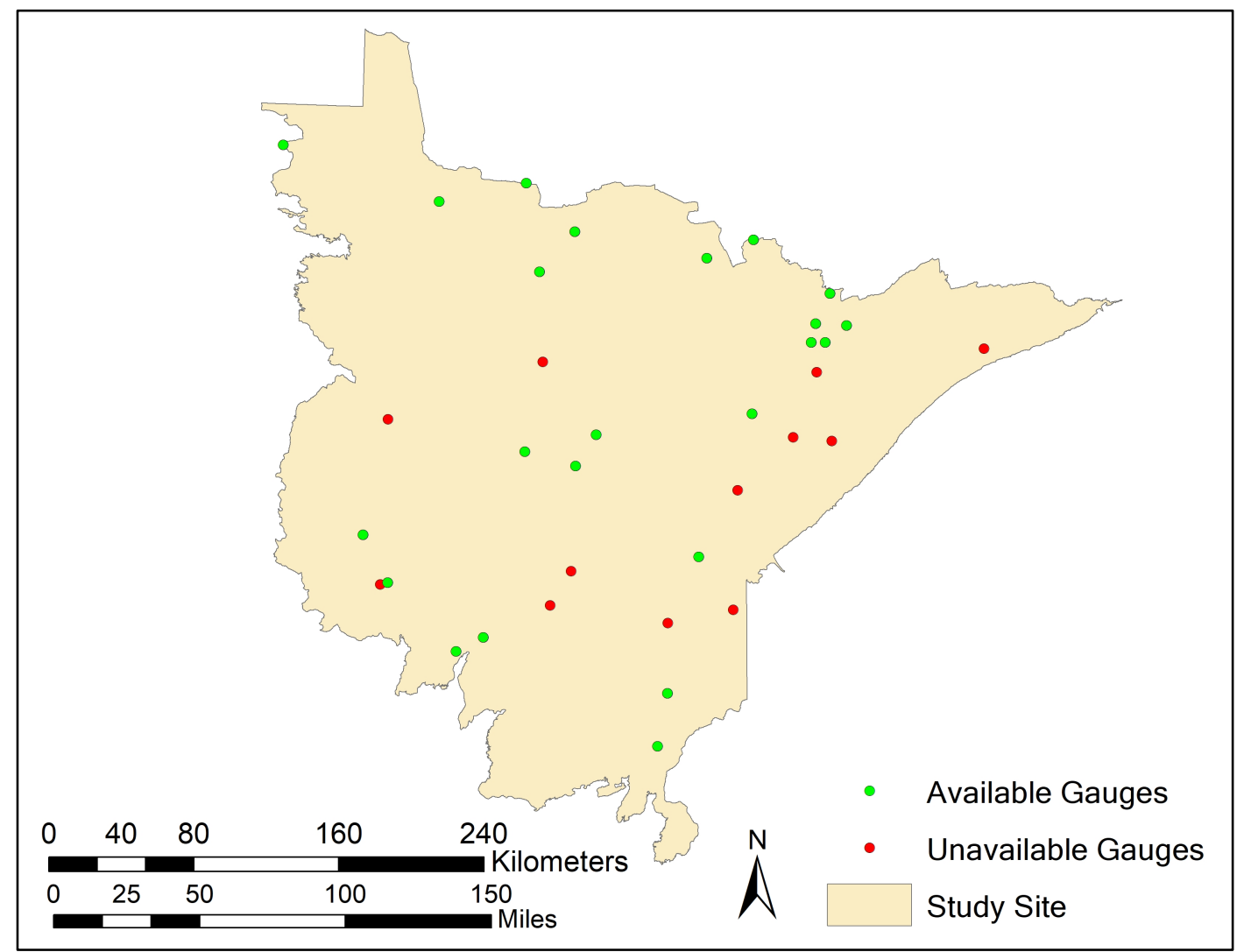

Figure 3.3. Locations of the stream gauges in the study site. Data source: Minnesota Department of Natural Resources and USGS Water Data. Coordinate system: NAD 1983 UTM Zone $15 \mathrm{~N}$.

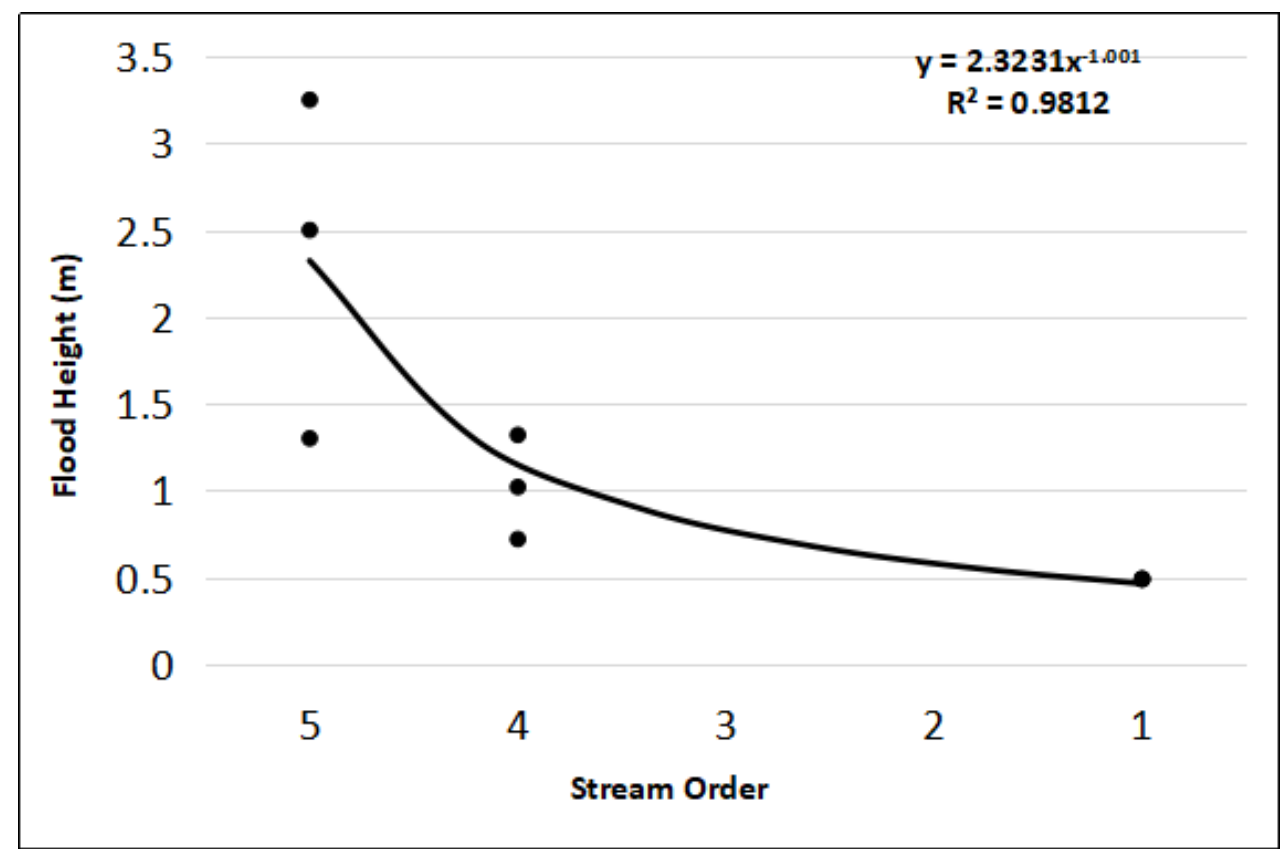

Figure 3.4. Example of flood height regression plots for the outwash landform. 
Table 3.1. Example of flood heights for various stream orders for the outwash landform.

\begin{tabular}{cc}
\hline Stream Order & Flood Height $(\mathbf{m})$ \\
\hline 5 & 2.32 \\
\hline 4 & 1.16 \\
\hline 3 & 0.77 \\
\hline 2 & 0.58 \\
\hline 1 & 0.46 \\
\hline
\end{tabular}

An individual file geodatabase (GDB) is created for each watershed. Lidar derived 1meter DEMs available from the Minnesota IT Services Geospatial Information Office (https://www.mngeo.state.mn.us/chouse/) are imported into the GDB as raster datasets, and the NHD data are imported as feature classes. The scale of the NHD data $(1: 24,000)$ is not fine enough to accurately map the stream channel overlaid with the 1-meter DEM. There are instances of flow lines located on the sides of hills and even going over hills (Figure 3.5). This results in highly inaccurate output from the RBDM or even model failure. ESRI Arc Hydro is used to digitize refined, more accurate stream channels based on the MDOW Hillshade generated from the 1-meter DEMs. The updated stream channel workflow process is presented in Figure 3.6. It is important to note where bridges cross streams, the software is not able detect flow direction since it is interrupted by the higher elevation of the bridge. Therefore, the stream channel is incorrectly mapped at these locations and manually corrected.

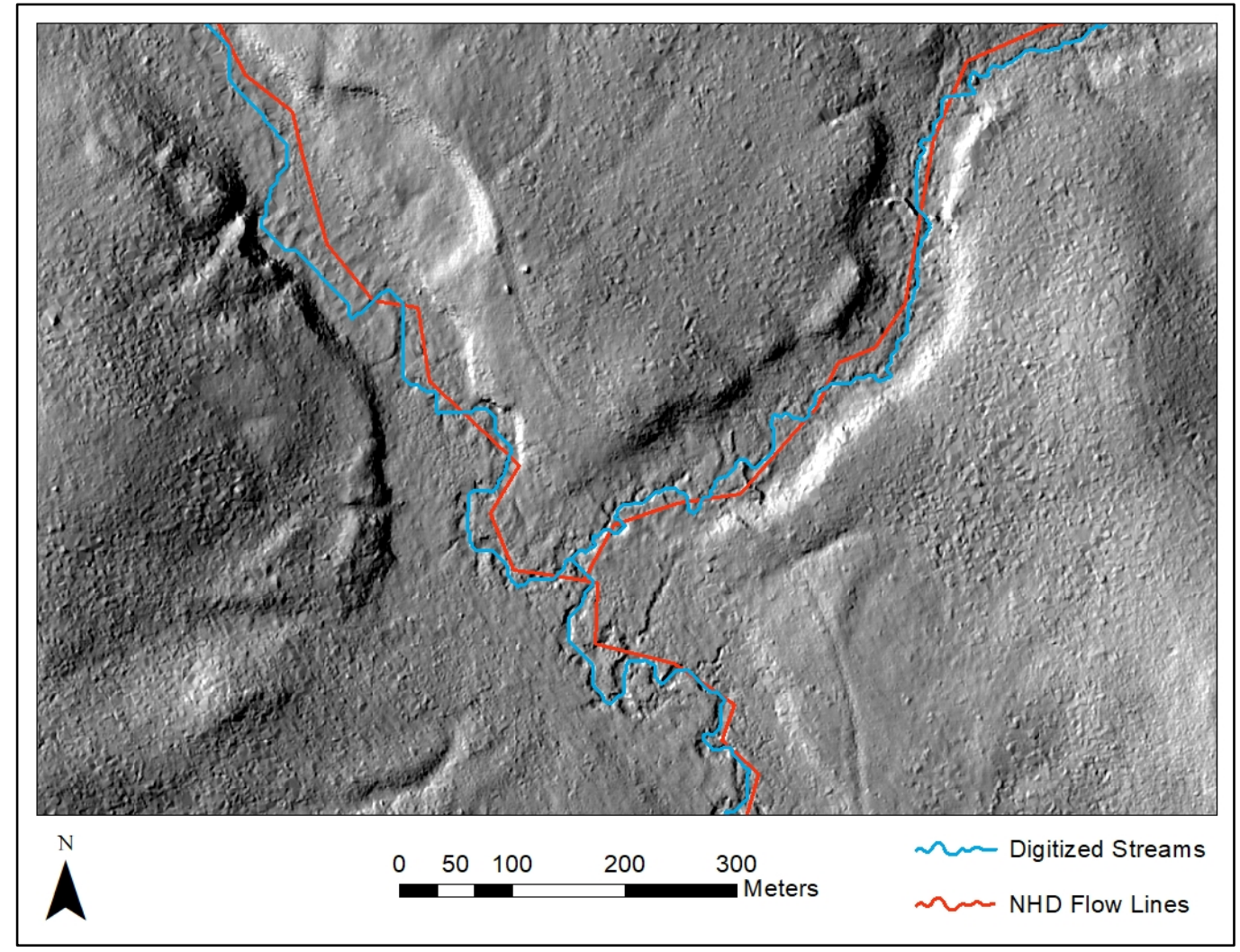

Figure 3.5. Locations of digitized stream channels and original NHD flow lines. 


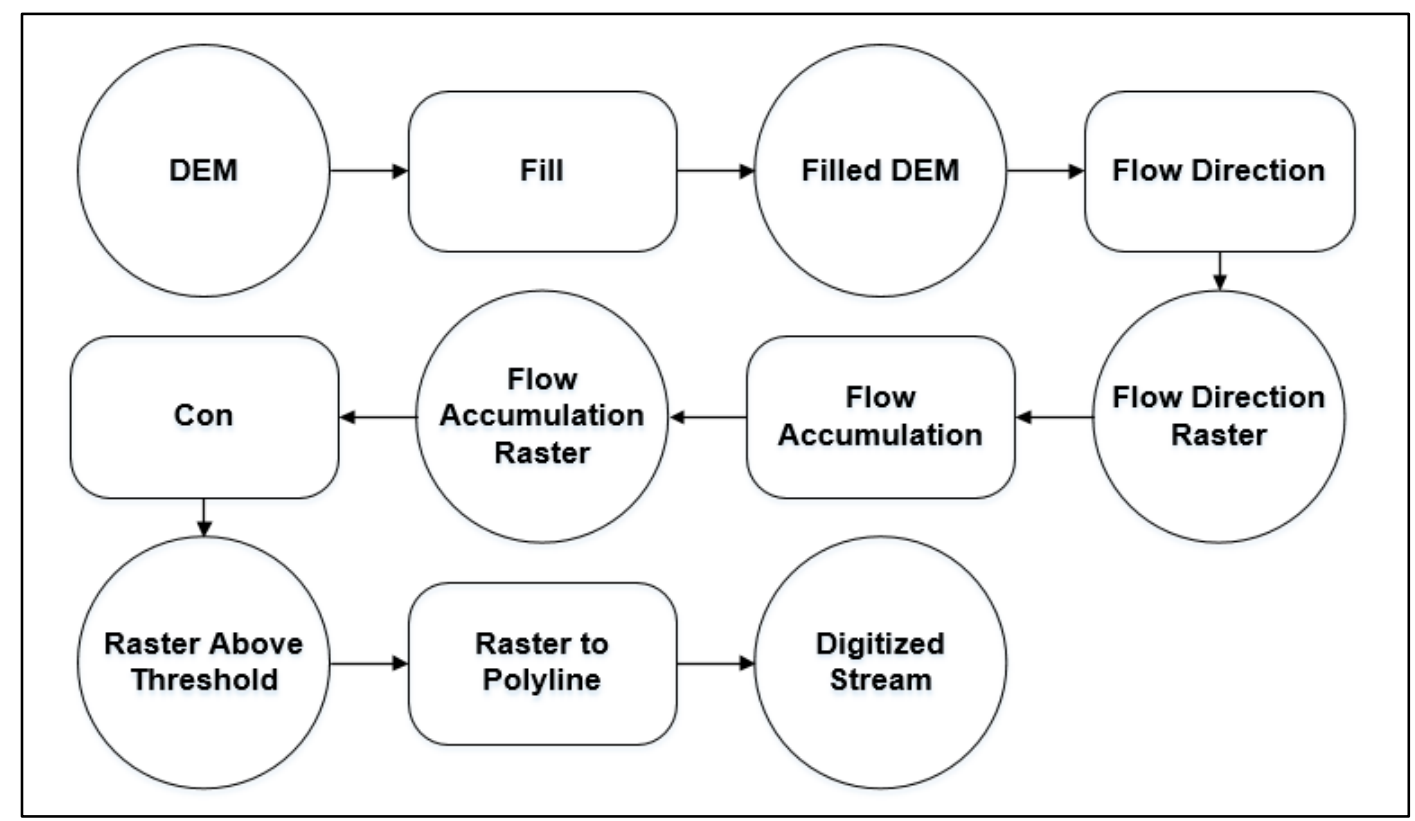

Figure 3.6. Workflow for digitizing improved stream channel locations from 1-meter DEMs using Arc Hydro tools.

Utilizing the corrected stream channels, basic variable width riparian buffer zones are delineated with the RBDM. A basic riparian area delineation uses the calculated 50-year flood height, stream channel locations and lake buffers as model inputs. Sampling distance away from the stream channel is critical for the areal extent of the 50-year floodplain to be delineated. The extent of floodplain is underestimated if an inadequate sampling distance is input. However, an excessive sampling distance requires extra computer RAM, and increases the processing time. A sampling distance of 250 meters is used for the sample watersheds based on the research completed by Abood and Maclean (2012).

Steam sample points using ground distance, rather than the planar distances used the RBDM, are calculated using a Python script (Appendix B). The sampling interval is held constant at $0.75 \%$ of the DEM spatial resolution to eliminate sample bias. The ground distance sample points are input into the RBDM as replacements for the planar coordinates. To generate the ground distance sample points, the algorithm exports all the vertices of the streams, which are defined as "point object" of polyline in Python, and their associated elevation extracted from the DEM (Figure 3.7). 


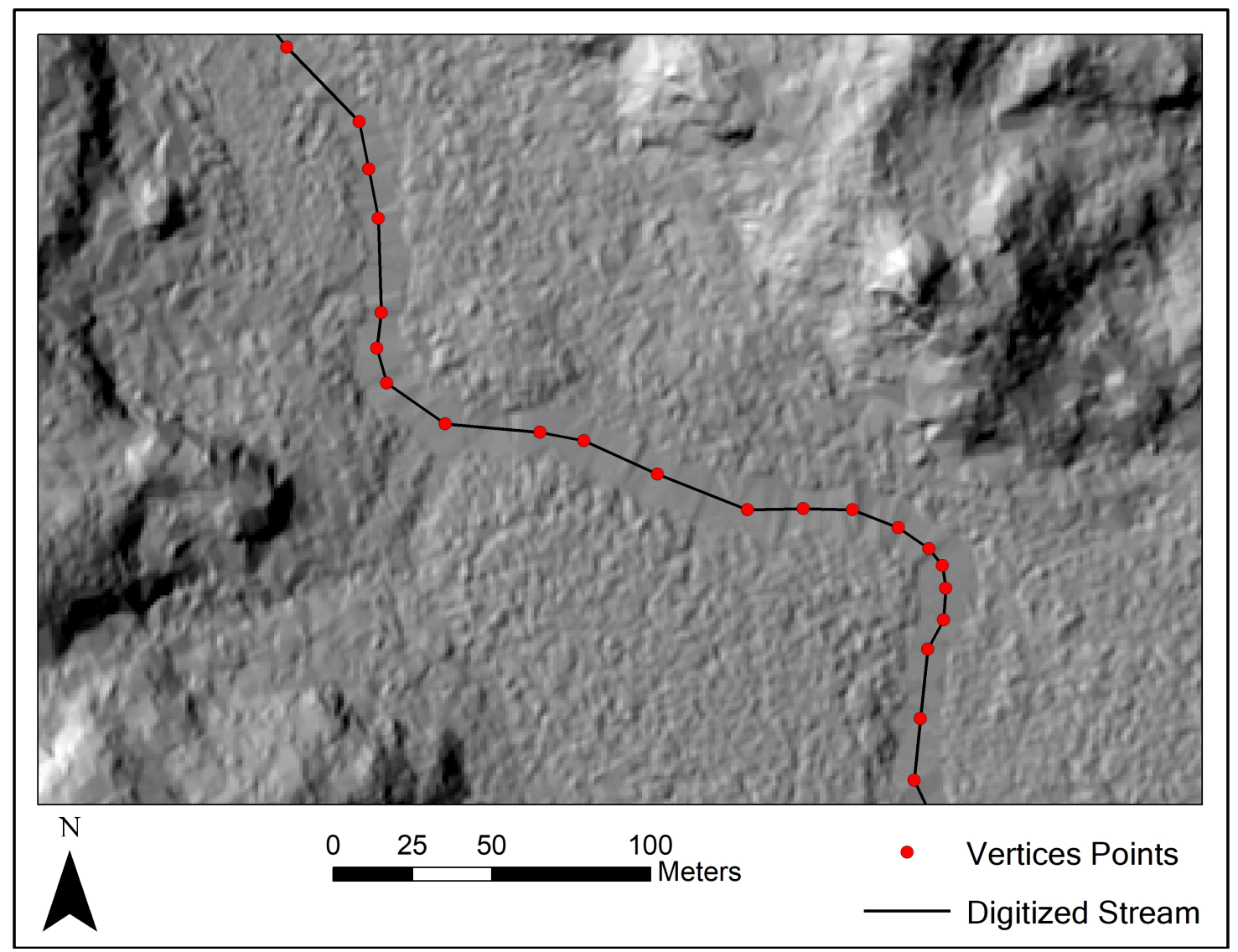

Figure 3.7. Calculated point sample locations generated along the stream.

The horizontal distance between each pair of sample points (V1 and V2) is calculated with the point's X, Y coordinates using the Pythagorean Theorem. The elevation difference is determined by subtracting the elevation of the two points. The distance between each pair of sample points is regarded as a straight line (Figure 3.8). This ground distance calculation method was selected because of the distance between the sample points relative to their small slope angles (Burkholder, 1991). The slope (degree $\theta$ ) between the points is calculated accordingly. Finally, utilizing the trigonometric function, the ground distance for each stream segment is calculated. 


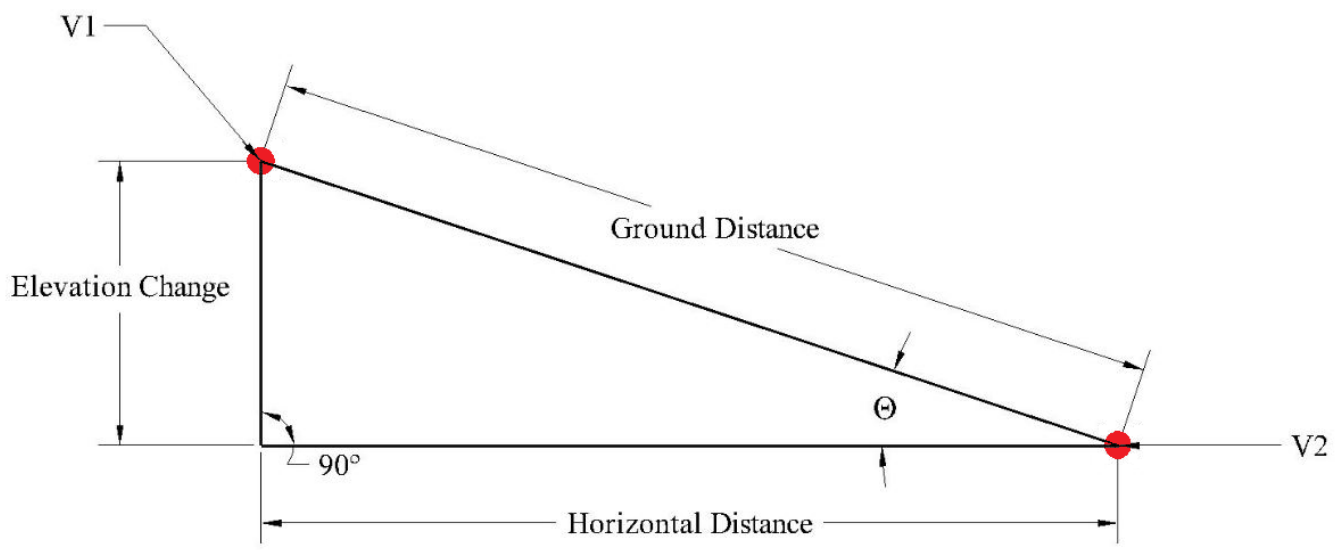

Figure 3.8. Side view of the triangular relation between adjacent points V1 and V2.

Both sampling approaches are applied to 1-meter, 5-meter, and 10-meter DEMs to determine if the spatial resolution of DEMs influences riparian buffer delineation. Hence, three pairs of riparian areas are generated in each watershed using DEMs with different spatial resolutions. The 5-meter and 10-meter DEMs are resampled from the 1-meter DEMs using bilinear interpolation. Bilinear interpolation was chosen over cubic convolution to minimize lost of subtle elevations changes.

\subsection{Analysis and Results}

As expected, the $\mathrm{X}$, Y locations of the sample ground distance points are different from the RBDM sample planar points (Figure 3.9) illustrating the impact of using a consistent ground distance sample spacing vs. planar coordinates. Basic riparian areas are delineated using the sample points from both selection methodologies. 


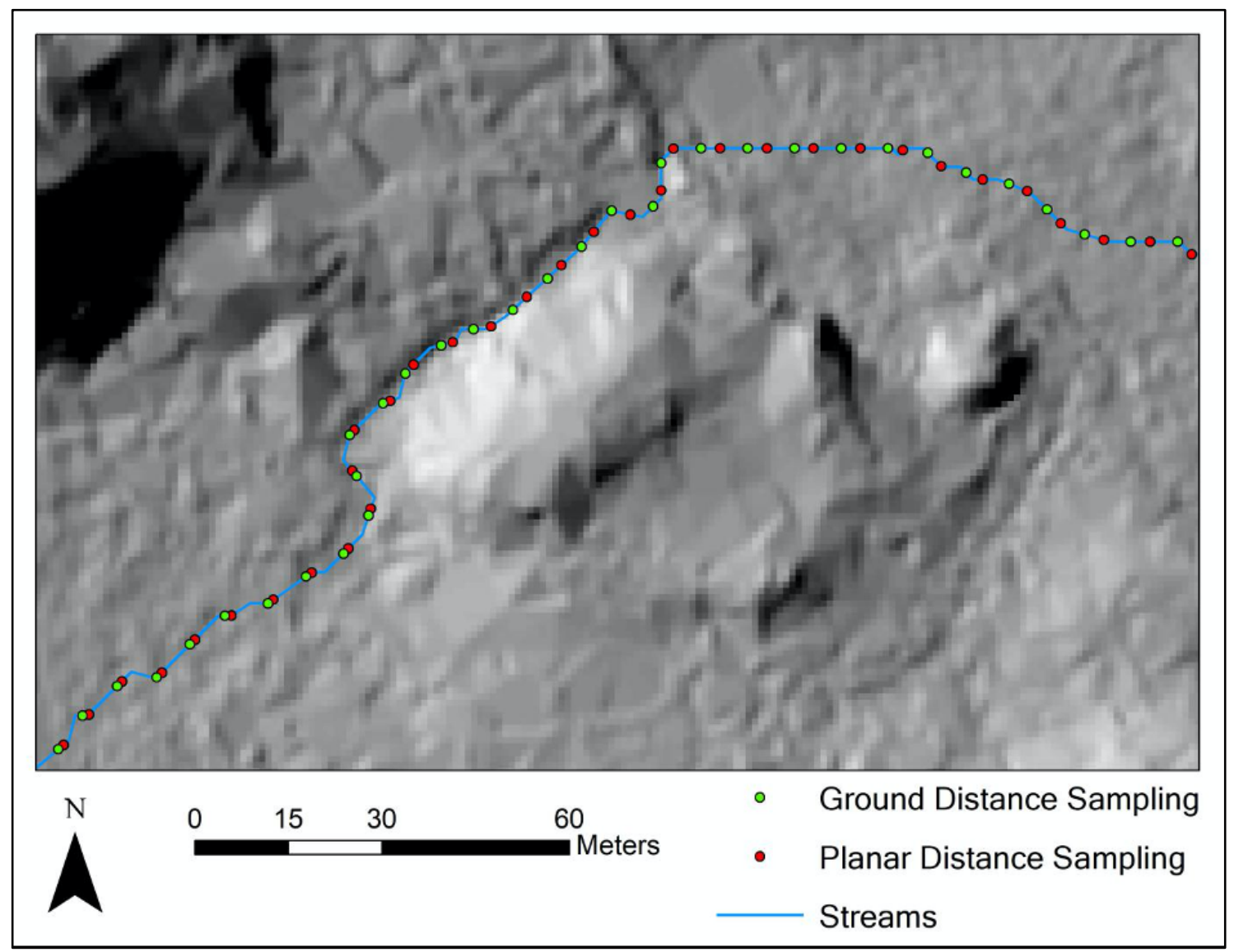

Figure 3.9. Equal interval ground distance sample points locations versus the planar sample points generated from a 10-m DEM.

Utilizing Patch Analyst (Rempel et al., 2012) landscape metrics are calculated for each riparian area to provide measures of landscape structure (i.e., composition and complexity) to assess sampling method influence on the structure and complexity of the riparian area. Patch Analyst was developed under the Spatial Ecology Program (Centre for Northern Forest Ecosystem Research), with programming support from the Thunder Bay Geomatics Service Centre, Ontario Ministry of Natural Resources, Thunder Bay, ON. It is a spatial pattern analysis extension for ArcMap and ArcGIS Pro which is freely available (http://www.cnfer.on.ca/SEP/patchanalyst/Patch5_2_Install.htm). Metrics used for this study include:

- Total Edge (TE): perimeter of the riparian buffer zone;

- Edge Density (ED): TE to the area of riparian buffer zone (Area); and

- Mean Shape Index (MSI): TE to the square root of the area and adjusted to a circular standard.

$$
\mathrm{ED}=\frac{\mathrm{TE}}{\text { Buffer Area }}
$$




$$
\text { MSI }=\frac{\text { TE }}{2 \sqrt{\text { Buffer Area } * \pi}}
$$

TE, as one of several potential calculated edge metrics, is not spatially explicit (McGarigal, 1995). Greater TE value of a riparian buffer do not necessarily represent a more complex boundary because the area of the riparian buffer is not considered. ED is spatially explicit $(\mathrm{m} / \mathrm{ha}$ ) and standardizes riparian buffer perimeter to its associated riparian buffer area. Therefore, an ED value for the riparian buffer represents boundary complexity. The MSI determines the average perimeter to area ratio and determines how circular the shape is. A smaller MSI can be interpreted as an overall smoother boundary or shape which is closest to a circle. These two metrics allow comparison between riparian areas of different sizes and contained within different landforms. In order to compare the difference on the extent of riparian areas, another parameter was derived from the output data:

- Riparian-Stream Ratio: riparian buffer area relative to stream length

The Riparian-Stream Ratio $\left(\mathrm{m}^{2} / \mathrm{m}\right)$ indicates the extent of riparian buffer around streams. A higher value means more riparian buffer exists between different stream orders for each stream segment.

The RBDM uses the calculated stream order flood height to determine the boundary of riparian area, and flood height does vary by stream orders as shown in Table 3.1. As noted previously, the riparian area around lakes is a consistent $30.38 \mathrm{~m}$. In order to focus on the sampling method influence, each output riparian area was subset by stream order, and the lake buffers are removed before analysis (Figure 3.10). The output parameters of both sampling methods with different spatial resolution DEMs are listed in Appendix C. 


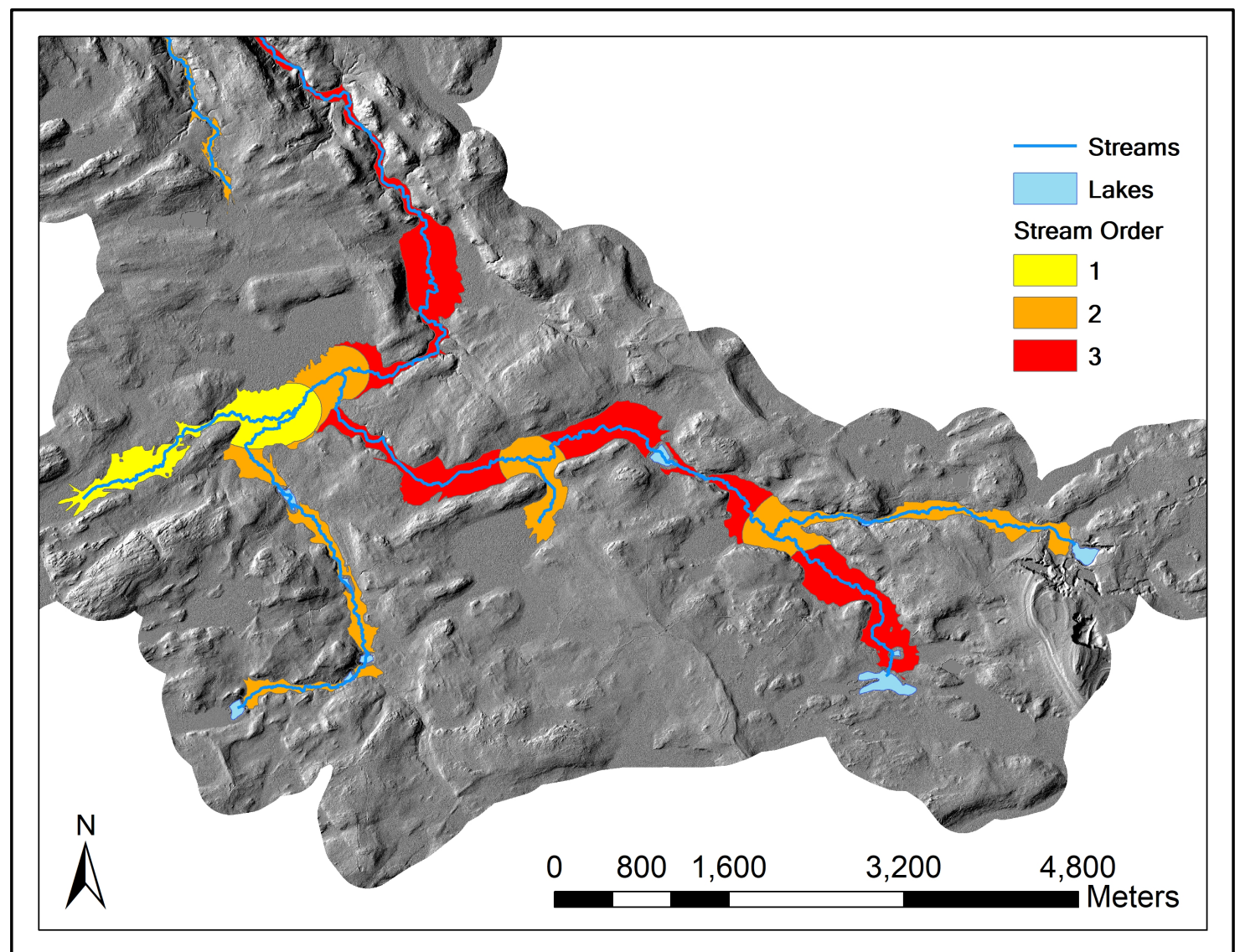

Figure 3.10. Riparian area classified by stream order excluding lake buffers.

Comparing the 2 sampling methods, the differences on ED of all stream orders are $<3$ $\mathrm{m} /$ ha when using 5-meter DEMs and $<4 \mathrm{~m} /$ ha when using 10-meter DEMs. Additionally, the MSI changes from $0 \%$ to $1.9 \%$ on 10 -meter DEMs, and from $0 \%$ to $3.7 \%$ using 5 meter DEMs. Visually, the riparian areas generated by the different sampling methods are similar as well (Figure 3.11). Another consideration is the RBDM generates riparian buffer on both sides of the stream. To represent an average difference on each side of the stream, the difference of the Riparian-Stream Ratio should be divided by two. Results indicate for each stream unit length all differences are less than the spatial resolution of the input DEMs. The RBDM's algorithm for boundary delineation indicates the overall variation between the two sampling methods are within $+/-1$ pixel. Therefore, when using 5-meter and 10-meter DEMs, the differences in shape complexity and areal extent parameters are negligible. 


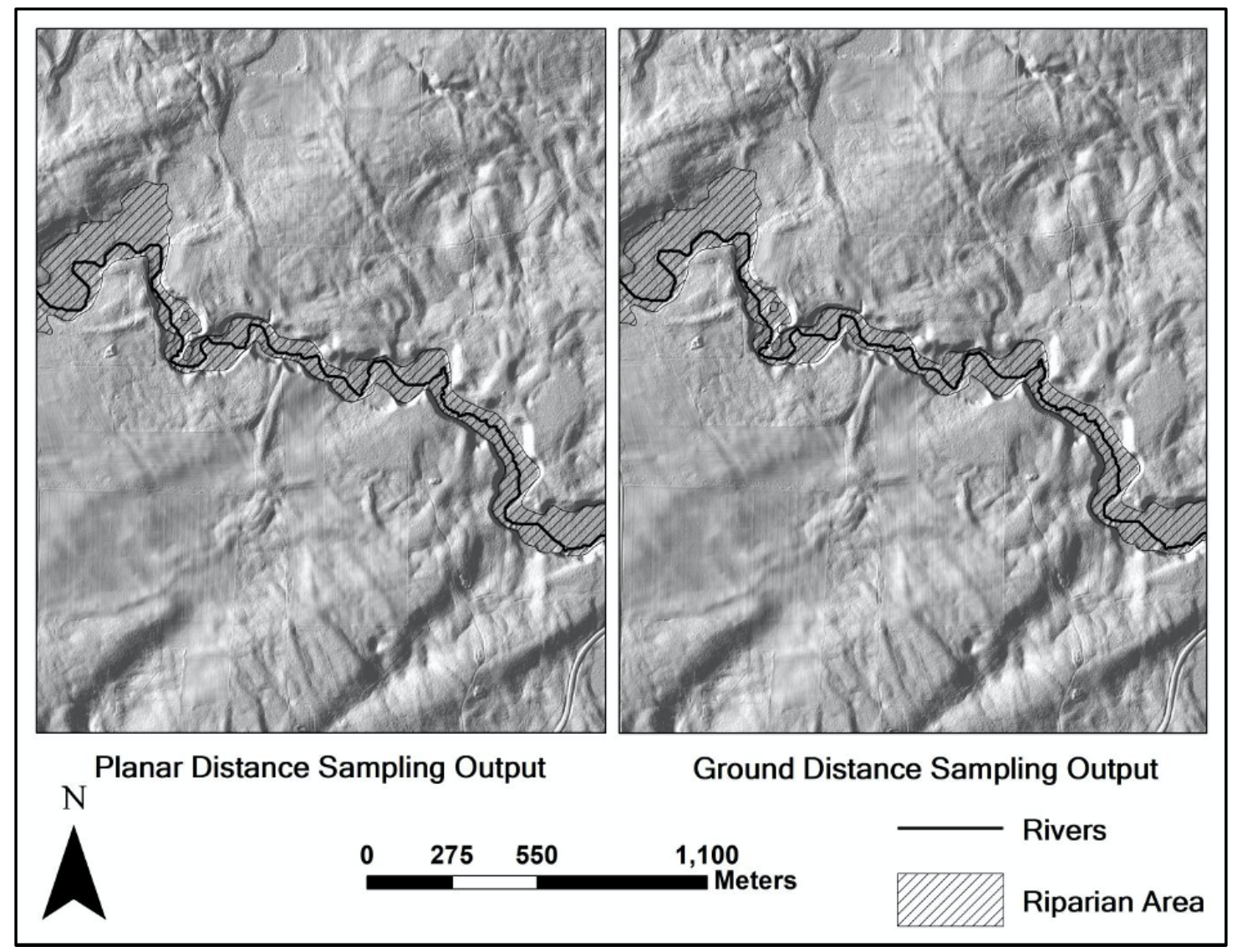

Figure 3.11. Riparian areas generated by 5-meter DEMs using both planar and equal interval ground distance sampling methods.

However, when comparing output of the two sampling methods using 1-meter DEMs, the differences are much greater. The 1-meter DEMs preserve smaller, more subtle elevation changes across the landscape. Differences in ED are up to $44.19 \mathrm{~m} / \mathrm{ha}$ when using 1meter DEMs. Using the average difference on each side of the stream using half of Riparian-Stream Ratio, the results of the new sampling method are smaller than the original sampling method, ranging from $0.06 \mathrm{~m}^{2} / \mathrm{m}$ to $10.50 \mathrm{~m}^{2} / \mathrm{m}$. The output boundary from the ground distance sampling method "shrinks" towards the stream channel compared to the planar coordinate sampling method (Figure 3.12). In addition, the boundary of the ground distance generate riparian area is more curvilinear compared to the planar coordinate riparian area boundary. According to the definitions of ED and MSI, the ground distance buffer boundary is more complex. 


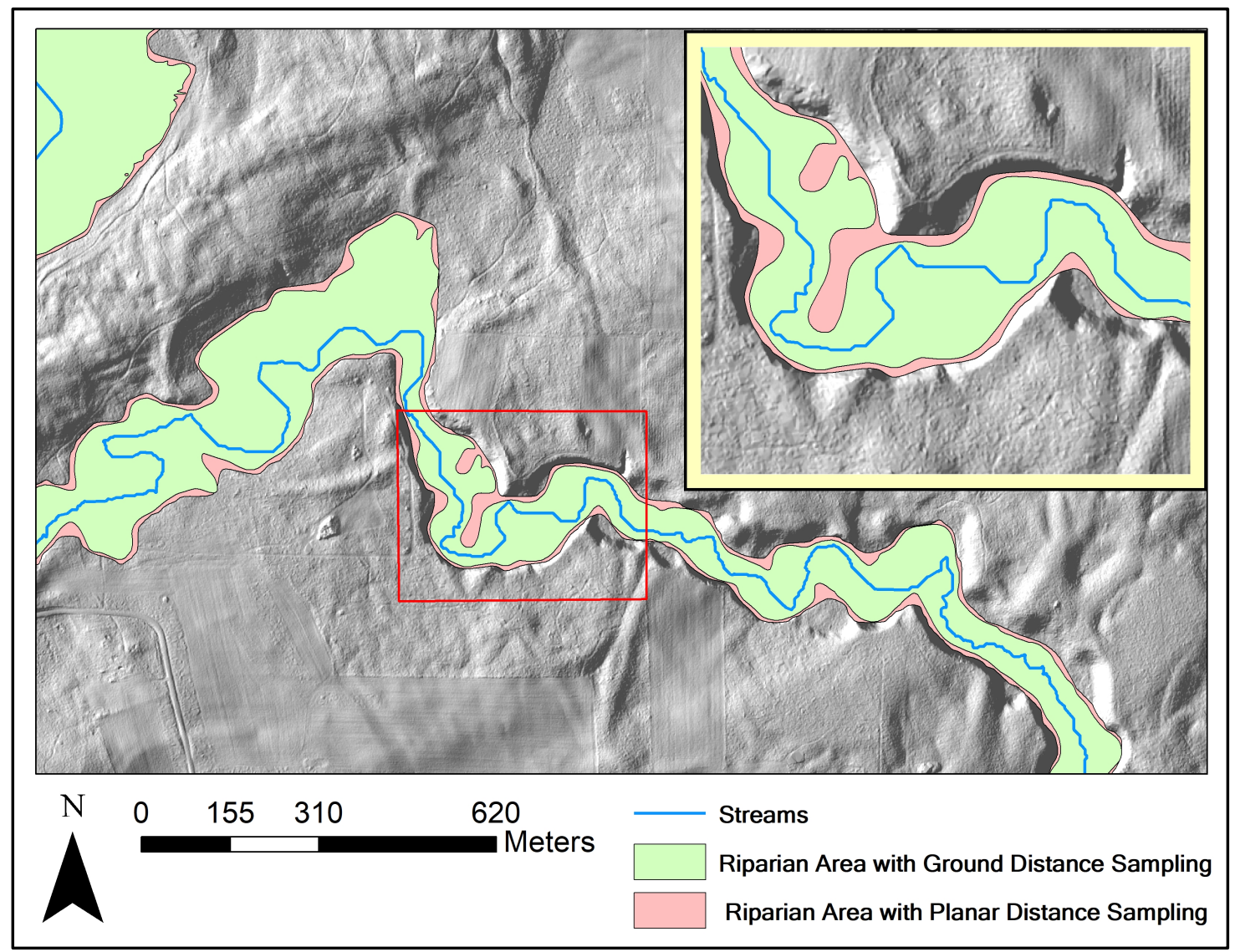

Figure 3.12. Difference between riparian area outputs between planar coordinate and ground distance sampling methods.

The riparian buffer mapped with planar coordinates and the $1 \mathrm{~m}$ DEM has a greater spatial extent with a smoother boundary shown by the pink areas in Figure 3.12. By subtracting the elevation of the stream channel from these areas reveals the elevation changes are greater than the calculated 50-year flood height for the stream order. These areas are not regarded as a basic riparian area based on the definition used by the RBDM. Reviewing the RBDM coding shows this situation is caused by the raster to vector conversion process when the riparian boundary pixels are converted to a polygon. However, the boundary is within the specified tolerance of the model, and these areas represent bias not only introduced by planar sampling approach, but the raster to vector conversion process.

The ground distance sampling method decreases this bias when using high spatial resolution DEMs. The equal ground distance interval of the sample points provides better elevation detection along the stream channel, and thus affects the transect points that are converted to the output polygon. It also explains why the ED and MSI values of the new sampling method are higher than the original sampling method in most cases.

Finally, processing time is another consideration. When executing the RBDM on computers with same configuration, processing times vary depending on the spatial 
resolution of the input DEMs and the sampling method. A higher spatial resolution DEM means more sample points are generated during the delineation process and increases the processing time and RAM cost. As noted, the number of sample points generated from the ground distance sampling method is always greater than the planar coordinate sample points. Testing the two sampling methods with the same watershed shows the processing time of the ground distance sampling method is 0.25 to 3 times longer than the planar sampling method depending on the size and complexity of the watershed and stream network.

\subsection{Conclusions and Recommendations}

A comparison between planar coordinate sampling and equal interval ground distance sampling is addressed in this research. With 5-meter and 10-meter DEMs inputs, the differences between ED and MSI for the two methods are negligible as they are within the spatial resolution of the DEM. However, using 1-meter DEMs as input where small changes in elevation are preserved does impact the placement of the basic riparian buffer boundary. The equal interval ground distance sampling provides more accurate delineation based on the selected watershed on different landforms. However, the finer scale which is larger in size requires longer processing times and higher RAM requirements.

It is recommended that further research be conducted investigating a larger number of watersheds across the available landforms. This would reduce any bias due to the small sample size used in this study. It would also permit the study of whether landform impacts the complexity and area of riparian buffers between the two sampling approaches. Additional research should be completed to determine if the areas mapped by the planar coordinate sampling method, but not the equal interval ground distance method, are included in the inclusive riparian boundary which considers contiguous areas of wetland and wet soils to the basic riparian buffer boundary.

Riparian areas are important in long term resource management for many reasons including sediment retention, nutrient trapping, critical habitat for endangered and critical flora and fauna, and wildlife movement corridors to name a few. Accurate riparian buffer area boundaries ensure protection of these critical areas, but at the same time provide resource managers with a boundary for managing adjacent land use such as agriculture and timber harvesting.

\subsection{References}

Abood, S. A., 2019. National Riparian Areas Base Map. 2019 ESRI User Conference. Paper presentation \#1361, Session: Forest Analysis \& Modeling (Thursday July 11th). 
July 8 - July 12, 2019. San Diego Convention Center.

https://storymaps.arcgis.com/stories/8cd69adaaaf541c78f8d867f0ec6b6ef

Abood, S. A., 2011. Modeling and Classifying Variable Width Riparian Zones Utilizing Digital Elevation Models, Flood Height Data, Digital Soils Data and National Wetlands Inventory: A New Approach for Riparian Zone Delineation. PhD. Dissertation, Michigan Technological University, Houghton, MI. 111 p.

Abood, S. A., and Maclean, A. L., 2018. Riparian Buffer Delineation Model for ArcPro. Version 5.1. www.riparian-solutions.

Abood, S. A., Maclean, A. L., and Mason, L. A., 2012. Modeling Riparian Zones Utilizing DEMS and Flood Height Data via GIS. Photogrammetric Engineering and Remote Sensing. 78(3): 259-269.

Albert, Dennis A., 1995. Regional landscape ecosystems of Michigan, Minnesota and Wisconsin: a working map and classification. General Technical Report NC-178. St. Paul, MN: U.S. Dept. of Agriculture, Forest Service, North Central Forest Experiment Station.

Bedient, P. B., and Huber, W. C., 2002. Hydrology and Floodplain Analysis, Third edition, Prentice Hall, New Jersey, 763 p.

Burkholder, E. F., 1991. Computation of level/horizontal distance. J. Surv. Eng., 117(3), 104-116.

Cleland, D. T., Avers, P. E., McNab, W. H., Jensen, M. E., Bailey, R. G., King, T., and Russell, W. E., 1997. National Hierarchical Framework of Ecological Units. Published in, Boyce, M. S., Haney, A., ed., 1997. Ecosystem Management Applications for Sustainable Forest and Wildlife Resources. Yale University Press, New Haven, CT. pp. 181-200.

Hanowski, J., Danz, N., and Lind, J., 2007. Breeding Bird Response to Riparian Forest Management: 9 Years Post-Harvest. Forest Ecol. Manage. 241 (2007), pp. 272-277.

Ilhardt, B. L., Verry, E. S., and Palik, B. J., 2000. Defining riparian areas. In: Verry, E.S.; Hornbeck, J.W.; Dolloff, C.A., eds. Riparian management in forests of the continental eastern United States. Boca Raton, FL: Lewis Publishers: 23-42.

Macdonald, E., Burgess, C. J., Scrimgeour, G. J., Boutin, S., Reedyk, S., and Kotak, B., 2003. Should Riparian Buffers be Part of Forest Management Based on Emulation of Natural Disturbance? Forest Ecol. Manage., 187 (2003), pp. 185-196.

McGarigal, K., 2015. FRAGSTATS: Spatial Pattern Analysis Program for Categorical Maps. UMass Landscape Ecology Lab, University of Massachusetts Amherst, Amherst, Massachusetts. 
Minnesota Department of Natural Resources, 2016. Ecological Classification System: Laurentian Mixed Forest Province. URL: https://www.dnr.state.mn.us/ecs/212/index.html

Minnesota Geospatial Information Office, 2012. LiDAR Elevation Data for Minnesota. URL: http://www.mngeo.state.mn.us/chouse/elevation/lidar.html

Palik, B., Zasada, J., and Hedman, C., 2000. Ecological Considerations for Riparian Silviculture. In Verry, E. S., Hornbeck, J. W., and Dolloff, C. A. eds. Riparian Management in Forests of the Continental Eastern United States. Lewis Publishers, New York. pp. 233-254.

Rempel, R.S., D. Kaukinen., and A.P. Carr., 2012. Patch Analyst and Patch Grid. Ontario Ministry of Natural Resources. Centre for Northern Forest Ecosystem Research, Thunder Bay, Ontario.

Riparian Science Technical Committee MN, 2007. Analysis of the Current Science behind Riparian Issues. Minnesota Forest Resources Council.

Skally, C., and Sagor, E., 2001. Comparing Riparian Management Zones to Riparian Areas in Minnesota: a Pilot Study. Minnesota Forest Resources Council, Research Report 1001.

Soil Survey Staff. The Gridded Soil Survey Geographic (gSSURGO) Database for Minnesota. United States Department of Agriculture, Natural Resources Conservation Service. Available online at https://gdg.sc.egov.usda.gov/. November 16, 2015 (FY2016 official release).

Thomas, Z., 2014. Geomorphology of Minnesota. Minnesota Department of Natural Resources.

United States Geological Survey, 2017. USGS National Hydrography Dataset. URL: http:// nhd.usgs.gov/index.html.

U. S. Fish and Wildlife Service. 2017. National Wetlands Inventory website. U.S. Department of the Interior, Fish and Wildlife Service, Washington, D.C. http://www.fws.gov/wetland/.

U.S. Geological Survey, 2016. National Water Information System data available on the World Wide Web (USGS Water Data for the Nation), accessed [June 10, 2012], at URL [http://waterdata.usgs.gov/nwis/].

United States Geological Survey (USGS), 1997. Standards for Digital Elevation Models, part I. National Mapping Program Technical Instructions, U.S. Department of Interior. 11 pp. 


\section{Conclusions}

A riparian area is a zone of interaction between aquatic and terrestrial ecosystems along streams, lakes, wetlands, and other water bodies. The zones influence water bodies and are also influenced by them thus performing important ecological functions that link aquatic and terrestrial ecosystems. Delineating accurate riparian management zones (RMZs), often utilized in Best Management Practices (BMPs) for wetlands and stream protection, is important. These zones, between waterbodies and uplands, effectively moderate microclimate at the local ecosystem scale, trap sediments and nutrient runoff from agricultural areas, and reduce soil erosion into streams.

The RBDM considers two factors that all riparian zones have in common are the watercourse and its associated floodplain, and these two components must be included in any riparian buffer delineation model. The RBDM has been used extensively by various government agencies, NGOs, academic programs, private companies, and individuals. It has undergone rigorous validation for accurate boundary delineation. Use of the model has led to additional questions about riparian area form and function. These include whether landforms and their associated characteristics influence the overall extent and complexity of riparian areas, and do topographic characteristics such as slope and elevation change influence boundary delineation with fine scale DEMs?

Using landforms resulting from extensive glaciation, watersheds were selected within each landform and riparian buffers delineated using the RBDM. In order to improve the processing accuracy, the NHD stream data was replaced with new stream data generated by Arc Hydro tools. This is necessary to take advantage of higher spatial resolution, 1 meter, DEMs. The correlations between the extent of the riparian area and the watershed extent, and the correlations between the extent of the riparian and the stream length vary from the landform types of the sample watersheds. In addition, the differences in the shape complexity of the riparian areas indicated the characteristics of each landform. The results provide an analytical perspective of the RMZs' delineation for wetlands and stream protection using geospatial data. For the BMP, geomorphic landforms and their associated landscape characters should be considered as an important environmental factor. Future research should evaluate how landforms found in other parts of the country, such as Western or Southeastern parts of the United States, impact RMZs. As long as the quality of geospatial data are guaranteed, more potential relationships between the riparian area and landforms may be discovered.

A comparison between planar coordinate sampling and equal interval ground distance sampling was evaluated in this research. Planar coordinate sampling using projected coordinated systems is the standard practice for calculating area and distance within a GIS. However, is this sampling approach adequate for quantifying and characterizing riparian buffers and what is impact of using finer spatial resolution DEMs? Coarser spatial resolution, such as a 30m DEM, does not discern subtle changes in elevation and impacts riparian area calculations. However, $1 \mathrm{~m}$ or finer spatial resolution DEMs preserve subtle and finer changes in elevation and slope. The study shows with 5-meter 
and 10-meter DEMs inputs, the differences between ED and MSI for the two methods are negligible as they are within the spatial resolution of the DEM. However, using 1-meter DEMs as input where small changes in elevation are preserved does impact the placement of the basic riparian buffer boundary. The equal interval ground distance sampling provides more accurate delineation based on the selected watershed on different landforms. However, the finer scale which is larger in size requires longer processing times and higher RAM requirements.

It is recommended that further research be conducted investigating a larger number of watersheds across the available landforms. This would reduce any bias due to the small sample size used in this study. It would also permit the study of whether landform impacts the complexity and area of riparian buffers between the two sampling approaches. Additional research should be completed to determine if the areas mapped by the planar coordinate sampling method, but not the equal interval ground distance method, are included in the inclusive riparian boundary which considers contiguous areas of wetland and wet soils to the basic riparian buffer boundary.

During the research, we found limitations which must be constantly considered. A typical problem is spatial data quality and completeness. Spatial data is constantly evolving in terms of positional accuracy and attribute detail, and various thematic layers are not updated using the same time interval which impacts the utility of the data. This study highlighted the inadequacies of the NHD data when used in conjunction with 1-meter LiDAR derived DEMs. Similar problems exist with the digital soils data.

The 50-year flood height is one of the most important inputs for the RBDM. In many areas, there are insufficient numbers of stream gauges, and for the existing gauges, not enough long-term records. This potentially leads to a biased 50 -year flood height calculation.

Riparian areas provide an important link between aquatic and terrestrial ecosystems. Increasing rates of urbanization and land use change, climate change and escalating catastrophic disasters such as fires and floods, make these areas even more critical in preventing soil erosion, preserving wildlife habitat, maintaining stream quality and reducing contamination of drinking water supplies to name a few. New and constantly evolving geospatial techniques provide more effective tools and better data to help people study and achieve environmental protection goals. 


\section{Complete Reference List}

Abood, S. A., 2019. National Riparian Areas Base Map. 2019 ESRI User Conference. Paper presentation \#1361, Session: Forest Analysis \& Modeling (Thursday July 11th). July 8 - July 12, 2019. San Diego Convention Center. https://storymaps.arcgis.com/stories/8cd69adaaaf541c78f8d867f0ec6b6ef

Abood, S. A., 2011. Modeling and Classifying Variable Width Riparian Zones Utilizing Digital Elevation Models, Flood Height Data, Digital Soils Data and National Wetlands Inventory: A New Approach for Riparian Zone Delineation. PhD. Dissertation, Michigan Technological University, Houghton, MI. 111 p.

Abood, S. A., and Maclean, A. L., 2018. Riparian Buffer Delineation Model for ArcPro. Version 5.1. www.riparian-solutions.

Abood, S. A., Maclean, A. L., and Mason, L. A., 2012. Modeling Riparian Zones Utilizing DEMS and Flood Height Data via GIS. Photogrammetric Engineering and Remote Sensing. 78(3):259-269.

Albert, Dennis A. 1995. Regional landscape ecosystems of Michigan, Minnesota and Wisconsin: a working map and classification. General Technical Report NC-178. St. Paul, MN: U.S. Dept. of Agriculture, Forest Service, North Central Forest Experiment Station.

Bedient, P.B., and Huber, W. C., 2002. Hydrology and Floodplain Analysis, Third edition, Prentice Hall, New Jersey, 763 p.

Burkholder, E. F., 1991. Computation of level/horizontal distance. J. Surv. Eng., 117(3), 104-116.

Cleland, D. T., Avers, P. E., McNab, W. H., Jensen, M. E., Bailey, R. G., King, T., and Russell, W. E., 1997. National Hierarchical Framework of Ecological Units. Published in, Boyce, M. S., Haney, A., ed., 1997. Ecosystem Management Applications for Sustainable Forest and Wildlife Resources. Yale University Press, New Haven, CT. pp. 181-200.

Cowardin, L. M., Carter, V., Golet, F. C., and LaRoe, E. T., 1979. Classification of wetlands and deepwater habitats of the United States. Washington, DC: U.S. Fish and Wildlife Service. FWS/OBS-79/31.

Ding, H., 2020. The Influence of Landforms and Sampling Approaches on Riparian Buffer Area and Complexity. PhD. Dissertation, Michigan Technological University, Houghton, MI. 87 p.

Hanowski, J., Danz, N., and Lind, J., 2007. Breeding Bird Response to Riparian Forest Management: 9 Years Post-Harvest. Forest Ecol. Manage. 241 (2007), pp. 272-277. 
Hoffman, P. F., and Bowring, S. A., 1984. Short-lived 1.9 Ga continental margin and its destruction, Wopmay Orogen, north west Canada: Geology, v. 12, p. 68-72.

Ilhardt, B. L., Verry, E. S., and Palik, B. J., 2000. Defining riparian areas. In: Verry, E.S.; Hornbeck, J.W.; Dolloff, C.A., eds. Riparian management in forests of the continental eastern United States. Boca Raton, FL: Lewis Publishers: 23-42.

Integrated Publishing. 2003. Geologic Analysis. URL: http://www.tpub.com

Jerome, D. S., 2016. Landforms of the Upper peninsula. USDA Natural Resources Conservation Service. 56 pages.

Lillesand, T. M., Kiefer, R. W., Chipman, J. W., 2015. Remote Sensing and Image Interpretation (Seventh Edition). John Wiley \& Sons, Hoboken, USA, p. 736.

Macdonald, E., Burgess, C. J., Scrimgeour, G. J., Boutin, S., Reedyk, S., and Kotak, B., 2003. Should Riparian Buffers be Part of Forest Management Based on Emulation of Natural Disturbance? Forest Ecol. Manage., 187 (2003), pp. 185-196.

Mason, L. 2007. GIS Modeling of Riparian Zones Utilizing Digital Elevation Models and Flood Height Data: An Intelligent Approach. M.S. Thesis, Michigan Technological University, Houghton, Michigan, 75p.

McGarigal, K., 2015. FRAGSTATS: Spatial Pattern Analysis Program for Categorical Maps. UMass Landscape Ecology Lab, University of Massachusetts Amherst, Amherst, Massachusetts.

Minnesota Department of Natural Resources, 2016. Ecological Classification System: Laurentian Mixed Forest Province. URL: https://www.dnr.state.mn.us/ecs/212/index.html

Minnesota Geospatial Information Office. 2012. LiDAR Elevation Data for Minnesota. URL: http://www.mngeo.state.mn.us/chouse/elevation/lidar.html

Mitsch W. J. and Gosselink J. G., 1993. Wetlands (Second Edition). New York: Van Nostrand Reinhold. 722 p.

Nelson, S. 2015. Physical Geology: Glaciers and Glaciation. Tulane University, Earth \& Environmental Science 1110.

Palik, B., Zasada, J., and Hedman, C., 2000. Ecological Considerations for Riparian Silviculture. In Verry, E. S., Hornbeck, J. W., and Dolloff, C. A. eds. Riparian Management in Forests of the Continental Eastern United States. Lewis Publishers, New York. pp. 233-254.

Peacefull, Leonard, ed. 1996. A Geography of Ohio. Kent, Ohio: Kent State University Press. 
Rempel, R.S., D. Kaukinen., and A.P. Carr., 2012. Patch Analyst and Patch Grid. Ontario Ministry of Natural Resources. Centre for Northern Forest Ecosystem Research, Thunder Bay, Ontario.

Riparian Science Technical Committee MN, 2007. Analysis of the Current Science behind Riparian Issues. Minnesota Forest Resources Council.

Schomacker, A., and Benediktsson, I. O., 2018. Chapter 6 - Supraglacial Environment. Past Glacial Environments (Second Edition), pp. 159-179.

Skally, C., and Sagor, E., 2001. Comparing Riparian Management Zones to Riparian Areas in Minnesota: a Pilot Study. Minnesota Forest Resources Council, Research Report 1001.

Soil Survey Staff. The Gridded Soil Survey Geographic (gSSURGO) Database for Minnesota. United States Department of Agriculture, Natural Resources Conservation Service. Available online at https://gdg.sc.egov.usda.gov/. November 16, 2015 (FY2016 official release).

Thomas, Z., 2014. Geomorphology of Minnesota. Minnesota Department of Natural Resources.

United States Department of Agriculture. 2017. Gridded Soil Survey Geographic Database. URL:

https://www.nrcs.usda.gov/wps/portal/nrcs/detail/tx/home/?cid=nrcs142p2_053628

United States Department of Agriculture, Natural Resources Conservation Service. Available online at https://gdg.sc.egov.usda.gov/. November 16, 2015 (FY2016 official release).

U. S. Fish and Wildlife Service. 2017. National Wetlands Inventory website. U.S. Department of the Interior, Fish and Wildlife Service, Washington, D.C. http://www.fws.gov/wetland/.

U.S. Geological Survey. 2016. National Water Information System data available on the World Wide Web (USGS Water Data for the Nation), accessed [June 10, 2012], at URL [http://waterdata.usgs.gov/nwis/].

United States Geological Survey. 2017. USGS National Hydrography Dataset. URL: http:// nhd.usgs.gov/index.html

United States Geological Survey (USGS). 1997. Standards for Digital Elevation Models, part I. National Mapping Program Technical Instructions, U.S. Department of Interior. 11 pp. 
United States Geological Survey (USGS). 2017. USGS Water Data for USA. URL: https://waterdata.usgs.gov/nwis?

Verry, E.S., Dolloff, C. A., and Manning, M. E., 2004. Riparian Ecotone: a Functional Definition and Delineation for Resource Assessment. Water, Air, and Soil Pollution: Focus, 4:67-94. 


\section{Appendix A. Sample Watersheds Raw Data}

\begin{tabular}{|c|c|c|c|c|}
\hline Landform & HUC 12 No. & $\begin{array}{c}\text { Watershed } \\
\text { Name }\end{array}$ & $\begin{array}{c}\text { Area } \\
\text { (Hectare) }\end{array}$ & $\begin{array}{l}\text { Area } \\
\text { (Acre) }\end{array}$ \\
\hline \multirow{12}{*}{$\begin{array}{l}\text { Supraglacial } \\
\text { Drift Complex }\end{array}$} & 090201030102 & Round Lake & 8418 & 20802 \\
\hline & 070101060503 & $\begin{array}{l}\text { Little Sand } \\
\text { Lake }\end{array}$ & 8391 & 20733 \\
\hline & 070101060601 & $\begin{array}{c}\text { Eleventh } \\
\text { Crow Wing } \\
\text { Lake }\end{array}$ & 6664 & 16467 \\
\hline & 070101010906 & Sugar Brook & 4493 & 11102 \\
\hline & 090300060204 & $\begin{array}{l}\text { Wagner } \\
\text { Creek }\end{array}$ & 5849 & 14454 \\
\hline & 070101020203 & $\begin{array}{l}\text { Sucker } \\
\text { Branch }\end{array}$ & 5323 & 13153 \\
\hline & 090300060402 & $\begin{array}{c}\text { Johnson } \\
\text { Creek }\end{array}$ & 5854 & 14466 \\
\hline & 090300060401 & $\begin{array}{l}\text { Headwaters } \\
\text { Rice River }\end{array}$ & 14131 & $\begin{array}{c}3491 \\
7 \\
\end{array}$ \\
\hline & 070101010202 & $\begin{array}{l}\text { Sucker } \\
\text { Brook }\end{array}$ & 5635 & 13923 \\
\hline & 090300060106 & Sand Lake & 10761 & 26590 \\
\hline & 090300060102 & Jessie Lake & 9548 & 23594 \\
\hline & 070101020301 & $\begin{array}{l}\text { Tenmile } \\
\text { Lake }\end{array}$ & 10323 & 25509 \\
\hline \multirow{8}{*}{ Igneous } & 090300010904 & $\begin{array}{c}\text { Alice Lake- } \\
\text { Kawishiwi } \\
\text { River }\end{array}$ & 9654 & 23856 \\
\hline & & Headwaters & & \\
\hline & 090300031101 & $\begin{array}{c}\text { Rat Root } \\
\text { River }\end{array}$ & 7113 & 17576 \\
\hline & 090300020402 & $\begin{array}{c}\text { Hunting } \\
\text { Shack River }\end{array}$ & 5002 & 12360 \\
\hline & 090300011304 & $\begin{array}{c}\text { Boulder } \\
\text { River }\end{array}$ & 10759 & 26585 \\
\hline & 040101010404 & Brule Lake & 8610 & 21275 \\
\hline & 090300020204 & Trout Lake & 13161 & 32521 \\
\hline & 090300012603 & $\begin{array}{c}\text { Johnson } \\
\text { River } \\
\end{array}$ & 7818 & 19319 \\
\hline \multirow[t]{2}{*}{ Metamorphic } & 090300010908 & $\begin{array}{c}\text { Kawishiwi } \\
\text { River }\end{array}$ & 4890 & 12082 \\
\hline & 090300010506 & Moose Lake & 6926 & 17114 \\
\hline Outwash & 070101060405 & Shell River & 7797 & 19266 \\
\hline
\end{tabular}




\begin{tabular}{|c|c|c|c|c|}
\hline & 070101060603 & $\begin{array}{l}\text { Big Stony } \\
\text { Lake-Crow } \\
\text { Wing River }\end{array}$ & 5451 & 13470 \\
\hline & 070101060209 & Long Lake & 6102 & 15078 \\
\hline & 070101060502 & $\begin{array}{l}\text { Big Sand } \\
\text { Lake }\end{array}$ & 6407 & 15831 \\
\hline & 070101060606 & $\begin{array}{c}\text { First Crow } \\
\text { Wing Lake- } \\
\text { Crow Wing } \\
\text { River }\end{array}$ & 4174 & 10315 \\
\hline & 070101060604 & $\begin{array}{l}\text { Wallingford } \\
\text { Creek }\end{array}$ & 6907 & 17068 \\
\hline & 070101060210 & $\begin{array}{l}\text { Fishhook } \\
\text { River }\end{array}$ & 4480 & 11071 \\
\hline & 070101050406 & Cross Lake & 2134 & 5273 \\
\hline & 070101020304 & $\begin{array}{l}\text { Big Deep } \\
\text { Lake-Boy } \\
\text { River }\end{array}$ & 5066 & 12519 \\
\hline & 070101010801 & Deer Lake & 6785 & 16766 \\
\hline \multirow[b]{3}{*}{ Peatland } & 090300050606 & Rapid River & 5938 & 14672 \\
\hline & 040102010201 & North River & 10164 & 25115 \\
\hline & 090300050101 & $\begin{array}{c}\text { Headwaters } \\
\text { Little Fork } \\
\text { River } \\
\end{array}$ & 6338 & 15660 \\
\hline \multirow{8}{*}{ Till Plain } & 090203020604 & $\begin{array}{c}\text { Upper } \\
\text { Blackduck } \\
\text { River }\end{array}$ & 8399 & 20754 \\
\hline & 090300060602 & $\begin{array}{c}\text { Pancake } \\
\text { Creek }\end{array}$ & 5304 & 13106 \\
\hline & 090300060307 & $\begin{array}{c}\text { Harrison } \\
\text { Creek-Big } \\
\text { Fork River }\end{array}$ & 6121 & 15124 \\
\hline & 070101020102 & $\begin{array}{c}\text { Bungashing } \\
\text { Creek }\end{array}$ & 7388 & 18255 \\
\hline & 040102020202 & Berry Creek & 7129 & 17615 \\
\hline & 040102010803 & $\begin{array}{c}\text { South } \\
\text { Branch } \\
\text { Whiteface } \\
\text { River }\end{array}$ & 7732 & 19107 \\
\hline & 040102020103 & $\begin{array}{c}\text { Murphy } \\
\text { Creek }\end{array}$ & 6184 & 15280 \\
\hline & 040102020201 & Wolf Creek & 8738 & 21592 \\
\hline
\end{tabular}




\section{Appendix B. Python Script}

\# Create output vertices

fclist_samplepoint $=$ infc_samplepoint

vPoints $=$ arcpy.CreateFeatureclass_management("in_memory",

"vPoints","POINT", template_samplepoint,"DISABLED","DISABLED",inWatersheds)

arcpy.AddField_management(vPoints, "streamnum", "LONG")

arcpy.AddField_management(vPoints, "streampnt", "LONG")

descSamplepoint $=$ arcpy.Describe(infc_samplepoint $)$

fs = ['SHAPE@', 'SHAPE@X', 'SHAPE@Y', streamOrder, floodData, streamType]

with arcpy.da.SearchCursor(infc_samplepoint, fs) as cursor1:

$$
\text { rowcount }=0
$$

streamnum $=0$

pnti $=$ arcpy.CreateObject("point")

fi=['SHAPE@X', 'SHAPE@Y', streamOrder, floodData, streamType, 'STREAMNUM', 'STREAMPNT']

with arcpy.da.InsertCursor(vPoints, fi) as cursor2:

$$
\text { for row1 in cursor1: }
$$

$$
\text { feature }=\operatorname{row} 1[0]
$$$$
\text { streampnt }=0
$$$$
\text { streamnum }=\text { streamnum }+1
$$

if descSamplepoint.ShapeType.lower() == "polyline": 


$$
\begin{aligned}
& \text { partcount }=\text { feature.partCount } \\
& \text { rowcount }=\text { rowcount }+1
\end{aligned}
$$

$$
\begin{aligned}
& \text { neworder }=\text { row } 1[3] \\
& \text { newflood }=\text { row } 1[4] \\
& \text { newftype }=\text { row1[5] }
\end{aligned}
$$

partnumber $=0$

while partnumber < partcount:

$$
\begin{aligned}
& \text { part }=\text { feature.getPart }(\text { partnumber }) \\
& \text { pnt }=\operatorname{next}(\text { part })
\end{aligned}
$$

while pnt:

$$
\begin{aligned}
& \text { vx }=\text { pnt.X } \\
& \text { vy }=\text { pnt. } Y \\
& \text { streampnt }=\text { streampnt }+1
\end{aligned}
$$

insertsamplepoint(vx,vy,newftype,neworder,newflood,streamnum,streampnt)

$$
\begin{gathered}
\text { pnt }=\text { next }(\text { part }) \\
\text { partnumber }=\text { partnumber }+1
\end{gathered}
$$

else:

arcpy.AddMessage("Input file must be of type polyline. $\mid n ")$

del row 1 
del cursor 1

\# Now get the elevation and slope of the vertices

\# preparing slope (degree) raster

arcpy.CheckOutExtension("Spatial")

\#rmslopeDegree = "rmslopeDegree"

arcpy.Buffer_analysis(watershedName, "in_memory/rmwatershedBuffer", "1 Kilometers", "FULL", "ROUND", "NONE", "")

inDEMsub = ExtractByMask(inDEM, "in_memory/rmwatershedBuffer")

arcpy.Slope_3d(inDEMsub, "in_memory/rmslopeDegree",

"PERCENT_RISE", "", "GEODESIC", "")

\#arcpy.Slope_3d(inDEMsub, "in_memory/rmslopeDegree", "DEGREE")

\# subset DEM and Slope rasters

rmslopeDegreesub = ExtractByMask("in_memory/rmslopeDegree", "in_memory/rmwatershedBuffer")

\#arcpy.AddMessage("Calculating elevation for sample points.....n")

inRasterList $=$ [[inDEMsub, "Elevation"],[rmslopeDegreesub, "SlopeStream"]]

ExtractMultiValuesToPoints(vPoints, inRasterList, "NONE")

arcpy.Delete_management("in_memory/rmslopeDegree", "')

arcpy.Delete_management("in_memory/rmwatershedBuffer", "')

\# cleaning the sample_points_elev from "RASTERVALU" = -9999

fields $=[$ 'Elevation' $]$

with arcpy.da.UpdateCursor(vPoints, fields) as cursor:

for row in cursor: 


$$
\begin{aligned}
& \text { if } \operatorname{row}[0]==-9999: \\
& \text { cursor.deleteRow }()
\end{aligned}
$$

del row

del cursor

\# Create output sample points

sPoints = arcpy.CreateFeatureclass_management("in_memory", "sPoints","POINT", template_samplepoint,"DISABLED","DISABLED",inWatersheds) \#rmsamplePoints \#rmsamplePOints

arcpy.AddField_management(sPoints, "streamnum", "LONG") arcpy.AddField_management(sPoints, "streampnt", "LONG") \#rmsamplePoints

\# Generate sample points by following stream segments according to stream

order

$$
\text { descSamplepoint }=\text { arcpy.Describe(infc_samplepoint })
$$

fs = ['SHAPE@', 'SHAPE@X', 'SHAPE@Y', streamOrder, floodData, streamType] \#ftype

$$
\begin{aligned}
& \text { fields }=[\text { 'SHAPE@X', 'SHAPE@Y', 'Elevation'] } \\
& \text { with arcpy.da.SearchCursor(infc_samplepoint, fs) } \\
& \text { rowcount = } 0 \\
& \text { \#for rowS in cursorS: } \\
& \text { streamnum =0 } \\
& \text { pnti = arcpy.CreateObject("point") }
\end{aligned}
$$$$
\text { with arcpy.da.SearchCursor(infc_samplepoint, fs) as cursor1: }
$$ 
$\mathrm{fi}=$ ['SHAPE@X', 'SHAPE@Y', streamOrder, floodData, streamType, 'STREAMNUM', 'STREAMPNT'] \#ftype

with arcpy.da.InsertCursor(sPoints, fi) as cursor2:

for row1 in cursor1:

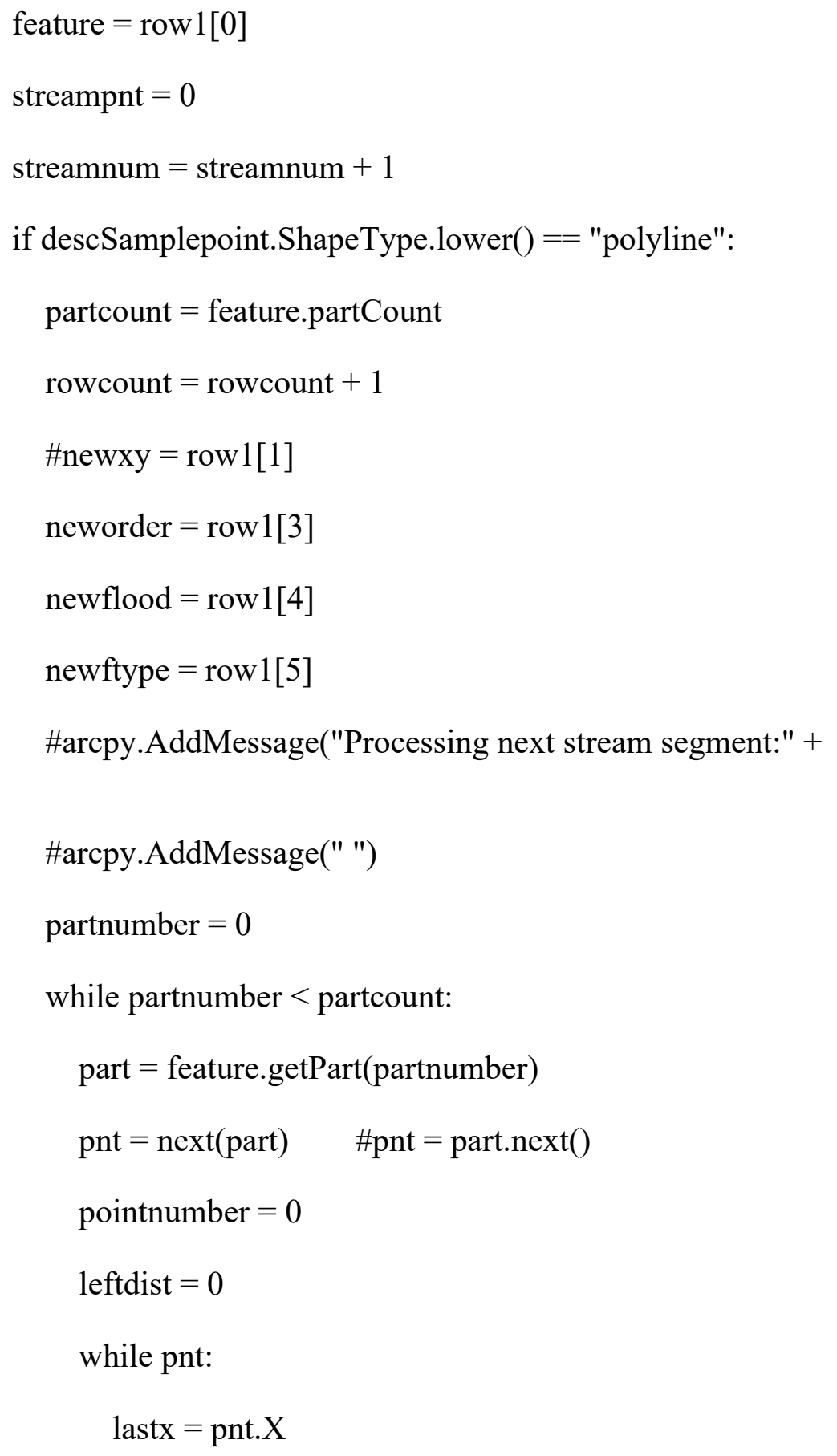




$$
\begin{aligned}
& \text { lasty }=\text { pnt.Y } \\
& \text { pnt }=\operatorname{next}(\text { part }) \# \text { pnt }=\text { part.next }() \\
& \text { if pnt: }
\end{aligned}
$$

with arcpy.da.SearchCursor(vPoints, fields) as cursor:

for row in cursor:

$$
\begin{aligned}
& \text { if row }[0]==\text { lastx and } \operatorname{row}[1]==\text { lasty: } \\
& \text { laste }=\operatorname{row}[2] \\
& \text { elif row }[0]==\text { pnt.X and } \operatorname{row}[1]==\text { pnt.Y: } \\
& \text { newe }=\operatorname{row}[2] \\
& \text { else: } \\
& \quad \text { pass }
\end{aligned}
$$

hdist $=$ CartesianDist(lastx, lasty, pnt.X, pnt.Y)

height $=\operatorname{abs}($ laste - newe $)$

$\mathrm{a}=$ math.atan(height / hdist)

dist $=$ hdist $/$ math.cos(a)

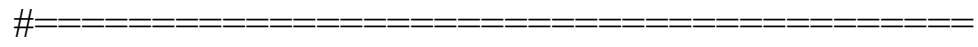

\# Calculate the sample point locations

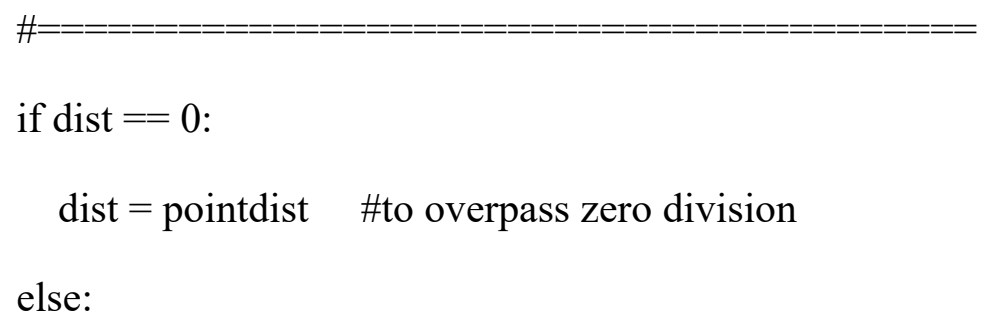

if dist $==0$ :

$$
\text { dist }=\text { pointdist } \quad \# \text { to overpass zero division }
$$

else: 
segment

$$
\begin{aligned}
& \text { pass } \\
& \text { totdist }=\text { dist } \quad \# \text { total length of segment } \\
& \text { numsamppoints }=1 \quad \text { \#number of sample points on line }
\end{aligned}
$$$$
\text { newpointratio }=((\text { pointdist*numsamppoints })-
$$

leftdist)/totdist\#pointdist is a constant based on pixel size

$$
\begin{aligned}
& \text { \#arcpy.AddMessage("Ratio " + str(newpointratio)) } \\
& \text { while (newpointratio }<=1 \text { ): } \\
& \text { \#we have enough distance to get a point in } \\
& \text { newx }=\left((\text { pnt.X }- \text { lastx })^{*} \text { newpointratio }\right)+\text { lastx } \\
& \text { newy }=((\text { pnt. } Y-\text { lasty }) * \text { newpointratio })+\text { lasty } \\
& \text { run }=\text { pnt.X - last } \mathrm{x} \\
& \text { \#\# } \\
& \text { if } \operatorname{run}==0 \text { : } \\
& \text { \#\# } \\
& \text { run }=.000000000000000000001 \\
& \text { \#slope }=(\text { pnt. Y - lasty }) / \text { run } \\
& \text { streampnt }=\text { streampnt }+1
\end{aligned}
$$

insertsamplepoint(newx,newy,newftype,neworder,newflood,streamnum,streampnt) \#newreach after newy, slope after newy

$$
\begin{aligned}
& \text { numsamppoints }=\text { numsamppoints }+1 \\
& \text { newpointratio }=((\text { pointdist*numsamppoints })-
\end{aligned}
$$

leftdist)/totdist\#pointdist is a constant based on pixel size \#use on next line segment

$$
\text { leftdist }=\text { totdist }-\left((\text { numsamppoints }-1)^{*} \text { pointdist }\right)+\text { leftdist }
$$

$$
\begin{aligned}
& \text { pointnumber }+=1 \\
& \text { \#end of while pnt } \\
& \text { partnumber }=\text { partnumber }+1
\end{aligned}
$$


else:

\#arcpy.AddMessage(" ")

arcpy.AddMessage("Input file must be of type polyline. $\mid n ")$ \#arcpy.AddMessage(" ")

in

if streampnt $==0: \quad$ \#stream segment was too short to get a point streamnum $=$ streamnum -1

del row

del row 1

del cursor

del cursor 1

arcpy.Delete_management("in_memory/rmtemstream", "') arcpy.Delete_management("in_memory/rmstreamsNOL", "") arcpy.Delete_management("in_memory/rmstreamsSelected", "') \#arcpy.Delete_management("in_memory/rmlakesWSH", "') \# End of Sample point generation section 


\section{Appendix C. Parameters under different spatial resolutions}

C.1 The parameters when using 10-m DEMs

\begin{tabular}{|c|c|c|c|c|c|c|c|}
\hline \multirow[t]{2}{*}{ Landform } & \multirow{2}{*}{$\begin{array}{l}\text { Stream } \\
\text { Order }\end{array}$} & \multicolumn{2}{|c|}{$\begin{array}{c}\text { Riparian-Stream } \\
\text { Ratio }\left(\mathbf{m}^{2} / \mathbf{m}\right) \\
\end{array}$} & \multicolumn{2}{|c|}{ ED } & \multicolumn{2}{|c|}{ MSI } \\
\hline & & Original & New & Original & New & Original & New \\
\hline \multirow{3}{*}{$\begin{array}{c}\text { Supraglacial } \\
\text { Drift } \\
\text { Complex }\end{array}$} & 4 & 91.06 & 88.95 & 94.91 & 98.15 & 6.81 & 6.92 \\
\hline & 3 & 97.14 & 94.23 & 136.72 & 140.51 & 9.38 & 9.50 \\
\hline & 2 & 67.77 & 64.82 & 61.47 & 63.12 & 7.32 & 7.46 \\
\hline \multirow{3}{*}{ Igneous } & 6 & 214.59 & 214.34 & 45.44 & 45.35 & 5.89 & 5.88 \\
\hline & 5 & 174.61 & 174.61 & 55.04 & 55.14 & 7.89 & 7.90 \\
\hline & 4 & 247.75 & 248.03 & 7.45 & 7.47 & 2.64 & 2.65 \\
\hline \multirow{3}{*}{ Metamorphic } & 5 & 49.38 & 49.34 & 1.50 & 1.50 & 1.80 & 1.80 \\
\hline & 4 & 170.60 & 171.15 & 134.39 & 134.15 & 6.37 & 6.37 \\
\hline & 3 & 166.70 & 166.73 & 39.48 & 39.54 & 4.05 & 4.07 \\
\hline \multirow{2}{*}{ Outwash } & 3 & 160.45 & 160.30 & 62.38 & 62.47 & 4.14 & 4.15 \\
\hline & 2 & 253.66 & 253.70 & 74.24 & 74.62 & 5.19 & 5.21 \\
\hline \multirow{3}{*}{ Peatland } & 7 & 95.69 & 94.93 & 48.11 & 47.78 & 6.38 & 6.38 \\
\hline & 6 & 397.27 & 396.69 & 49.98 & 50.22 & 3.95 & 3.95 \\
\hline & 5 & 581.28 & 581.26 & 13.06 & 13.09 & 1.53 & 1.53 \\
\hline \multirow{3}{*}{ Till Plain } & 7 & 244.79 & 244.67 & 37.68 & 37.79 & 6.40 & 6.42 \\
\hline & 6 & 295.58 & 295.43 & 40.09 & 40.27 & 6.93 & 6.96 \\
\hline & 5 & 333.55 & 333.62 & 11.59 & 11.60 & 3.72 & 3.73 \\
\hline
\end{tabular}




\section{C.2 The parameters when using 5-m DEMs}

\begin{tabular}{|c|c|c|c|c|c|c|c|}
\hline \multirow{2}{*}{ Landform } & \multirow{2}{*}{$\begin{array}{c}\text { Stream } \\
\text { Order }\end{array}$} & \multicolumn{2}{|c|}{$\begin{array}{c}\text { Riparian-Stream } \\
\text { Ratio }\left(\mathbf{m}^{2} / \mathbf{m}\right)\end{array}$} & \multicolumn{2}{|c|}{ ED } & \multicolumn{2}{|c|}{ MSI } \\
\hline & & Original & New & Original & New & Original & New \\
\hline \multirow{3}{*}{$\begin{array}{c}\text { Supraglacial } \\
\text { Drift } \\
\text { Complex }\end{array}$} & 4 & 80.74 & 80.86 & 115.46 & 114.04 & 7.61 & 7.54 \\
\hline & 3 & 83.35 & 83.74 & 166.55 & 165.43 & 10.67 & 10.62 \\
\hline & 2 & 55.91 & 56.56 & 73.43 & 73.18 & 8.33 & 8.29 \\
\hline \multirow{3}{*}{ Igneous } & 6 & 215.20 & 209.49 & 44.88 & 47.09 & 5.84 & 6.01 \\
\hline & 5 & 176.12 & 168.78 & 54.52 & 57.23 & 7.83 & 8.12 \\
\hline & 4 & 250.08 & 242.95 & 7.22 & 7.49 & 2.56 & 2.61 \\
\hline \multirow{3}{*}{ Metamorphic } & 5 & 8.40 & 8.25 & 0.54 & 0.55 & 1.47 & 1.49 \\
\hline & 4 & 161.06 & 161.17 & 153.49 & 152.86 & 7.00 & 6.97 \\
\hline & 3 & 149.18 & 149.14 & 41.40 & 41.64 & 4.20 & 4.22 \\
\hline \multirow{2}{*}{ Outwash } & 3 & 153.50 & 153.55 & 68.99 & 68.98 & 4.51 & 4.51 \\
\hline & 2 & 245.85 & 245.76 & 82.11 & 81.86 & 5.61 & 5.59 \\
\hline \multirow{3}{*}{ Peatland } & 7 & 79.47 & 79.72 & 52.95 & 52.87 & 7.25 & 7.23 \\
\hline & 6 & 377.58 & 377.62 & 58.13 & 57.98 & 4.39 & 4.38 \\
\hline & 5 & 572.43 & 572.55 & 14.27 & 14.20 & 1.58 & 1.57 \\
\hline \multirow{3}{*}{ Till Plain } & 7 & 233.54 & 232.88 & 42.46 & 42.58 & 7.06 & 7.09 \\
\hline & 6 & 286.03 & 283.44 & 45.69 & 45.57 & 7.70 & 7.68 \\
\hline & 5 & 320.65 & 318.81 & 13.35 & 13.33 & 4.19 & 4.19 \\
\hline
\end{tabular}




\section{C.3 The parameters when using 1-m DEMs}

\begin{tabular}{|c|c|c|c|c|c|c|c|}
\hline \multirow[t]{2}{*}{ Landform } & \multirow{2}{*}{$\begin{array}{c}\text { Stream } \\
\text { Order }\end{array}$} & \multicolumn{2}{|c|}{$\begin{array}{c}\text { Riparian-Stream } \\
\text { Ratio }\left(\mathbf{m}^{2} / \mathbf{m}\right) \\
\end{array}$} & \multicolumn{2}{|l|}{ ED } & \multicolumn{2}{|l|}{ MSI } \\
\hline & & Original & New & Original & New & Original & New \\
\hline \multirow{3}{*}{$\begin{array}{c}\text { Supraglacial } \\
\text { Drift } \\
\text { Complex }\end{array}$} & 4 & 89.49 & 75.08 & 98.49 & 132.96 & 7.09 & 8.40 \\
\hline & 3 & 96.98 & 77.22 & 142.04 & 186.23 & 9.70 & $\begin{array}{c}11.4 \\
5\end{array}$ \\
\hline & 2 & 68.60 & 50.36 & 64.47 & 79.89 & 7.59 & 8.82 \\
\hline \multirow{3}{*}{ Igneous } & 6 & 203.83 & 203.12 & 52.36 & 52.46 & 6.56 & 6.56 \\
\hline & 5 & 162.20 & 161.60 & 64.76 & 64.53 & 9.07 & 9.02 \\
\hline & 4 & 237.55 & 237.44 & 8.38 & 8.29 & 2.86 & 2.82 \\
\hline \multirow{3}{*}{ Metamorphic } & 5 & 13.20 & 0.00 & 0.87 & 0.00 & 2.05 & 0.00 \\
\hline & 4 & 175.82 & 157.75 & 133.11 & 155.57 & 6.33 & 6.96 \\
\hline & 3 & 160.13 & 138.07 & 37.08 & 44.13 & 3.95 & 4.51 \\
\hline \multirow{2}{*}{ Outwash } & 3 & 147.04 & 146.56 & 61.05 & 72.64 & 4.12 & 4.70 \\
\hline & 2 & 241.46 & 238.76 & 73.72 & 82.55 & 5.15 & 5.52 \\
\hline \multirow{3}{*}{ Peatland } & 7 & 90.16 & 73.08 & 47.18 & 55.30 & 6.36 & 7.70 \\
\hline & 6 & 392.73 & 371.74 & 50.38 & 60.25 & 3.91 & 4.47 \\
\hline & 5 & 578.51 & 567.73 & 13.18 & 15.16 & 1.52 & 1.64 \\
\hline \multirow{3}{*}{ Till Plain } & 7 & 227.35 & 226.22 & 47.65 & 48.68 & 7.92 & 8.07 \\
\hline & 6 & 281.79 & 280.25 & 48.38 & 48.68 & 8.08 & 8.10 \\
\hline & 5 & 320.32 & 317.28 & 13.80 & 13.96 & 4.27 & 4.31 \\
\hline
\end{tabular}

